DW.

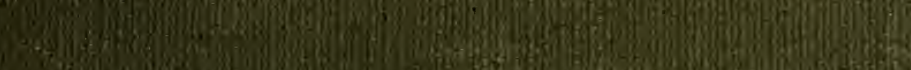

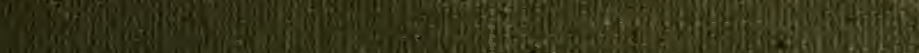

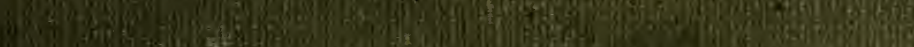

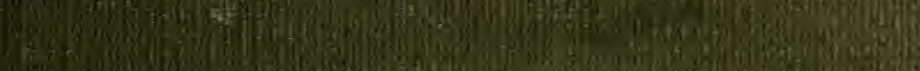

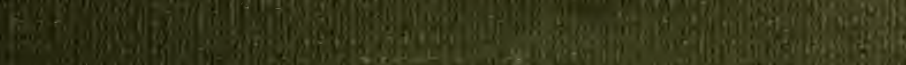

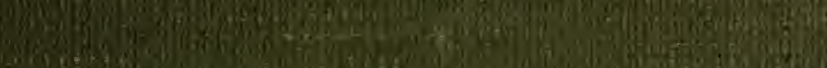

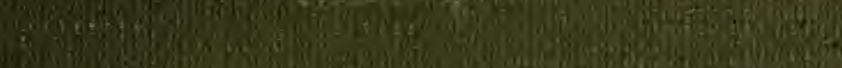

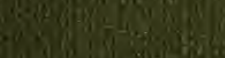

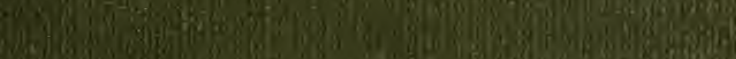

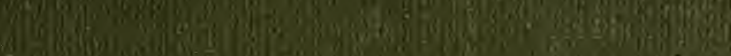

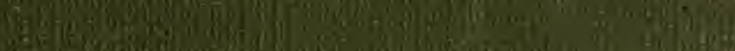

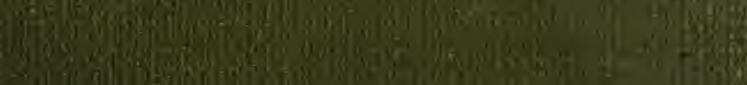

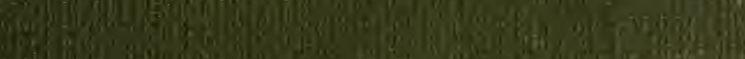 (1)

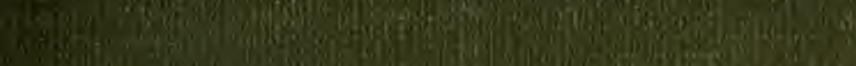




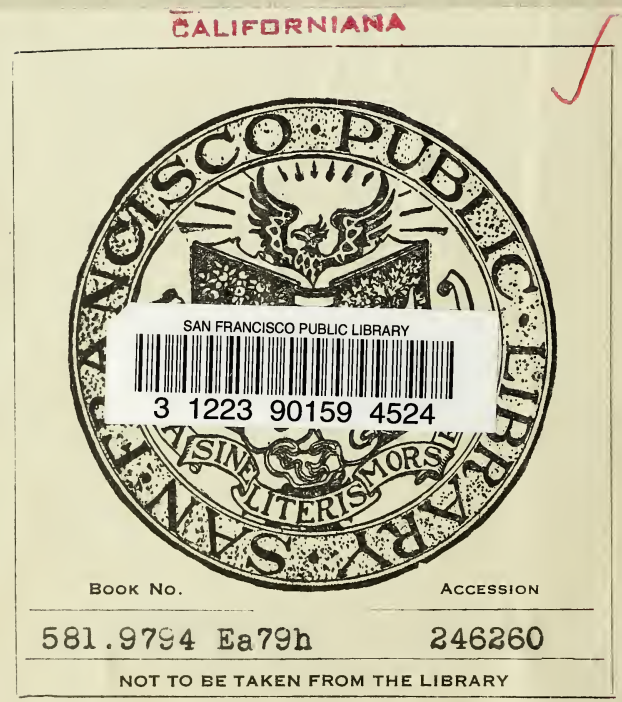

FORM NO, $375 \mathrm{M}$ 8.34 


Digitized by the Internet Archive in 2013 



\section{OCCASIONAL PAPERS}

OF THE

\section{California Academy of Sciences}

IX

\section{A Handbook of the Trees}

\section{of California}

$\mathrm{By}$

AIICE EASTWOOD

Curator of the Department of Botany

Issued July \&, 1905

SAN FRANCISCO

California Academy of Sciences 



\section{with buid regards, from Alice Sacturad \\ Occasional Papers}

OF THE

CALIFORNIA

ACADEMY OF SCIENCES

IX

SAN FRANCISCO

1905 
COMMITTEE ON PUBLICATION

Leveretr Mills Loomis, Chairman

Alpheus Bull

Joseph W. HoBson 


\title{
A \\ Handbook of the Trees of California
}

\author{
BY \\ Alice Eastwood \\ Curator of the Department of Botany
}

Issued July 8, 1905

SAN FRANCISCO

California Academy of Sciences

1905 


$$
\begin{gathered}
\times 581.9794 \\
E a 79 h \\
246260
\end{gathered}
$$




\section{PREFACE.}

The pressing need of a popular manual of the trees of California is the reason for this little book. The aim has been to prepare a work, which, while giving all the information necessary for the identification of the different trees of our valleys and mountains, will yet be so brief and concise that the entire matter can be put into a book that can be carried into the field. Fuller information concerning any tree, for instance, the value or character of its wood, structural details of its flowers and fruits, notes concerning variations, and accounts specifying all the points of distribution, can readily be obtained from other books, which are to be found in the public libraries throughout the state.

Years ago Dr. Albert Kellogg, one of the founders of the California Academy of Sciences, must have had a similar plan, for he left a great number of carefully executed drawings illustrating the different Californian trees and shrubs. It seems especially fitting that these illustrations should at last be used for the purpose for which they were designed, and as far as possible this hats been done. Without the valuable assistance of $\mathrm{Mr}$. Joseph A. Street, who not only photographed all these drawings but also made photographs of the actual specimens when there were no drawings, this book would be of much less value. I feel especially gratcoful to $\mathrm{Mr}$. Street, as his work was a labor of love-love for his art. as well as for the trees. In general these illustrations are about one-half the actual size.

The plates of the two yucas were obtained through the kindness of Dr. C. Hart Merriam and the liberality 
of the United States Department of Agriculture. The scientific names have been changed according to the late revision of the Yucceæ by Dr. William Trelease, Director of the Missouri Botanical Garden. For the picture of the California fan palm representing the trees in their native environment I am indebted to Mr. T. P. Lukens of Pasadena.

It is not easy to place the boundary between trees and shrubs, especially in California where some species are either trees or shrubs. In general a tree differs from a shrub in having a distinct trunk some distance above the ground and in being not less than fifteen feet high. Where the species is only rarely a tree and generally a shrub, it has not been included, so that many species of Ceanothus, many of the manzanitas, the sumachs, and many others have been omitted. In general I have followed Professor Charles Sprague Sargent in his selection of the trees for his magnificent 'Silva of North America'; I have also followed him in regard to nomenclature. One or two exceptions will be found, such for instance as giving the big tree the old name of Sequoia gigantea instead of Sequoia Wellingtonia.

Three keys have been arranged to make it easy to determine the species: the first according to the leaves, since many trees will be found with leaves only; the second according to the fruits, by means of which the different genera can be most readily determined; the third is a regular scientific key supposing that the material at hand is complete, with flowers, fruit, and leaves.

The few technical terms that had to be used to avoid clumsy circumlocution will be found with definitions in the index at the end of the book.

After the book was finished it was thought advisable to include the trees of Washington and Oregon, as there are 
so few of them that are not represented in California (while so many of California's trees are common to those states); they will be found in foot-notes in their appropriate places. The same plan has been followed in the case of Arizona, though in this region the trees in the mountains are quite different from those of California although their number is not great. By including these the book is made available for use throughout this wide territory, and can also be used in Nevada, and to some extent in Idaho.

Throughout the work the aim has always been brevity and clearness-the desire to help rather than to shine. 


\section{INTRODUCTION.}

The forests of the Pacific States are noted for their grandeur and extent. They are inhabited by a greater variety of cone-bearing trees than are found in any other equal area on the globe, and their trees are the largest, tallest, and oldest in the world. There are eighteen pines (Pinus), three spruces (Picea), two hemlocks (Tsuga), two Douglas spruces (Pseudotsuga), eight firs (Abies), two sequoias, one arbor-vitae (Thuya), one incense cedar (Libocedrus), seven cypresses (Cupressus and Chamaecyparis), three junipers (not including the prostrate shrub of the Sierra Nevada), and two larches (Larix) - the last found in Oregon and Washington, but not in California.

The oaks, maples, alders, birches, buckeye, sycamore, walnut, ash, and dogwood are different from their relatives in other parts of the world. We do not have magnolias, elms, lindens, beeches, hickories, chestnuts, persimmons, or mulberries, except where they have been introduced into our gardens. Here they do so well that their absence among the native trees evidently arises not so much from unsuitable environment as from lack of opportunity. We have, however, besides some of the peculiar cone-bearing trees, the incomparable madrone (Arbutus) with its magnolia-like leaves, its smooth reddish stem, its great panicles of flowers like lilies of the valley, and its beautiful clusters of crimson berries; the fragrant laurel (Umbellularia) laden in the early spring with clusters of small yellow flowers and in the fall with plum-like purple or yellow fruits; the toyon, or Christmas berry (as often a shrub as a tree), whose red berries persist on the bushes all through 
the winter; also many island and desert trees, which, while related to other species, are very distinct in appearance and generally remarkably striking.

Some of the California species of trees are singular in the limited area of distribution and the comparatively few individuals in their native homes. The Monterey cypress was originally confined to the shores of Monterey Bay but is now cultivated all over the world. The Santa Lucia fir is found in only a few cañons of the Santa Lucia Mountains in Monterey County. It is remarkable for its beauty and symmetry and the singular appearance of its cones, which are like diamondstudded birds' nests on the tops of the trees. The Torrey pine grows in San Diego County within limited areas and on the island of Santa Rosa. It has remarkably long and heavy leaves and large cones. The weeping spruce (Picea Breweriana) secretes itself in the high mountains of Trinity and Siskiyou counties in almost inaccessible regions, and is found with the same habitat in southern Oregon. It is a peculiar tree more noted for grace than for beauty, and with its drooping branches seems veiled in verdure. There are two species of Lyonothamnus, one on Santa Catalina Island and the other on San Clemente Island-beautiful and peculiar trees belonging to the Rose family. On Santa Catalina there is also a mountain mahogany (named in honor of its discoverer, Mrs. Blanche Trask) more lovely than any of its relatives in any other part of the world. It is foumil only in a few cañons so remote that until lately they had never been seen.

Some of the most important trees, however, extend throughout the mountains of the entire region-the sugar pine from British Columbia to southern C'alifornia varying in altitude with the latitude, the lowest limit ascend- 
ing as it travels south. It is common throughout the Sierra Nevada, but in the Coast Mountains is found only on the highest summits. The yellow pine and Douglas spruce are, however, the most widely distributed of all the trees, extending throughout the Rocky Mountains as well as through all the mountains of the Pacific States. The Douglas spruce reaches its greatest development in Oregon, where it is generally known as the red fir, but to the lumbermen as Oregon pine. Its tall straight stems are used extensively for masts of ships and for flag and telegraph poles. There are two species in California, the common, widely distributed species, and that with much larger cones peculiar to the southern mountains. The latter is found only on the mountains extending east and west; its relative is never found associated with it or even growing in the same mountains.

There are no real spruces (Picea) south of Trinity and Mendocino counties. Chamæcyparis reaches Mount Shasta, but is most abundant in southern Oregon near the coast. The firs are better represented in Oregon and Washington than in California, there being three species there which we do not have.

The oaks are quite widely distributed, but in general do not form forests, though some species, such as the black oak (Quercus Californica) and the white evergreen oak (Quercus chrysolepis), often grow amid the conifers. The valley oak (Quercus lobata) is the most beautiful of all the oaks and gives a picturesque park-like aspect to the great valleys where it flourishes. It always indicates fertility of soil. The Californian oaks are exceedingly variable in foliage and shape of acorns, but each species has peculiar marks by means of which it can always be distinguished, except perhaps some that grow on the islands off the coast of Santa Barbara and Los Angeles. 
The explanation for these apparent exceptions may be that they are not yet sufficiently known.

The common large-leaved maple is distributed throughout the entire region, but the vine maple is not found in southern California, nor is the mountain maple found in California, outside the Sierra Nevada.

Remarkable facts concerning the trees and forests of the region might be extended indefinitely, but sufficient have been given to show how interesting the subject is, and perhaps to incite the users of this book to a greater love for and pride in our forests, resulting in their protection from indiscriminate destruction. 
KEY TO THE TREES OF CALIFORNIA ACCORDING TO THE LEAVES.

Leaves evergreen, linear, needle-shaped, or scale-shaped; trees containing pitch or resin.

Taxaceæ, Yew Family, p. 15;

Coniferæ, Pine Family, p. 16,

Leaves simple, with entire margin.

(Larch with leaves deciduous).

Evergreen. Yucca, p. 33; oak, pp. 45-51; chinquapin, p. 51; laurel, p. 52; cherry, p. 54; mountain mahogany, p. 58; madroño, p. 74 ; manzanita, p. 75 ; lyonothamnus, p. 59 .

Deciduous. Willow, pp. 35-39; dogwood, p. 73; cherry, p. 54; desert willow, p. 78; redbud, p. 62; button-bush, p. 78 .

Leaves simple, with margins wavy, serrate, dentate, or crenate.

Evergreen. Oak, pp. 45-51; wax-myrtle, p. 41; California lilac, pp. 70-72; coffee berry, p. 69 ; madroño, p. 74; lyonothamnus, p. 59; Christmas berry, p. 57; willow, p. 38; garrya, p. 73.

Deciduous. Alder, p. 43; birch, p. 43; cottonwood, p. 40; aspen, p. 40; willow, pp. 35-39; oak, pp. 45-51; cascara sagrada or coffee berry, p. 69 ; cherry, p. 54 ; plum, p. 55; mountain mahogany, p. 58; apple, p. 56; hawthorn, p. 56; dalea, p. 60 ; hackberry, p. 52 .

Leaves lobed. Deciduous. Fremontia, p. 69; maple, p. 66; sycamore. p. 53; oak, pp. 45-51; hawthorn, p. 56.

Leaves compound. Deciduous. Hop-tree, p. 66; olneya, p. 61; walnut, p. 42; ash, pp. 76-77; box elder, p. 67; buckeye, p. 68; elder, p. 79 ; mesquite, p. 64 ; acacia, p. 65 ; parkinsonia, p. 62 ; lyonothamnus, p. 59.

Leaves fan-shaped.

Leaves sword-shaped.

Palmæ, Palm Family, p. 32. Yucceæ, Yucea Family, p. 33. 
KEY TO THE TREES OF CALIFORNIA ACCORDING TO THE FRUITS.

Seed or seeds enclosed in a fleshy covering and generally known as a berry. California nutmeg, p. 15; yew, p. 15; juniper, p. 16; palm, p. 32 ; madroño, p. 74; dogwood, p. 73; wax-myrtle, p. 41; coffee berry, p. 69 ; elder, p. 79 ; garrya, p. 73; Christmas berry, p. 57 ; manzanita, p. 75 .

Seeds in a cone. Alder, p. 43; birch, p. 43; Pine family (except the juniper), p. 16.

Seeds furnished with a tuft of cotton, in pods which are on an axis and form a catkin. Willow, p. 34; cottonwood, p. 40; aspen, p. 40.

Fruit with membranous wings or feathery tails. Maple, p. 66; box elder, p. 67 ; ash, pp. $76-77$; hop tree, p. 66 ; mountain mahogany, p. 58.

Seed in a hard woody covering and known as a nut. Buckeye, p. 68; walnut, p. 42 ; oak, pp. 45-51; chinquapin, p. 51 .

Seeds (1 or more) with a hard covering surrounded with a fleshy covering, known as a drupe or stone fruit. Cherry, p. 54; plum, p. 55; laurel, p. 52; California nutmeg, p. 15; hackberry, p. 52; hawthorn, p. 56 .

Fruit a papery core surrounded by a fleshy outer coat, and known âs a poine. Apple, p. 56.

Fruit a dry pod with 1 or several divisions.

Legume, like the pod of a bean or pea. Mesquite, p. (it; olneya, p. 61 ; parkinsonia, p. 62 ; redbud, 1) 62 ; desert willow, 1) is; dalea, p. 60; acacia, p. 65.

Pod splitting into more than 2 parts. Yuecal, p. 3i3; fremontia, p. 69; buckeye, p. 68; California lilac, pp. 70-7:2; hutton hush, p. 78; lyonothamnus, p. 5!).

Fruit in balls, 2 or more of which are strung on a pendent stem. Freatmore, p. 53. 


\section{KEY TO THE FAMILIES OF THE TREES.}

Gymnosperns. Ovules not enclosed in an ovary.

Trees or shrubs with needle-shaped, scale-shaped, or linear, generally evergreen leaves; pistillate and staminate flowers separate, on the same or different plants, without calyx or corolla, the clusters of stamens and ovules subtended by scales which in fruit become woody and form a cone, or resinous and form a berry.

Taxaceæ, Yew Family, p. 15;

Coniferæ, Pine Family, p. 16,

(The larch has deciduous leaves.)

A ngiosperms. Ovules in an ovary, with or without a calyx and corolla.

Monocotyledons. Endogens. Flowers on plan of 3, never of 5; leaves parallel-veined; woody fiber scattered through the stems in bundles with no definite arrangement.

Floral divisions greenish, 6 , in 2 dissimilar sets; ovary superior, in fruit forming a berry or stone fruit.

Palmæ, Palm Family, p. 32.

Floral divisions not green, petal-like, 6 , in 1 set; ovary superior, in fruit forming a dry pod or a fleshy fruit.

Liliaceæ, Lily Family, p. 33.

Dicotyledons. Exogens. Flowers generally on plan of 4 or 5; woody fiber forming concentric rings in the stem; leaves netted-veined.

With but one set of floral divisions.

Flowers in eatkins.

Pistillate and staminate on separate plants; 1 flower to each scale of the catkin; fruit a many seeded pod, each seed furnished with a tuft of cotton.

Salicaceæ, Willow Family, p. 34 .

Pistillate and staminate on the same plant; staminate catkins pendent; pistillate erect, cone-like, with 1-2 flowers to each scale.

Betulaceæ, Alder or Birch Family, p. 43.

Pistillate and staminate flowers on the same plant in separate catkins, sometimes in the same; catkins short, erect, with several stamens or 1 pistil to each scale.

Myricaceæ, Wax Myrtle Family, p. 41.

Pistillate and staminate flowers on the same plant, the staminate only in catkins; fruit a nut in a cup or bur. Cupuliferæ, Oak and Chestnut Family, p. 44. 
Pistillate and staminate flowers on the same plant, the staminate only in catkins, these long and pendent; fruit a nut with a rather thin outer coat.

Juglandaceæ, Walnut Family, p. 42.

Pistillate and staminate flowers on different plants, the staminate with calyx 4-parted, stamens 4; pistillate with calyx 2-lobed or wanting, ovary 1-celled, 2-ovuled, styles 2; fruit a berry.

Garryaceæ, Fringe-tree Family, p. 73.

Flowers in balls on pendent stems.

Pistillate and staminate on the same plant but on separate stems, the balls separated, 2 or more to each stem like. beads on a string.

Plantanaceæ, Sycamore Family, p. 53.

Flowers neither in catkins nor balls.

Stamens numerous, inserted on the calyx; leaves evergreen or deciduous.

Rosaceæ, Rose Family, Mountain mahogany, p. 58.

Stamens 9 in 3 sets; floral divisions 6, yellow.

Flowers in umbels; leaves aromatic.

Lauraceæ, Laurel Family, p. 52.

Pistillate and staminate flowers on separate plants, the former in pendent racemes, the latter in bunches on hair-like stems; stamens $4-5$, inserted on the receptacle; calyx minute.

Aceraceæ, Maple Family, p. 67 . Box-elder.

Stamens 5, partially united by the filaments; floral divisions 5 , large, leathery, yellow, united at base to the filaments.

Sterculiaceæ, Stereulia Family, p. 69. Fremontia.

Stamens 2, with large anthers; calyx small, 4-cleft; fruit. 1 -seeded, winged at top; pistillate and staminate flowers in panicles on separate plants.

Oleaceæ, Olive Family, p. 76 .

Ash.

Stamens and pistils in the same or separate flower's on the same plant, the former $4-5$, the latter with 2 -divided st.yles; fruit a drupe.

Celtidaceæ, Hackberry Family, p. 52. 
Calyx and corolla present, sometimes inconspicuous.

Stamens numerous, inserted on the calyx; flowers showy; fruit fleshy, either a berry or a drupe.

Rosaceæ, Rose Family, p. 54.

Hawthorn, cherry, apple, plum, etc.

Stamens 10, anthers opening by holes at the top; corolla urn-shaped.

Ericaceæ, Heather Family, p. 74.

Madroño.

Stamens 10, free; calyx and corolla of 5 separate or almost separate parts; fruit a legume.

Leguminoseæ, Pea Family, pp. 60-65.

Mesquite, acacia, parkinsonia, redbud, etc.

Stamens $3-10$ on a disk; flowers small, in racemes or corymbs; fruit of 2 parts, each winged, united at base.

Aceraceæ, Maple Family, p. 66.

Stamens 6, elongating, with reddish anthers; flowers numerous, many with imperfect pistils, in a large compound cylindrical cluster; fruit pear-shaped, pendent on long stems.

Hippocastanaceæ, Buckeye Family, p. 68.

Stamens 4-5; fruit a berry with 2-3 seeds, or a small pod with 3 seeds in 3 cells.

Rhamnaceæ, Buckthorn Family, pp. 69-72.

Cascara sagrada, California lilac.

Stamens and pistils in the same or separate flowers; sepals, petals, and stamens distinct, 4-5; the sepals often deciduous; fruit orbicular, winged all around; leaves dotted with translucent glands.

Rutaceæ, Lemon Family, p. 65.

Stamens 4-5; flowers small, in ample compound clusters; corolla monopetalous.

Caprifoliaceæ, Honeysuckle Family, p. 79. Elder-berry.

Staimens 4, divisions of calyx and corolla 4; flowers in dense globose heads on long stems; leaves opposite or in 3's.

Rubiaceæ, Madder Family, p. 78.

Button bush, button willow.

Stamens 4, sepals and petals 4, fruit a 1-seeded berry; flowers in cymes or heads.

Cornaceæ, Dogwood Family, p. 72.

Stamens 5, 1 sterile; corolla funnel-form, with a spreading 5 -lobed border; fruit a long, narrow 2-celled pod with winged seeds.

Bignoniaceæ, Catalpa Family, p. 77.

Desert willow. 


\section{CLASS I. GYMNOSPERMS.}

TAXACEE. YEW FAMILY.

Leaves linear, spreading in 2 ranks. Flowers solitary in the leaf-axils, the pistillate and staminate on separate trees. Fruit a seed surrounded by a fleshy covering, resembling a small plum or olive (Tumion), or inserted in a scarlet fleshy cup and when young resembling a tiny acorn in shape (Taxus).

Tumion Californicum Greene. California Nutueg, Torreya. Plate I, Fig. 1. Leaves bright green and glossy, 1-2 inches long, tipped with a sharp needle-like point. Seed completely surrounded by the fleshy covering, the cross-section resembling a nutmeg. Often a tall large tree 3-4 feet in diameter, but more frequently bushy especially on hills. Bark smooth, grayish brown. Blooming in spring, fruiting in fall. Fruit purple or yellowgreen. While never common and never forming forests, it is widely distributed in the Coast Mountains and throughout the Sierra Nevada at middle elevations. (Torreya Californica Torr.)

Taxus brevifolia Nutt. PACIfic YeW. Plate i, Fiti. 2. Leaves similar to the preceding but much shorter and not spiny-tipped. Seed as large as a pea, inserted in a scarlet fleshy cup which almost surrounds it. Oiten shrubby, but becoming a tree 70 feet or more high, with flaky, reddish bark and slender drooping branches. In the Coast Mountains of central and northern California and in the Sierra Nevada at middle elevations; extends northward to British Columbia. 


\section{CONIFERA. Pine Family.}

Leaves linear, awl-shaped, scale-shaped, or needleshaped. Pistils and stamens in separate flowers, sometimes on different plants. Fruit a berry or cone.

Tribe I. Leaves scale-shaped, opposite or in 3 's, imbricated and appressed. Seales of the small cone or berry opposite, few. This tribe contains juniper (Juniperus), cypress (Cupressus), arbor-vitæ (Thuya), incense cedar (Libocedrus), Port Orford cedar (Chamæcyparis). In all but the first the stamens and pistils are on the same tree.

Tribe II. Leaves either flat and 2-ranked or lanceolate, rigid, and pointed. Scales of the cone shield-shaped, spirally arranged. Seeds numerous, angled. This tribe contains the two species of Sequoia. The pistils and stamens are on the same tree.

Tribe III. Leaves separate or in fascicles, linear or needle-shaped. Scales of the cone bract-like, spirally arranged with 2 winged seeds to each scale. Stamens and pistils on the same tree. This tribe contains fir (Abies), Douglas spruce (Pseudotsuga), hemlock (Tsuga), spruce (Picea), pine (Pinus).

\section{JUNIPERUS. ${ }^{1}$ Juniper, Cendar.}

Plate II.

Leaves minute, scale-shaped, appressed and imbricated

1 Juniperus scopulorum Sargent. RED CEDAR. Spreading tree with shreddy bark and red wood. Leaves opposite, acute, blue-green. Berries blue, covered with a glaucous bloom, 2-seeded, ripening at the end of the second season. From British Columbia to Oregon; rare in the mountains of northern Arizona.

J. pachyphlæa Torr. Alligator-Bark Juniper. Low spreading tree, with thick trunk and thick bark in square plates 1-2 inches broad. Leaves opposite, blue-green. Berries reddish, containing 4 seeds. Mountains of Arizona.

J. monosperma Sargent. Low spreading tree, with shreddy bark. Leaves opposite or in 3's, gray-green. Berries dark blue or reddish, covered with a glaucous bloom, generally 1-seeded and small. In northern Arizona with the nut pine and extending southward. 
in whorls of 3's (or loosely spreading on young shoots). Fruit a globose or short-oblong resinous berry ripening the second season. Seeds bony, 1-3. Shrubs or trees branching somewhat irregularly, often low and spreading. Bark generally shreddy. Wood aromatic.

J. Californica Carr. Berry reddish, dry and resinous, globose or oblong, as large as a green pea, containing 2 seeds. Low and spreading, with short trunk. The common species of the Coast Mountains, found chiefly south of San Francisco, also on the western foothills of the Sierra Nevada on dry slopes.

J. Utahensis Lemmon. Similar to the preceding, but with finer foliage and with berries containing 1 seed. Chiefly a species of Nevada and Utah, but found in southeastern California in the desert regions.

J. occidentalis Hook. Berry blue-black, smaller than the preceding, fleshy, with 2 or sometimes 3 seeds. A low straggling bush or a fine tree irregular in outline. Grows throughout the Sierra Nevada at upper elevations; extends northeastward into Oregon and Idaho.

\section{CUPRESSUS. ${ }^{1}$ CYPRESS.}

Plate III.

Leaves opposite, minute, scale-shaped, imbricated, and appressed. Fruit a globose or oblong woody cone with thick, woody, shield-shaped scales which tit closely together before the cones open; ripening the second season but often persisting. Seeds angled, numerous.

1 Cupressus Arizonica Greene. Brunches with burk fluking off and lenving a smooth dark red surfuce. Leaves pale glunems green, generally without glamis Fruit a roundish eone, red-brown and covered with n glancous bloom, about an inch in diameter, on a short stout stalk, shield-shuped senles elevated to $u$ stout point about the midale. At upper elevations in the monntuins of Irizoma. 
C. macrocarpa Hartw. Monterey Cypress. Foliage dense, dark green. Cones numerous, clustered on short stems, generally oblong, $1-1 \frac{1}{2}$ inches long. On the shores of Monterey Bay, forming picturesque trees. Now extensively cultivated for wind-breaks and hedges.

C. Goveniana Gordon. Mountain Cypress. Foliage more spreading than in the preceding, yellow-green or glaucous, terminal branchlets slender, recurving. Cones often densely clustered, globose, an inch or less in diameter. Seeds angled, brown. Widely distributed on hills of the Coast Mountains from Mendocino County near Ukiah to San Diego County. In bloom during the rainy season.

C. pygmæa Sargent. Mendocino Cypress. Similar to the preceding but with smaller cones full of small black seeds. On the sandy plains near Mendocino City a few inches or feet high, but becoming a tree of good dimensions in more favorable localities. Apparently local on the coast of northern Mendocino County.

C. Macnabiana Murr. Fragrant Cypress. Foliage slender, very fragrant, pale bluish green, sprinkled all over with white glands. Cones small, with horn-like projections on the scales. On hillsides low and pyramidal, but near stream banks a tall tree more oblong in outline. On the inner Coast Mountains of Lake, Napa, Shasta, and adjacent counties. Blooms during the dry season.

\section{CHAM ECYPARIS. ${ }^{1}$ Lawson's Cypress, Port Orford Cedar.}

Plate IV, Fig. 1.

Leaves opposite, minute, scale-shaped, imbricated.

1 Chamæcyparis Nootkatensis Spach. This is similar to C. Lawsoniana, but has yellow staminate flowers, and the little cones have stout points on the peltate scales. The bark is not so thick and the branchlets are stouter. Grows in the mountains from Alaska to Oregon. 
Branches flat, drooping. Foliage green or glaucous. Cones numerous, globular, as large as green peas; ripening in one season; bluish, becoming brown when ripe. Seeds winged, about 4 under each scale. Blooms in spring.

C. Lawsoniana Parlat. A tall graceful pyramidal tree with fragrant wood. Staminate flowers crimson. Found in Siskiyou and Del Norte counties, but reaches its greatest development in southern Oregon. Common in cultivation. (Cupressus Lawsoniana Murr.)

\section{THUYA. ARBor-vite.}

Plate IV, Fig. 2.

Leaves minute, scale-shaped, opposite, imbricated in 4 ranks but with tips free. Branches horizontally flattened. Cones small, numerous at the ends of branchlets; ripening in one season. Scales 8-10, erect, arranged in pairs having 2-3-winged seeds at the base of all but the top and bottom pairs.

T. plicata Don. Cones half an inch or less long, soon becoming reflexed. Tall tree of pyramidal outline, sometimes becoming more than 200 feet high. Northern California near the coast; reaches its highest development farther north. (T. gigantea Nutt.)

\section{LIBOCEDRUS. INCENSE CenAR.}

\section{Plate V.}

Foliage similar to the preceding. Cones numerous near the ends of branches, not reflexed. Scales 4-6, erect, the two middle ones thick, much larger thin the others, and bearing the winged seeds at base. 
L. decurrens Torr. Tree of pyramidal outline, with reddish bark; trunk spreading at base and resembling that of the 'big tree.' In the Coast Mountains on lofty ridges and peaks and in the Sierra Nevada associated with the pines and sequoias; extends into Oregon.

\section{SEQUOIA. Redwood, Big Tree.}

Plate VI.

Leaves linear, flat, and 2-ranked, or lanceolate, rigid, and pointed. Cones oblong with shield-shaped scales, the outer part diamond-shaped and with quilted surface, spirally arranged. Seeds numerous, angled. Immense trees with enormous trunks clothed with thick red fibrous bark. Wood red.

S. gigantea Decaisne. BIG Tree. Cones as large as an egg, short-oblong, ripening in two seasons. Leaves appressed at base, rigid and pointed. This tree is famous for its great size and long life, many having lived more than a thousand years. In the Sierra Nevada from Amador to Tulare counties, growing with the white fir and sugar pines. (S. Wellingtonia Sargent.)

S. sempervirens Endl. ReDwood. Cones as large as a thimble; ripening in one season and persisting after the seeds have been discharged. Lower leaves flat, linear, 2-ranked; upper appressed at base, pointed. Forms noble forests not far from the coast from southern Oregon to San Luis Obispo County. The trees seem eternal, as new ones spring up where old ones have been destroyed. 


\section{ABIES. ${ }^{1}$ Fir.}

Plate VII.

Leaves solitary, spirally arranged but appearing 2ranked from an upward twist of the base, linear, sessile. Branches smooth with circular scars where the leaves have fallen. Leaves of lower branches horizontally spreading, the upper erect and crowded. Cones erect, generally near the top of tall pyramidal trees; the scales and seeds falling from the woody persistent axes which resemble candles on a Christmas tree. The cones are never found under the trees, only the seeds and scales.

A. grandis Lindl. White Fir. Leaves obtuse or emarginate, an inch or so long, with 2 pale bands beneath. Cones cylindrical, 2-4 inches long. Scales broad and narrow with included bracts. Becomes a fine tree sometimes 300 feet high. From Mendocino to Del Norte counties not far from the sea, extending to British Columbia.

A. ${ }^{2}$ concolor Lindl. Balsam Fir, White Fir. Leaves acute, pale green on both sides, spreading on the lower

1 Abies lasiocarpa Nutt. BALsAM. Fir. Leaves flat, grooved on upper side, rounded or notched at top, blue-green. Cones oblong-cylindrical, $2 \frac{1}{2-4}$ inehes long, lurk purple, the bracts concealed by the cone scales. High mountains of British Columbia, Washington, and Oregon. In northern Arizonn there is a species, eonsidered distinct from this, with corky bark, which has been named by 1)r. ( . Hart Merriam, Abies Arizonica.

A. amabilis Forbes. White Frr. Bark silvery white am smootl. Lенуев dark green and shining on the grooved upper surface, silvery white on lower; crowled: obtuse, acute, or notehed at tip. Cones oblong, purple, $3^{1}{ }_{2}-6$ incles long, the bracts concealed by the cone scales. Tall large tree in the mountuins of british Columbia, Washington, and Oregon.

A. nobilis Lindl. (Incorrectly ealled Lareh). Leaves flattened on the lower branches, 4-sided and grooved on the upper; rounded. acute, or notelued at tip; light blue-green. Cones oblong-cylindrical, purple or brownish, the benutiful reflexed bracts concealing the seales. Mountains of Oregon and Washingten ut midale elevations.

2 A. Lowiana Murr. (A. concolor Lowiana Le'mumu) is consideresl distinet, and the name has been applied to the tree of the high sierra vevala. It differs from the typical form in having the foliage greoner, the cones shorter, and the leaves much shorter and less spreading. 
branches, 2-3 inches long; on the upper, shorter, thicker, erect, and curving. Cones oblong-cylindrical, 3-5 inches long. Scales broad and narrow with bracts inclosed. Becomes a large tree sometimes 150 feet high with gray bark, pale yellow under the outer layer. Grows throughout the Sierra Nevada in the region of the yellow and sugar pines, extending northward to Oregon; also found in the mountains of Arizona, Nevada, etc.

A. venusta Sargent. Silver Fir, Santa Lucia Fir. FIG. 1. Leaves sharp-pointed, 1-2 inches long, glossy green on the upper surface, silvery below. Cones oval, 3-4 inches long, about 2 inches in diameter, each bract of the cone scales with a linear appendage an inch long, spreading horizontally. Found only in the Santa Lucia Mountains, from Point Sur to south of Point Gorda. Tall pyramidal tree with slender pendent apex and drooping upper limbs. (A. bracteata Nutt.)

A. magnifica Murr. Red Fir. Fig. 2. Lower leaves flat, apparently 2-ranked; upper shorter, quadrangular, crowded, curving upwards. Cones oblong-cylindrical, 6-8 inches long (bracts of the narrow cone scales included). Bark reddish brown, bright crimson under the outer layer. Throughout the Sierra Nevada at upper elevations. The variety Shastensis Lemmon has bracts of the cone scales exserted, hiding the scales in the young cones. It is found at higher elevations than the type on Mount Shasta and in the lofty peaks of Fresno, Tulare, and Kern counties near timber-line.

\section{PSEUdotsuga. Douglas Spruce.}

Plate VIII.

Leaves solitary, flat, petioled, somewhat 2-ranked by a twist at base but really spirally arranged. Cones 
maturing in one year, drooping, often persisting after the seeds have fallen, with 3 -pronged bracts conspicuously exserted over the cone scales, the middle prong longest.

P. mucronata Sudworth. Douglas Spruce, Red Fir, Oregon Pine. Fig. 1. Leaves about an inch long, bright green, rather slender, dense. Cones cylindrical, oblong, 2-4 inches long, little more than an inch in diameter, bracts straight. Bark thick, brown, fissured. Becomes a large tree 100 feet or more in height. Common in the Coast Mountains to San Luis Obispo County and in the Sierra Nevada to a little south of Yosemite. The most important source of lumber in Oregon and Washington. (P. taxifolia Britt., P. Douglasii Carr.)

P. macrocarpa Lemmon. FIG. 2. Leaves narrower than in the preceding, more acute; cones twice as large, with bracts reflexed. A large tree with immense spreading limbs. Reaches its greatest size in the mountains of San Diego County where it forms forests; also found on the mountains which run east and west from the santa Inez to the Sierra Nevada and in San Bernardino County.

TSUGA. HeMLO'K.

Plate IX.

Leaves linear, solitary, 2-ranked, petioled, and jointed

LARIX. LARCH, TAMARACK.

Leaves deciduous, short, linear, elustered in short-stemmerl tufts nlong the branchlets. Cones small, ovate or oblong, $1-2$ inches long, resemhling $n$ sprnevene, generally pendent, having a bristly appearunce from the spinc-like tips of the bracts accompanying ench cone-scale.

L. occidentalis Nutt. One of the largest trees with thick burk. Cones oblong, 1-11, inches long. Leaves 3-sided, 1-13/4 inches long, light green, stiff und puinterl. Eist of the Cascade Mountains from British (olumbin to ()regon.

L. Lyalli Parl. Small tree. The young branchlets nul huls elothed with white down. Cones $1 \frac{1}{2}-2$ inches long, the red-pnrple bruets recurving. lenves f-siled. 1-11/2 inches long, blue-green. Timber-line in the monntuins of Winshington und Oregon, and extending northwari. 
to a prominent woody base which leaves the stem rough when denuded. Cones small, drooping, maturing in one season, scales persisting on the axis.

T. heterophylla Sargent. CoAst Hemlock. Leaves thin, $\frac{1}{4}-\frac{1}{3}$ inch long, flat, obtuse. Cones less than an inch long, about as large as a thimble, numerous. Found from Mendocino County northward to Alaska, becoming 100-200 feet high.

T. Mertensiana Carr. Patton's Spruce, Sierra HemLock. Leaves $\frac{1}{2}-1$ inch long, acute at apex, attenuate at base, often curved. Cones oblong-cylindrical, 2-3 inches long, purple when young. Becomes a tall tree with spreading trunk, pendent branches, and gracefully drooping apex. In the Sierra Nevada and northward at an elevation of 7000-8000 feet; less common and smaller in the southern Sierra Nevada; extends northward to Alaska. (Tsuga Pattoniana Engelm.)

\section{PICEA. ${ }^{1}$ SPRUCE.}

Plate X.

Leaves spirally arranged but occasionally becoming 2-ranked, quadrangular, sessile, but inserted on woody projections which leave the stem rough when the leaves fall. Cones pendent from the upper branches. Scales persistent on the axis; the empty cones are always to be found under bearing trees.

P. Sitchensis Carr. Tideland Spruce. Leaves flat, slender, pointed; cones yellowish, $1 \frac{1}{2}-3$ inches long. Becomes a tall tree with thin scaly bark. The wood is valuable for butter boxes as it is without odor. An

1 Picea Engelmanni Engelm. Leaves 4-sided, blue-green, about an inch long, not stiff. Cones oblong-cylindrical, about 2 inches long, numerous on the upper branches. High mountains at upper elevations; Washington, Oregon and northern Arizona. 
important tree of the coast of northern California; abundant near Crescent City.

P. Breweriana Watson. Weeping Spruce. Leaves abruptly narrowed to an obtuse apex, flattened, about an inch long. Cones oblong-cylindrical, 2-5 inches long. A rare tree in the high mountains of Siskiyou and Trinity counties; distinguished by long pendent branches which fall over the tree like a veil. It is also found, but rarely, in the high mountains of southern Oregon.

\section{PINUS. Pine.}

Leaves needle-shaped, sheathed at base, with 1-5 needles in a sheath. Cones with woody scales persisting on the axis. Seeds winged, falling from the cone when ripe or remaining in the closed cone for years-generally until a fire sweeps over the forest or hills.

ANALYTICAL KEY, ARRANGED ACCORDING TO THE

\section{LEAVES.}

Five-Leaved. P. Lambertiana, P. monticola, P. flexilis, P. albicaulis, P. Balfouriana, P. aristata, P. Torreyana.

Four-leaved.

P. quadrifolia.

Three-Leaved.

P. ponderosa, P. Jeffreyi, P. Sabiniana, P. Coulteri, P. radiata, P. attenuata.

Two-Leaved. P. contorta, P. Murrayana, P. muricata. One-Leaved. P. monophylla.

LEAVES FIVE IN A SHEATH. ${ }^{1}$

Cone scales without prickles or knols.

Stems of cones $2-3$ inches long, erect the first year, pendent the seremil.

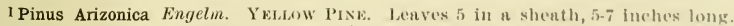
Cones oval, about 2 inches long, on short stont stems, the sertes with stemier recurved spines. Tree with stout trunk and romuled top. Mountuins of somtherm Arizona at upper elevations. 
P. monticola Dougl. White Pine, Mountain Pine, Little Sugar Pine. Plate xi, fig. 1. Leaves 2-4 inches long. Cones 5-8 inches long, cylindrical, the scales flaring backwards after the seeds are discharged and the cone fallen to the ground. Tall tree with the upper limbs or young growth pale gray, the old trunk brown with the bark in plates. At great elevations in the Sierra Nevada but at lower elevations in the northern Coast Mountains, extending northward to Washington.

P. Lambertiana Dougl. Sugar Pine. Plate Xi, FIG. 2. Leaves 3-4 inches long. Cones 1-1 $\frac{1}{2}$ feet long, cylindrical. Large tree sometimes 300 feet high, with light brown smoothish bark. A valuable timber tree which receives its popular name from the exuded resin becoming sugary on the trunk. On all the higher mountains of the Coast Range and in the Sierra at an elevation of about 5000-7000 feet. It extends northward to Oregon and Washington.

Stems of cones short or wanting, erect the first year, becoming horizontal or slightly declined the second.

P. flexilis James. White Pine. Leaves 1-2 inches long. Cones oval, 3-5 inches long, the scales spreading open when ripe. Seed with very small wing. A medium tree about 60 feet high with gray furrowed bark. Rare in California, found chiefly on the eastern slope of the Sierra Nevada; also in Oregon and Arizona.

P. albicaulis Engelm. Alpine White Pine. Plate xit, FIg 1. Leaves the same as in the preceding. Cones oval, shorter than the preceding, sessile, purple-brown, with thicker and more pointed scales. A gnarled, 1-sided tree growing at timber-line on Mount Shasta and neighboring peaks, and south to the lofty peaks of Tulare 
County, where it is replaced by $P$. Balfouriana. It extends northward to British Columbia; is also found on the mountains of Nevada and Arizona.

\section{Cone scales with prickles.}

(Sometimes the prickles are deciduous on the older cones.)

P. aristata Engelm. Foxtall Pine. Leaves 1-2 inches long. Cones ovate, 3-4 inches long with the prickles of the scales slender, recurved. Tree of medium size. Rare in California, growing on the eastern side of the Sierra Nevada and of Mount Pinos in Tentura County; extends to Arizona.

P. Balfouriana Jeffrey. Balfour's Pine, Foxtail Pine. Plate xir, fig. 2. Leaves about an inch long, rigid, curved, crowded. Cones pendulous from the ends of the

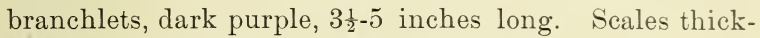
ened at the end, the prickle often short or even wanting on the old cone. Seeds with conspicuous wings. Medium tree of rugged outline. Bark deeply fissured, red-brown. Grows at or near timber-line on the high peaks and passes of the southern Sierra Nevada and on the mountains near Mount Shasta in northern California.

\section{Cone scales with thick pyramidal knobs.}

Stems an inch long, spreading or deflexerl.

P. Torreyana Parry. Torrey Pixe. Plate xill, FIG. 1. Leaves crowded at the ends of stout branchlets, thick, about a foot long. Cones broadly ovate, about 4 inches long and almost as wide at base. Sicales with at stout short beak, sometimes inflexed. reeds twice as long as the woody-based wing. Small tree with flattened top and spreading branches. Found only along the coast near San Diego and on sianta Rosil Island. 
LEAVES FOUR OR ONE IN A SHEATH.

Soft-shelled Nut Pines. ${ }^{1}$

P. quadrifolia Sudworth. Parry's Nut Pine. Leaves 1-1 $\frac{1}{2}$ inches long, generally 4 but sometimes 3 or 5 . Cones globose, about 2 inches thick, the scales forming prominent knobs. Small tree with round top. Found south of San Diego and in the San Jacinto Mountains. (P. Parryana Engelm.)

P. monophylla Torr. \& Frem. One-Leaved Pine, Nut Pine. Plate xili, fig 2. Leaves solitary in the sheath, rigid, spiny-tipped, cylindrical. Cones 1-2 inches long and almost as thick at base, with few protuberant scales. Seeds of this and the preceding are almost without wings. Small tree with irregularly spreading branches and pale foliage. Grows on dry hills in Kings and Kern River cañons, on the mountains connecting the coast with the Sierra Nevada, and especially on the eastern slope of the Sierra Nevada where the trees are abundant and the nuts form the most important article of food for the Indians. It extends to the mountains of Arizona.

LEAVES THREE IN A SHEATH. ${ }^{2}$

Cones at the ends of branchlets.

P. ponderosa Dougl. Yellow Pine. Plate xiv, FIG. 1. Leaves 5-11 inches long. Cones oval, 3-4 inches long, almost sessile. Scales thick, slightly knobbed, with a straight prickle. Tall tree with red-brown bark in

\footnotetext{
1 Pinus edulis Engelm. Nut PINe, PIÑon. Leaves 2-3 in a sheath, stiff and pointed, about an inch long. Cones and seeds similar to $P$. monophylla. Low tree with short trunk and spreading branches. Arizona, eastward and north on plateaus, forming forests.

2 P. Chihuahuana Engelm. Leaves 3 in a sheath, slender, pale green, 21/2-4 inches long. Cones broadly ovate, $1 \frac{1}{2}-2$ inches long, the scales with small recurved prickles that fall soon. Mountains of southern Arizona.
} 
large plates. One of the most important timber trees. Widely distributed through the Coast Mountains at upper elevations and in the Sierra Nevada associated with the sugar pine. The form in Arizona has been called P. latifolia Sargent.

P. Jeffreyi Murr. Plate xiv, fig. 2. This is considered by some of the best authorities to be a variety of the preceding. The bark is darker, cones are much larger, and leaves shorter. It grows at greater elevations.

\section{Cones lateral.}

(The branch grows out beyond them.)

Scales armed with stout claws.

Hard-shelled Nut Pines.

P. Sabiniana Dougl. Digger Pine, Nut Pine, Grayleaf Pine. Plate xv. Leaves slender, drooping, light green or glaucous, foot long. Cones short-oval, large, 6-10 inches long, 4-6 inches in diameter, the heary scales armed with hooked claws, the stems stout, $1 \frac{1}{2}$ inches long. A picturesque tree with open spreading branches. Common in the hot interior valleys of the Coast Mountains and in the foothill region of the Sierra Nevada and the San Bernardino mountains. The nut forms a most. important article of food among the Digger Indians.

P. Coulteri Don. Coulter's Pine, Bull Pine, Bigcone Pine. Plate xvi. Leaves crowded at the ends of the branchlets, stiff, bright green, $\frac{1}{2}-1$ foot long. Cones on short stems, long-oval, pointed, 10-1t inches long, 4-5 inches in diameter; scales with a stout sharp claw strongly curved, an inch or more long. In this and the four preceding the cones persist on the trees some time after the seeds have been discharged and when they fall leave the lower scales attached to the stem, which persists 
for some time. On high ridges and peaks of the Coast Mountains from Mount Diablo south; also on the mountains of southern California.

Cones oblique, whorled, scales knob-like, armed with prickles.

P. radiata Don. Monterey Pine. Plate xvit, fig. 1. Leaves crowded, slender, dark green, 4-6 inches long, closely serrate. Cones in whorls deflexed on short stems, obliquely short-oval, pointed. Scales on the outer side thick, mound-shaped, much larger than the flatter inner ones. Tree with spreading branches and brown fissured bark. Common on the coast of Monterey Bay and extending somewhat to the north. Common in cultivation. (P. insignis Dougl.)

P. attenuata Lemmon. Scrub Pine, Knob-cone Pine. Plate xvir, fig. 2. Leaves 3-7 inches long, slightly serrulate. Cones in whorls of 2 to many, persisting closed on the tree until after a fire, strongly reflexed on short stems, 3-5 inches long, pointed, oblique. Scales thick and conical on the outer side, almost flat on the inner, all with sharp prickles. Small tree, loosely branched, with thin, light brown bark. It bears cones when a foot or so high. Common in the hills of the Coast Mountains and in the foothills of the Sierra Nevada; extends northward. (P. tuberculata Gordon.)

LEAVES TWO IN A SHEATH.

Cones at ends of branchlets; scales of cone knob-like, armed with prickles.

P. contorta Dougl. Scrub Pine. Plate xvir, fig. 3. Leaves 1-1 $\frac{1}{2}$ inches long, slender. Cones oblique, clustered in whorls or single, 1-2 inches long. Scales with prominent knobs each tipped with a fine prickle; sometimes remaining closed until after a fire. Small tree 
with spreading branches and rounded or depressed top. Along the coast near swamps in northern California and on dry hills inland. On the sandy barrens near Mendocino City the trees bear cones when only a few inches high. Extends northward.

P. Murrayana Murr. Tamarack Pine, Lodge-Pole Pine. Plate xvir, Fig. 4. Leaves thick, about 2 inches long, serrulate. Cones small, slightly oblique, opening at maturity and soon falling. Tall slender tree with smooth, straight, light brown trunk. Common on the borders of mountain streams, meadows, and lakes in the Sierra Nevada at upper elevations; widely distributed in the mountains northward and eastward.

Cones lateral, rarely subterminal.

P. muricata Don. Coast Pine, Bishop Pine. Plate XVII, FIG. 5. Leaves stiff, strongly serrulate, 4-6 inches long, dense. Cones oblique, whorled, sessile, recurved, spreading, 2-3 inches long; often remaining closed many years and persisting after opening even on the main. trunks of large trees. Scales knob-like, tipped with stout spines turning toward the base of the cone on the outer scales. Tree of medium size, with spreading branches, flat top, reddish bark. Along the coast from northern California to San Luis Obispo. There are fine groves along Tomales Bay in Marin County and on the hills and cañons rising therefrom. 


\section{CLASS II. ANGIOSPERMS.}

\section{Monocotyledonous Plants. Endogens.}

Stems with woody fiber scattered, never arranged in rings. Flowers usually with the parts 3 or some multiple of 3 . Leaves generally parallel-veined.

Divisions of the flower 6 , greenish, in 2 dissimilar sets. Ovary superior, in fruit forming a berry or stone fruit.

Palm Family.

Divisions of the flower 6 in 1 set, all petal-like. Ovary superior, in fruit forming a dry pod with 3 divisions, or becoming fleshy.

Lily Fayily.

\section{PALME. Palm Family.}

Stems simple, the leaves forming a crown at summit, pinnately divided, or circular and fan-shaped with stout petioles sheathing the stem and often persistent on the trunk. Flowers small, sessile, on a simple or branched axillary stem, which is at first enveloped in a leaf that falls off; outer divisions of the flower united, forming a cup, folding over each other in the bud, the inner meeting by the edges in the bud; stamens shorter than the floral divisions. Ovary 3-celled or of 3 distinct carpels. Stigmas short or wanting.

Washingtonia filamentosa $O . K$. Washington's Palm, California Fan Palm. Plate xviti. Twenty to 40 feet high. Trunk 1-3 feet in diameter, covered with the persistent bases and shields of dead leaves. Leaves fanshaped, circular, 3-5 feet in diameter, the divisions extending to the middle, margined by fine elongated fibers. Petioles stout, smooth, 2-5 feet long, 1-3 inches broad at summit, margined with stout hooked spines. Flowering stems 8-10 feet long. Fruit black when ripe, 
$\frac{1}{3}$ inch in diameter, with sweet pulp. Native of San Bernardino and Riverside counties, but cultivated throughout California, particularly in the southern part of the state.

\section{LILIACEe. Lily Family.}

Stems simple or branched. Divisions of the flower all alike and resembling petals. Ovary superior. Stamens 6. The only native trees of this family are the yuccas. Cordyline, or as it is called Dracæna or dragon palm, is better known throughout California, being extensively cultivated.

\section{YUCCEA.}

Divisions of the flower thick, curved inwards; style wanting.

Cleistoyucca, Tree Yucca, Josua Tree.

Divisions of the flower thin, spreading at night; style evident. Yucca, Spanish Dagger.

Cleistoyucca arborescens Trelease. Tree Yucca, Josua Tree. Plate xix. Widely branching, becoming 30 40 feet high. Rough gray bark. Leaves densely crowded at the ends of the branchlets, stiff and dagger-like, tapering from a dilated base, 5-6 inches long, bluish green, margins minutely serrulate but without thread-like filitments. Flowers in large sessile panicles, greenish white, globose, densely clustered, the almost distinct divisions curved inwards; filaments thick; anthers arrow-shaped. Ovary egg-shaped, tapering to a sessile star-shaped stigmal. Fruit a dry pod, spongy, with papery core, not splitting open when ripe but scattered by the wind over the desert. Common on the Mohave Desert and the valleys and hills branching therefrom.

Yucca Mohavensis Sargent. Spanish Bayonet, Tree Yucca. Plate xx. Fifteen feet or less in height, simple or with short branches at top. Trunk with dark 
brown bark, or often clothed with leaves to the base and surrounded with smaller stems. Leaves yellowish green, about 2 feet long, 3 inches wide at base, abruptly tapering to the lanceolate blade, which is strongly incurved at the dagger-like tip, and with threads along the margins. Flowers in dense heavy panicles, $1-1 \frac{1}{2}$ feet long, on very short peduncles; flowers 1-2 inches long, cream-color tinged with purple, with short stems at first erect, later pendent; stamens with hairy filament. Ovary sessile, narrowed to a short style; 3-lobed stigma with notched divisions. Fruit drooping, 3-4 inches long, $1 \frac{1}{2}$ inches thick, constricted near the middle, becoming purple or black when ripe, with sweet succulent pulp half an inch thick. Near San Diego, Mohave Desert, San Bernardino and San Jacinto mountains.

\section{Dicotyledonous Plants. Exogens.}

Stems with woody fiber arranged in rings. Parts of the flowers 4 or 5 or some multiple of those numbers. Leaves netted-veined.

\section{SALICACER. WILLOW FAMILy.}

Trees or shrubs with deciduous leaves. Staminate and pistillate flowers in catkins and on separate trees; calyx and corolla wanting. Fruit a 1-celled pod containing numerous seeds, each provided with a tuft of silky down (commonly called cotton) by means of which they are transported by the wind.

\section{SALIX. WILLOW.}

\section{Plate XXI.}

Leaves generally long and pointed, stipules usually present on young shoots, generally disappearing from 
the older leaves. Stamens 1-6 to each scale of the staminate catkin, the filaments often united at base, anthers yellow. Pods small, ovate, pointed, splitting from the top into 2 parts. Buds covered with scales, which fall as the catkins expand and are then generally called 'pussies.'

\section{KEY TO THE WILLOWS.}

CATKINS ON SHORT LEAFY BRANCHLETS APPEARING WITH THE LEANES.

Leaves lanceolate, tapering at top, serrate.

Leaf-stalks without glands.

Leaves narrowly lanceolate, bright green on both sides.

Paler on lower side.

S. nigra.

Teeth incurved.

S. occidentalis.

Teeth rounded.

S. Mackenziana.

Leaves ovate-lanceolate, paler on lower side.

Teeth obscure.

S. 1ævigata.

Teeth gland-tipped.

S. amygdaloides.

Leaf-stalks with glands.

S. lasiandra.

Leaves long and narrow linear to lanceolate, entire or finely and sparsely toothed, smooth to white downy on both sides.

Pods with large sessile stigmas.

S. fluviatilis.

Pods with linear, lobed stigmas.

S. sessilifolia.

Leaves short and narrow, apparently in 2 ranks.

S. taxifolia.

Leaves evergreen, lower surface silvery white, upper yellowish green:

S. Bonplandiana.

CATKINS APPEARING BEFORE THE LEAVES.

(Generally sessile or on very short stems.)

Leaves broadest toward the top, paler and often densely woolly on the

Catkins long, generally erect.

lower side.

Pods smooth; stamens 2, united.

S. lasiolepis.

Pods downy; stamens 2, separate.

S. Hookeriana.

Pods white-woolly; stamens 1 or rarely 2.

S. Sitchensis.

Catkins short, often recurving; pods downy; stamens 2, united.

S. Nuttallii brachystachys.

Salix nigra Marsh. BLACK WiLLow. Trunk very dark, generally leaning over streams. Leaves narrowly lanceolate, sometimes curved, $4-6$ inches long, $\frac{1}{4}-\frac{1}{3}$ inch wide, 
narrowed to a long point, closely serrate, smooth and bright green on both sides. Catkins on leafy branchlets, the staminate with 3-5 stamens on each scale, the pistillate with tawny pods on short pedicels, the styles short and stigmas notched. Along the San Joaquin and Sacramento rivers and their tributaries, chiefly in bottom lands; extends into eastern Oregon and Arizona. The variety vallicola Dudley is the form common in California south of Tehachapi. It is the largest willow in that section and is common along streams.

S. occidentalis Koch. Small tree with dark brown deeply fissured bark. The young branches are downy, becoming brownish. Leaves lanceolate, tapering to a long slender point, serrate, 2-6 inches long, woolly when young but becoming bright green and glossy on the upper surface, silvery below; midribs yellow; stipules minute, soon falling. Catkins 1-2 inches long, on short leafy branchlets, loosely flowered. Stamens 5-6 to each scale. Pods smooth, $\frac{1}{4}$ inch long, on long pedicels, the small sessile stigmas having notched lobes. Scales of the catkin woolly, yellow. In the southern Sierra Nevada and extending into Arizona.

S. Mackenziana Hook. Leaves lanceolate or oblanceolate, entire or crenately toothed, narrowed to a long point, dark green above, paler below, 2-3 inches long, $\frac{1}{2}$ inch wide, with yellow midribs and petioles. Catkins densely flowered, erect, 1-1 $\frac{1}{2}$ inches long, on short leafy branchlets with white-downy stems and axes. Stamens 2 to each scale. Pods narrowed to a slender style with short pedicels and notched stigmas. A conspicuous small tree or shrub with glossy leaves and yellow stems and branches. Through Oregon, Washington, California, and eastward. 
S. lævigata Bebb. Black Willow. Trunk straight with dark brown fissured bark. Leaves glossy green on upper surface, paler on lower, lanceolate to oblong, mucronate to pointed, 3-7 inches long, $\frac{3}{4}-1 \frac{1}{2}$ inches wide, entire or serrulate. Catkins on leafy branchlets, laxly but rather densely flowered. Stamens 5-6 to each scale. Pods smooth, brownish, on short pedicels, with short style or none, and notched stigmas. Scales of the catkin pale and hairy, toothed. Along streams at middle elevations in the Coast Mountains and Sierra Nevada.

S. amygdaloides Anders. Peach Willow, Almond Wrllow. Leaves lanceolate, tapering to a long point, minutely glandular-toothed, bright green above, paler beneath with yellow midrib, $2 \frac{1}{2}-4$ inches long, $\frac{3}{4}-1 \frac{3}{4}$ inches wide. Stipules kidney-shaped, glandular-toothed. Catkins 2-3 inches long. Stamens 5-9 to each scale. Pods smooth, on long pedicels with short style and 2-lobed stigma. British Columbia to Oregon and Washington along streams in the interior, but rare.

S. fluviatilis Nutt. SAND-BAR WILLOW. Small tree or shrub from smooth to white-woolly. Leaves linearlanceolate, tapering to a long point, 2-6 inches long, $\frac{1}{8}-\frac{1}{3}$ inch wide, glandular-toothed, paler on the lower than on the upper surface and with yellow midribs. Catkins on leafy branchlets appearing after the leaves, the staminate 1 inch long, with 2 stamens to each scale, the pistillate 2-3 inches long. Pods loosely spreading on short pedicels, and with broad, sessile, lobed stigmas. Widely distributed in various forms throughout all the region adjacent to the Pacific Coast, growing along river banks and sand-bars.

S. sessilifolia Nutt. PALE Wrlow. Leaves sessile, lanceolate or linear-lanceolate, tapering to a long point, 
entire or sparingly toothed, gray-green from the white hairs that clothe both sides, but becoming smoother with age; $1 \frac{1}{2}-5$ inches long. Catkins at the ends of short leafy branchlets, the staminate about an inch long, the pistillate 3 inches; stamens 2 to each scale. Pods on short pedicels or sessile, woolly. Style short; stigmas with linear lobes. The typical form is common in Oregon and northern California. In the Coast Mountains and valleys along streams is found the variety Hindsiana with narrower leaves, entire and paler gray. It forms conspicuous clumps wherever it is found.

S. lasiandra Benth. Black Willow. Trunk dark brown, fissured. Leaves lanceolate, tapering, smooth and green above, paler below, closely and sharply serrate; petioles glandular at upper end. Stipules often large, half-moon shaped, edged with glandular teeth. Pods lanceolate, on short pedicels with short styles and 2-cleft stigmas. Stamens 5 or more to each scale; the scales thin, yellowish, hairy or smooth. From California to British Columbia.

S. lasiolepis Benth. White Willow. Shrub or tree with smooth grayish bark. Leaves oblanceolate or oblong-lanceolate, 4-6 inches long, $\frac{1}{2}-1$ inch wide, obtuse, more or less pubescent, often densely woolly on lower surface, thick and leathery, marginal teeth inconspicuous. Catkins densely flowered, $1 \frac{1}{2}-3$ inches long;

S. taxifolia H.B.K. YEW-LEAVEd Willow. Leaves linear-lanceolate, acute and mucronate at apex, entire or with a few minute teeth near the top, almost smooth, pale green, $1 / 3-1 / 3$ inches long, very narrow. Catkins densely flowered, 1/4-1/2 inch long; stamens 2 to each scale. Pods woolly, on short pedicels. Stigmas sessile and deeply notched. Along mountain streams of southern Arizona.

S. Bonplandiana H.B.K. EvERgREen WILLOW. Leaves evergreen, linear-lanceolate, tapering to a slender point, minutely glandular-toothed or entire and revolute, yellow-green above, silvery white below, 4-6 inches long, $1 / 2-3 / 4$ inch wide, the midribs yellow. Catkins 1-11/2 inches long; stamens 3 to each scale. Pod slender, smooth, with 2 thick club-shaped sessile stigmas, the base surrounded by a cupshaped disk. Mountains of Arizona. The only evergreen North American willow. 
stamens 2 to each scale. Pods smooth, acute, dark green, on short pedicels, the styles medium, tipped by short erect stigmas. Scales dark, densely clothed with crisp white hairs. Extending through California, inhabiting stream banks and dry arroyos; found even in the sand-hills of the coast, extending north to Oregon.

S. Nuttallii brachystachys Sargent. Small tree or shrub with brown-gray fissured bark. Leaves obovate or oblanceolate, acute, acuminate, or obtuse, 2-3 inches long, 1-2 inches wide, entire or serrate, dull green above, clothed with silky tangled hairs below, often felt-like, sometimes tawny. Catkins sessile, oblong, recurving, short; stamens 2 to each scale, with long filaments. Pods densely woolly, on short pedicels. Stigmas sessile, entire or deeply parted, with reflexed linear lobes. Scales blackish, with long, silky, white hairs. Common along the coast from Santa Barbara to Alaska.

S. Sitchensis Sans. Velvet Willow. Leaves oblong, ovate or oblanceolate, acute or obtuse, 1-5 inches long, $\frac{1}{2}-2$ inches wide, dark green and veiny on the upper side, clothed with dense white wool beneath but becoming smoother with age. Catkins erect, sessile or on short stems with bract-like leaves below, appearing before the leaves, 2-4 inches long. Stamens 1-2 to each scale. Ovary with short pedicel narrowed to a short style with entire or notched stigmas. Scales of the catkin yellow, clothed with long white hairs. Commonly a shrub. Found from Santa Barbara to Alaska.

Salix Hookeriana Barratt. Leaves oblong or oblong-oborute, shortly pointed. coarsely and bluntly serrate, sometimes eutire, upper purt yellow-green, lower clothed with silvery white down, 2-6 inches long, 1-11/2 inches wide. ('utkins on very short stems with a few small leaves at buse, 11/2 inches long. Stumens 2 to each hairy scale. Pods narrowed to a long style with brond stigmus; the pedicels short. Along the coast from Vaneonver Island to sonthern () regon. 


\section{PoPUlus. ${ }^{1}$ Cottonwood, Poplar, Aspen.}

\section{Plate XXII.}

Leaves broad, glandular-crenate. Buds scaly, generally resinous. Catkins appearing before the leaves, pendulous, axillary, the bracts toothed or fringed. Stamens inserted on a disk with distinct filaments and purple anthers that stain the ground where they fall. Pods ovate or globular from a cup-shaped disk, loose. Styles 2-4, lobed or divided, often united at base.

P. tremuloides Michx. Aspen. Slender tree, 20-50 feet high, with straight slender trunk, grayish white smooth bark covered with a bloom in the spring. Leaves broadly ovate to orbicular, 1-3 inches across, tapering near the top, cordate or wedge-shaped at base, crenulate. Petioles slender, flattened contrary to the blade so that the leaves move in the slightest breeze. Stamens 6-10 to each disk, with short filaments. Pods smooth, small, on slender pedicels, splitting into 2 parts when ripe. In the Sierra Nevada at the elevation of the pines, 600010,000 feet.

P. trichocarpa Torr. \& Gray. Balsam Cottonwood. Tree 30-50 feet high with cracked bark. Leaves broadly ovate to oblong-lanceolate, pointed, cordate or rounded at base, the lower surface much paler green than the upper. Petioles not flattened, margin crenate. Staminate

1 Populus balsamifera $L$. BALsam CotTonwood, Leaves ovate-lanceolate, acute or more pointed, dark green on upper side, gray or tinged with brown on the lower. Leaf buds and young leaves very viscid, 3-5 inches long, 11/2-3 inches wide. Catkins loosely fruited. Pods ovate-acute. Becomes a tall tree in eastern Oregon and Nevada.

P. angustifolia James. NARRow-LEAVED CoTTONWOOD. Leaves lanceolate or ovate-lanceolate with tapering top, coarsely serrate with incurved teeth, almost smooth, slightly paler on the lower side. Catkins densely fruited. Pods short, ovate, with 2 dilated lobed stigmas. Eastern Oregon, Nevada, and Arizona.

P. Mexicana Wesmael. Leaves ovate, long-pointed or broader and less pointed, crenate-serrate. In southern Arizona along mountain streams. 
catkins densely flowered, with filaments as long as the anthers. Pods almost sessile, round, splitting into 3 parts when ripe. Throughout California along streams, but not near the coast.

P. Fremontii Watson. Fremont's CotTonwood. Large tree with spreading branches, bark gray, cracked. Leaves broadly triangular, $2-4$ inches broad, $1 \frac{1}{2}-3$ inches long, abruptly pointed at apex, with a broad inward curve at base, green on both sides, smooth, with rounded teeth on the margin except near the apex and base. Petioles not flattened. Staminate catkins densely flowered with many stamens to each disk. Anthers dark red. Pods ovate, on short stout pedicels, splitting generally into 3 parts when ripe. Grows along water courses in the valleys of the Coast Mountains, Sierra Nevada, and great interior valley.

\section{MYRICACEA. WAX-MYRTLE FAMILY.}

Trees or shrubs with alternate, simple, fragrant leaves. Flowers and fruits in short, sessile, erect catkins; the pistillate and staminate flowers rarely in the same catkin, each destitute of calyx or corolla, solitary and sessile in the axil of a scaly bract, the staminate of $6-16$ united filaments and reddish anthers, the pistillate a 1-celled, 1-ovuled ovary and 2 thread-like stigmas. Fruit in short spikes, each berry like a small dark purple pea, the granular surface unevenly coated with grayish white wax.

MYRICA. WAX-MYRTLE, BAYBeRRY.

Plate Xíili.

M. Californica Cham. Small tree or shrub, :3-30 feet high. Leaves evergreen, oblanceolate, 2-4 inches long, 
$\frac{1}{2}$ inch or less wide, acute at apex, narrowed- to a short petiole, serrate especially towards the top, smooth, dark green, glossy. Staminate and pistillate flowers on the same plant, the catkins solitary or more often densely clustered in the leaf axils. Common along the coast from Los Angeles to Washington, generally growing in the shade along water courses.

There is one other species in California, M. Hartwegi Watson. This is only a shrub. Leaves deciduous, aromatic. Pistillate and staminate flowers on separate plants. Fruit winged by sharply tipped bractlets. Stamens 3-4 to each flower. In the Sierra Nevada near Lake Tahoe, Yosemite, Wawona, etc.

JUGLANDACE

JUGLANS. WALNUT.

Plate XXIV.

J. Californica ${ }^{1}$ Watson. California Walnut. Leaves alternate, odd-pinnate with numerous serrate leaflets, 5-8 pairs, each leaflet about 2 inches long. Staminate and pistillate flowers on the same tree but separate, the former becoming a globular, solitary nut about an inch in diameter, covered with a dry; dark brown husk when ripe; staminate flowers in catkins 4-8 inches long, loosely flowered, with 30-40 stamens to each flower. Tree 4050 feet high with spreading branches. Found near the base of Mount Diablo and Mount St. Helena, also along the lower Sacramento and extending south to Santa Barbara. A tree of somewhat limited distribution but of great beauty.

1 Juglans rupcstris Engelm. Is similar but with shorter catkins and somewhat smaller nuts. It grows in southern Arizona and the country adjacent, generally along streams. 


\section{BETULACE}

Trees or shrubs with deciduous, alternate, toothed leaves. Pistillate and staminate catkins on the same tree; when young covered with resin but not protected by bud scales; staminate catkins pendent, elongated, each flower consisting of 2-4 stamens in a 4-lobed or scale-like calyx under the bracts of the catkin; pistillate flowers in short erect cones, each flower having a 2-celled ovary and 2 stigmas but neither calyx nor corolla.

\section{BETULA. BIRCH.}

Stamens 2 with 2-forked filaments and separate anther cells. The staminate catkin with shield-shaped bracts; pistillate catkins with 3-lobed bracts and winged seeds, the bracts and seeds falling from the axis when the seeds are ripe. Trees or shrubs with smooth bark in layers. Flowers appearing with or before the leaves.

B. fontinalis Sargent. Black Birch. Small tree or shrub 10-20 feet high, with brown bark on trunk. Branchlets dotted with resinous glands. Leares thin, broadly ovate, 1-1 $\frac{1}{2}$ inches long, margin with glandtipped serratures, sometimes slightly lobed, resinous on the upper surface, sometimes downy on the lower. P'etioles slender, almost half an inch long. In northern California along mountain streams and in the sierra Nevada chiefly on the eastern side.

\section{ALNUS. ${ }^{1}$ A I.DER.}

Plate XXV.

Stamens to each flower 4, opposite the lobes of the

1 Alnus Sitchensis Sargent. Simall tree or shrub. leaves brombly ovate, cremutely lobed, the short lobes sharply glandular-serrate. Stuminnte antkins 1 is fuches long. Cones about $1 / 2$ inch long, on slender stems, often in componmel lonfy elusters. Seeds winged. From Alaska to oregon. 
small calyx, with very short filaments and anther cells close together. Scales of the staminate catkin shieldshaped, on short stems; pistillate catkins erect, becoming dark brown and woody, persisting on the tree after the seeds have fallen, resembling small cones. Trees or shrubs with catkins appearing before or with the leaves.

A. Oregona Nutt. Red Alder. Bark pale gray or white mottled with darker gray. Leaves ovate or elliptical, rusty pubescent on the lower surface, doubly serrate with revolute margins to the teeth. Cones oblong, almost an inch long. Seeds winged. Winter buds glutinous, almost $\frac{1}{2}$ inch long. In cañons near the coast throughout the state and extending to Alaska. (A. rubra Bong.)

A. rhombifolia Nutt. Bark light brown, smooth. Leaves ovate or oval, paler beneath, irregularly glandular-toothed. Cones oblong, almost an inch long. Seeds margined but not winged. The fruit ripens early in the year, as the next season's flowers are blooming. Widely distributed throughout California.

A. tenuifolia Nutt. A small tree, or often forming thickets. Bark red-brown. Leaves ovate, rounded or heart-shaped at base, doubly serrate with acute teeth, veins prominent. In the Sierra Nevada and northward, especially on the eastern slope of the mountains.

\section{CUPULIFERA. OAK FAMILY.}

Trees or shrubs with lobed, dentate, serrate or entire leaves. Staminate and pistillate flowers on the same plant, but separate; the former in fringe-like catkins or in spikes; the latter forming in fruit either a nut in a cup-like involucre, called an acorn, or one or more nuts enclosed in a bristly covering called a bur. 


\section{QUERCUS. OAK.}

Staminate flowers in drooping, fringe-like catkins (erect in $Q$. densiflora, the tan bark oak), each flower with a 6-lobed perianth; pistillate flowers usually single, consisting of a 3-celled ovary which becomes an acorn with only one ovule maturing to form the nut. Stigmas 3.

Black OAKs.

Bark dark, almost black; leaves dark green and glossy.

Deciduous species.

Q. Californica Cooper. Black OAK, Kellogi's OAK, Yosemite Oak. Plate xxv, fig. 1. Leaves with sharppointed pinnate lobes, the spaces between the lobes broad and shallow, the lobes coarsely and sharply toothed, 4-9 inches long, 2-4 inches broad. Acorns ripening the second season, on short stalks, often solitary; nut oral in outline, obtuse, 1 inch long, often downy; cup large and deep, about an inch broad, clothed with thick obtuse scales. When the young leaves begin to unfold in the spring they look like flowers, being rose-color and downy; some young trees have all the leaves densely white-downy. One of the commonest oaks, becoming a noble tree $70-80$ feet high in the Coast Mountains not far from the sea, from the northern to the southern part. It is the chici oak in the yellow pine belt in the Sierra Nevala; Yosemite, Lake Tahoe, Kings and Kern cañons, Mount shasta.

Q. Morehus Kellogg. P'Late xxvi, Fic. 2. Leaves oblong, 3-4 inches long, 1-2 inches broad, coarsely toothed, the teeth sharply pointed and the spaces between broad and shallow. Acorns ripen the second seanson; solitary on short stems; nut ohlong, obtuse; the cup much shorter with smooth ovate scales. Shrub or small 
tree in the Coast Mountains and the Sierra Nevada; always rare and never forming forests; more often shrubby than arborescent. It is considered by some to be a hybrid between the preceding and the following species. It does not lose its leaves until the new leaves are almost ready to appear.

\section{Leaves persistent and evergreen.}

Q. Wislizeni A. DC. Live OAK. Plate xxvi, fig. 3. Leaves stiff, bright green, somewhat holly-like, smooth and glossy, spiny-toothed or sometimes entire, 1-5 inches long. Fruit matures the second season; the acorns sessile or on very short stems; nut variable in size and shape, sometimes almost completely enclosed in the rough-scaly, deep urn-shaped cup, generally acute. In the foothills of the Sierra Nevada this is the common live oak, forming a rounded symmetrical tree of some size, often with low spreading branches. In the Coast Mountains back from the coast it also becomes a goodsized tree, but more often it is shrubby on the dry hills, forming most of the oak chaparral. It extends from Mount Shasta to San Diego County and to the mountains of Los Angeles, Riverside, and San Bernardino counties.

Q. agrifolia Née. Live OAk. Plate xxvi, fig. 4. Leaves oval or oblong, the edges folding back so as to be concave on the lower side, spiny-toothed; pubescence of star-shaped scales conspicuous on young leaves but found only along the veins of the lower surface in old leaves. Acorns ripen in one season; nuts slender, pointed; cup small with smooth glossy scales. The live oak of the coast hills, forming a great part of the verdure of the green-topped hillocks with their summer background of tawny brown. Trees growing in favorable situations become very large, with great spreading branches which 
are often near the ground or prostrate. Found only in the Coast Mountains and as far inland as the influence of the coast fogs penetrates, from north of San Francisco to Southern California.

\section{White OAKs.}

Bark usually light gray.

\section{Deciduous species.}

Q. lobata Née. Weeping OAK, Valley OAK, White OAK, Roble. Plate xxvis, fig. 1. Leaves deeply lobed with obtuse divisions, 3-5 inches long, 2-4 inches broad; upper surface dark green and stellate pubescent, lower surface paler and more densely pubescent. Acorns long and pointed, 1-3 inches; ripening the second season; the cup deep with a rough warty surface. A beautiful large tree often with pendent sterile branches from which the name, 'Weeping Oak,' is derived. Grows most luxuriantly in open fertile valleys, somewhat isolated, giving the country a park-like aspect. Is found in both the Coast Mountains and the Sierra Nevada from the upper. Sacramento to Los Angeles County, but is not common south of Tehachapi. It does not extend above the foothill region of the Sierra Nevada.

Q. Garryana Douglas. Mountain White OAk. Plate xxviI, FIG. 2. Leaves thick, strongly reined, coarsely lobed with obtuse or acute lobes which are entire or again lobed, 4-6 inches long, 2-5 inches wide; upper surface glossy, lower paler, turning brown or red in the fall. Fruit ripens the second season. Acorns sessile or on short stems; nut oval, obtuse; cups small and shallow. It is similar to the preceding in some ways but is readily distinguished by the large tomentose winter buds. Common in Oregon and Washington and extends through 
the Coast Mountains to Santa Cruz County. It is the white oak of northern California and is generally found growing among the hills.

Q. Douglasii Hook. \& Arn. Blue OAK, Hill OAK, White OAK. Plate xxvis, fig. 3. Leaves an inch or two long, oblong, with shallow, obtuse lobes, veiny, bluegreen. Cup generally shallow, with flat scales; nut oblong, often swollen in the middle. Large or mediumsized tree, with spreading habit. Conspicuous on hillsides from the white trunks and blue-green leaves. Found in valleys and cañons of the Coast Mountains and the foothills of the Sierra Nevada from Mendocino County and the upper Sacramento to Tehachapi and a little south of there.

Q. Alvordiana n.sp. Plate xxvir, fig. 4. Small tree or shrub on hills near the desert. Leaves small, brittle and easily falling, dentate. Branches tough, widely spreading. Acorns long and very slender, with small, rather smooth cups. A little known oak in the mountains connecting the Coast Range with the Sierra Nevada at the southern end of the San Joaquin Valley bordering the deserts. It is named in honor of the late William Alvord, a former president of the California Academy of Sciences.

Q. MacDonaldi Greene. Island OAk. Plate xxviI, FIG. 5. Leaves spatulate-oblong, pinnately lobed, with acute lobes tipped with sharp points, $2 \frac{1}{2}$ inches long; lower surface densely clothed with star-shaped hairs; smooth on the upper; base generally unequal and obtuse. Fruit matures in one season; sessile, less than an inch long; the nut ovate-oblong, acute, cup rather deep, tuberculate. Small tree 15-35 feet high, symmetrical and graceful with rounded top and slender branches. Grows near streams on Santa Cruz and Santa Catalina 
islands. It is named in honor of Captain James M. McDonald, who published 'West American Oaks.'

\section{Leaves persistent and evergreen.}

Q. Engelmanni Greene. Live OAK of Southern California. Plate xxviII, fig. 1 . Leaves on very short stems, oblong, 2-3 inches long, entire or with few teeth, obtuse or slightly cordate at base; young leaves serrate, downy, becoming smooth with age, dull green, often notched at apex. Acorns on long stems; nut oblong, marked with longitudinal lines, 1 inch long; cup tuberculate. Becomes a tree 25-40 feet high, with smooth trunk 2-3 feet in diameter. From Kern to San Diego counties.

Q. chrysolepis Liebm. Golden-Leaf OAK, Maul Oak, White Live Oak. Plate xxvin, fig. 2. Leaves elliptical, oblong-lanceolate or ovate-lanceolate, acute, spinytoothed or entire, upper surface bright green, lower in young leaves clothed with golden scales, becoming pale gray-green and smooth in age. Fruit matures in two seasons. Acorns solitary, generally sessile, extremely. variable in respect to both eups and nuts; some cups broad and shallow like saucers, some deep bowl-shaped, scarcely alike on any two trees. Trees in the Sierra Nevada have the cups so densely covered with yellow down that the scales cannot be discerned. A widely distributed species, becoming a tall large tree in cañons along streams; in the Coast Mountains frequently clothing high open summits and becoming a tree with large widely spreading branches and thick short trunk; above the foothill region in the southern Sierra Nevada associated with the nut pine on dry hills; also in the mountains of San Bernardino, Riverside, and san Diego counties. 
Q. tomentella Engelm. Island OAK. Plate xxviII, FIG. 3. Leaves oblong-lanceolate, 3-4 inches long, obtuse at base, obtuse or acute at apex, entire or with rounded teeth, thick, densely tomentose when young, becoming smooth on the upper surface when old. Nut large, ovate; cup broad and rather shallow, tomentose on the inner surface, scales of the outer tipped with appendages. Tree of medium size, symmetrical, with tomentose branchlets. Santa Cruz, Santa Rosa, San Clemente, and Catalina islands.

Q. densiflora Hook. \& Arn. TAn-BARk OAK, Chestnut OAK. Plate xxviII, Fig. 4. Leaves thick, strongly veined, oblong, 2-5 inches long, an inch or more wide, entire, serrate or dentate, with short petiole; upper surface somewhat tomentose, bright green, lower densely tomentose. Catkins erect in flower, densely clustered and very numerous, with a strong and disagreeable odor when in bloom; staminate flowers above the pistillate ones on the same catkins. Acorns numerous, clustered; nuts oblong, inch long; cup densely clothed with weak fringe-like appendages; in bloom in summer, the fruit fully grown at the same time, taking a full year to mature. Noble tree of the Coast Mountains, becoming

ARIZONA OAKS.

Quercus Gambellii Nutt. WhITE OAK. Leaves deciduous, obovate in outline, obtusely lobed, bright green above, pubescent below. Acorns sessile or on short stems, small. Generally shrubby, but becomes a small tree in the mountains of Arizona.

Q. undulata Torr. Leaves deciduous, oblong, entire, wavy or with sharply tipped lobes, blue-green. Acorns sessile or on short stems. Becomes a small tree in the mountains of Arizona, but is generally a shrub.

Q. oblongifolia Engelm. Leaves persistent, blue-green, oblong, obtuse or cordate at base, entire to spiny-toothed. Acorns small, generally solitary on slender stems. A small tree in the foothills of the Arizona mountains.

Q. Arizonica Sargent. Leaves persistent, blue-green, oblong-lanceolate to broadly obovate, cordate at base, or obtuse, spiny-toothed, very veiny on the lower surface. Acorns small, sessile or on short stalks. A small tree in the mountains of Arizona. 
150 feet or more in height; often spreading, with immense trunks and branches. In its method of flowering it is peculiar and forms a link between the chestnuts and the oaks. Its nearest relatives are in Asia. (Pasania densiflora Örst.)

\section{CASTANOPSIS. ChInquapin.}

\section{Plate XXIX.}

C. chrysophylla A. DC. Leaves lanceolate, pointed, 3-6 inches long, $\frac{1}{2}-2$ inches wide, dark green on the upper surface, the lower yellow with a dense pubescence, becoming smoother in age, entire. Flowers in erect axillary or terminal spikes, generally clustered; staminate flowers sessile on the upper part of the spikes, with twice as many stamens as divisions of the perianth, these 5-6; pistillate flowers below in a scaly involucre. Ovary 3 -celled with 2 ovules in each cell (maturing 1-3 nuts in a roundish involucre densely covered with brown intricately branching prickles). Blooms chiefly in summer, fruiting about the same time. Is generally shrubby, but becomes a large and beautiful tree in Mendocino County. Throughout California in the Coast Mountains. The shrub of the Sierra Nevada, C. sempervirens Dudley, has leaves obovate-oblong, obtuse at apex. It never becomes a tree.

Q. reticulata $H$. \& P. Leaves persistent, blue-green, broadly obovate, cordate at base, the apex rounded, coarsely veiny, spiny-toothed with slublow teeth. Acorns small, sessile, in spikes 2-5 inches long; the stems persistent. Mountains of southern Arizona.

Q. Tuomeyi Sargent. Leaves persistent, blue-green, small, ovute to oblong, entire to spiny-toothed. Acorns small, sessile, solitary or in pairs. Mountuins of Arizoma.

Q. Emoryi Torr. Bı.Аск ОАк. Bark almost black. Leaves persistent, dark green, oblong-lanceolate, entire or wavy and serrate, tongh. Acorms sessile or on short stalks. The nuts are used as food by the Mexicans and are culled 'biotis'. Common in southern Arizona.

Q. hypoleuca Engelm. Leaves persistent, the upper sicle green, the lower white from the dense conting of white wool, lanceolate or elliptienl, cutire or spinytoothed. Acorus small, solitary, sessile or on short stout stems. Yomutafus of Arizona. 


\section{CELTIDACEe. Hackberry Family.}

Trees or shrubs with stipules that soon fall. Pistils and stamens generally in separate flowers on the same plant, sometimes in the same flowers; petals wanting; stamens with filaments folded in the bud but straightening as the flower opens, (in the perfect flowers remaining folded); anthers opening toward the 2 broad styles of the simple pistil. Fruit a drupe.

\section{Celtis. Hackberry, Sugar Berry.}

\section{Plate XXX.}

C. reticulata Torr. Somewhat pubescent with short spreading hairs. Leaves alternate, deciduous, ovate with pointed apex, obliquely cordate at base, veiny and rough, often covered with wart-like galls, dark green on the upper surface, paler below, sharply serrate or almost entire, 2-4 inches long, 1-2 inches wide. Flowers small, greenish yellow, in small scattered bunches of 2 or 3 on slender hairy stems; calyx divisions extending to the base, of 5 ovate-lanceolate papery lobes with a tuft of hairs at the tips. Fruit ovate, orange-red when ripe, as large as a green pea, with thin flesh and smooth light brown nut. Shrub or small tree found in Southern California along the border of the desert; not common. In bloom in the early spring; in fruit in the fall.

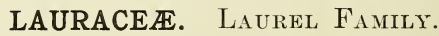

Aromatic trees or shrubs. Flowers with perianth of 6 petal-like divisions; stamens 9 , in 3 rows, the inner with 3 glands at base alternating with tongue-shaped staminodia; anthers opening by small valves hinged at the top like a trapdoor; ovary free, 1-celled, forming a fruit like a plum or olive. 
UMbellularia. California Laurel or Bay, Spice Wood, Pepper Wood.

Plate XXXi.

U. Californica Nutt. Leaves evergreen, glossy, lanceolate-oblong, on short petioles. Flowers yellow, small, in umbels which before opening are enclosed in involucres that are soon deciduous. Fruit purple or greenish yellow when ripe, about an inch long, solitary or clustered on a short stout stem. Grows not far from water, forming large handsome trees, or becoming shrubby on hillsides. In bloom soon after the beginning of the rainy season. Found chiefly along the coast from Oregon to San Diego; also in the Sierra Nevada along the high western ridge and south to the higher parts of the San Bernardino Mountains.

\section{PLATANACEA. Sycamore Family.}

Leaves alternate, large, palmately lobed; stipules large, sheathing. Flowers in round balls strung at intervals on an axis, the pistillate and staminate on different axes; calyx and corolla wanting; stamens with short filaments and large anthers; pistils simple, each with 1 ovary, ovule, and style.

\section{Platanus. Sycamore, Plane Tree.}

\section{Plate XXXiI.}

P. racemosa Nutt. Srcamore. Leaves 5-6 inches broad, 5-lobed with acute, entire divisions, downy, with stellate pubescence. A large tree with spreading branches. Trunk mottled gray and white. Along streams in the Coast Mountains and in the San Joayuin Valley; from Alameda ('ounty to San I)iego and sim Bernardino counties. 


\section{ROSACEA. ROSE FAMILY.}

Herbs, shrubs, or trees. Leaves alternate, with stipules, though these are often small and deciduous. Stamens numerous on the persistent calyx; petals separate, sometimes wanting, soon falling.

Fruit with the outer coat fleshy; the seed within the stony inner coat (drupe or stone fruit).

Stone globular.

Cerasus, Cherry.

Stone flattened. Prunus, Plum.

Fruit with the ovary contained in the calyx, which becomes fleshythe whole being called a pome.

Ovary with 2-5 cells, becoming papery in fruit (the apple core).

Malus, Apple.

Ovary 2-5-celled, with seeds like stones.

Cratægus, Thorn.

Ovary 2 -celled, fruit a berry.

Heteromeles, Toyon, Christmas Berry.

Fruit of 1 or 2 carpels containing 1 or 4 seeds, included in the calyx tube, which does not become fleshy.

Carpels 1-seeded, with feathery tails.

Carpels 2. each 2-seeded.

Cercocarpus, Mountain Maho.

Lyonothamnus.

\section{CERASUS. Cherry.}

Trees or shrubs without spines. Flowers white, in racemes or corymbs. Fruit with stone almost globular (not flattened).

C. ilicifolia Walp. Islay, Holly-leaved Cherry. Plate xxxin. Leaves glossy, evergreen, spinytoothed. Flowers in leafless racemes, $\frac{1}{2}-3$ inches long. Fruit large, half inch or more in diameter, red or black-purple, the stone almost filling it. More often a shrub than a tree. Found in cañons or on dry hills from near San Francisco to San Diego County.

C. Lyoni n. nom. A fine and beautiful tree when in bloom. With large ovate leaves, pointed at tip, entire or rarely with a few spiny teeth. Racemes longer and 
more numerous than in the preceding; fruit larger, with thicker pulp. On the islands off the coast of Santa Barbara; particularly notable on Santa Catalina Island. (Prunus integrifolia Sargent.)

C. demissa Walp. Choke-cherry. Generally shrubby. Leaves oblong to ovate, broadest above the middle, shortly pointed, 2-4 inches long, serrate with straight teeth, pubescent on lower surface. Flowers in manyflowered pendent racemes. Fruit globose, black when ripe, sweet but astringent; few left on the racemes owing to the birds. Throughout the state not far from water; nowhere common; extends into Oregon and Washington.

C. emarginata Walp. Bitter Cherry. Small tree with slender reddish twigs. Leaves obovate or oblanceolate, $1 \frac{1}{2}-3$ inches long, obtuse or acute at apex, serrate with fine teeth, somewhat pubescent on the lower surface, with 2 glands near the summit of the leaf stalk. Flowers in corymbs which are shorter than the leaves. Fruit oval, dark red, astringent and bitter, $\frac{1}{3}$ inch in diameter. In the mountains of middle and northern California, but not common.

\section{PRUNUS. Wild Plum.}

\section{Plate XXXiv.}

P. subcordata Benth. Trees or shrubs, generally. thorny. Flowers white, in sessile umbels appearing with or before the leaves. Leaves ovate, corlate at base. the apex obtuse or acute, sharply and finely serrate, about an inch long, finely pubescent. Corolla a hali inch in diameter. Fruit a red plum, $\frac{3}{4}$ inch long, not palatable. A shrub in the Coast Mountains and at upper elevations in the Sierra Nevada; a tree in northern ('alifornia and Oregon. 
P. subcordata var. Kelloggii Lemmon. Sierra Plum. Fruit yellow, juicy and sweet. Leaves wedge-shaped at base, almost smooth. In Shasta and Sierra counties and northward.

\section{MALUS. APPLE.}

\section{Plate XXXV.}

M. rivularis Dec. Crab ApPLE. Shrubs or small trees with the young parts woolly. Leaves deciduous, alternate, simple or lobed, ovate-lanceolate, acute or pointed, 1-3 inches long, glandular-serrate, green on upper surface, white-downy on lower. Flowers white, $\frac{3}{4}$ inch across, in simple cymes that sometimes become racemose, leafy at base; calyx divisions 5, falling with the stamens; petals orbicular; stamens 20 , styles $2-4$, smooth. Fruit red or yellow, obovate-oblong, half an inch or more long, the outside being the fleshy calyx tube, the papery core the seed vessel, with generally 3 cells having 1-2 seeds in each. From Sonoma County northward. Not common in California. Grows in shady places, often along streams; extends north to Oregon and Washington. (Pyrus rivularis Dougl.)

CRATagus. Thorn Apple, Hawthorn.

Shrubs or small trees with thorny branches. Leaves deciduous, simple, toothed or lobed. Flowers white, in corymbs. Fruit a round berry containing $2-5$ bony or stony seeds either separable or united into 1 ; the calyx lobes persistent on top, the pulp being the fleshy calyx tube.

Amelanchier alnifolia Nutt. SERvice BERry. A common shrub in California; sometimes becomes a small tree in Oregon and Washington. Leaves oblong to orbicular, becoming smooth, toothed on the upper margin. Flowers white in ereet racemes; calyx cup-shaped, with linear lobes; petals narrowly oblong, 1/4-1 inch long. Fruit a purple berry when ripe, tipped with the persistent calyx lobes, and generally covered with a glaucous bloom, $1 / 4^{-1 / 2}$ inch in diameter. 
C. rivularis Nutt. Leaves ovate or oblong, obtuse or acute at apex, tapering at base to a short slender stem, irregularly serrate or rarely lobed, 1-2 inches long. Flowers almost half an inch in diameter, in small corymbs; calyx lobes short and obtuse; fruit almost black. Not common; from Sierra and Plumas counties northward to Oregon and Washington.

C. Douglasii Nutt. Leaves broadly ovate, somewhat lobed or slashed, finely serrate, somewhat woolly on both sides, $1 \frac{1}{2}-3$ inches long, obtuse at base or tapering to a short stem. Spines on stem an inch long. Flowers in corymbs, generally numerous, $\frac{1}{2}-\frac{2}{3}$ inch in diameter; lobes of calyx lanceolate, pubescent; petals orbicular. Fruit dark purple, $\frac{1}{2}$ inch in diameter, sweet and edible. Found in northern California in the mountains, but not common; extends to Oregon and Washington.

Heteromeles. Toyon, Christmas Berry.

Plate XXXVi.

H. arbutifolia Roem. Shrub or small tree, the younger parts white-downy but becoming smooth with age. Leaves evergreen, glossy, simple, oblong-lanceolate, 2-4 inches long, acute at each end, sharply toothed, the edges often folding backwards. Flowers white, $\frac{1}{4}$ inch in diameter, numerous, in much branched panicles; odor sickening; petals 5 spreading; stamens 10 in pairs opposite the calyx teeth; fruit an obovate red berry $\frac{1}{3}$ inch in diameter, slightly longer, seeds 1 or 2 in each of the 2 cells. In bloom in summer; fruiting from October to February, the berries persisting long after they are ripe and making one of the most ornamental trees or shrubs. The berries are extensively used as Christmas decorations and are therefore known as California holly. Found in 
the Coast Mountains, in the foothills of the Sierra Nevada, and in the San Bernardino Mountains. The berries are very rarely yellow and the trees attain the largest size on the islands off the coast of Santa Barbara.

\section{CERCOCARPUS. Mountain Mahogany.}

\section{Plate XXXVII.}

Shrubs or small trees with very hard wood. Leaves evergreen, alternate, simple, serrate or entire. Flowers small; petals wanting; calyx tubular with 5-lobed, saucershaped border upon which the numerous stamens are inserted in 3 rows, the border falling off and leaving the tube that contains the seed vessel, tipped by the feathery style when ripe.

C. ledifolius Nutt. Leaves narrowly lanceolate with the margins turned under, thick and leathery, bright green and smooth on the upper surface, downy on the lower, $\frac{1}{2}-1 \frac{1}{2}$ inches long, midrib prominent, stem short. Flowers sessile, downy, the tail of the seed 2-3 inches long. Found chiefly on the eastern slope of the Sierra Nevada as a small tree or shrub; also found in Kings and Kern River cañons; in the San Bernardino and San Jacinto mountains on dry dills; also in Nevada and Arizona.

C. betulæfolius Hook. Leaves broadly obovate or narrower in dry situations, with wedge-shaped base, coarsely serrate above the middle, distinctly feather-veined, smooth on the upper surface, pubescent on the lower, $\frac{1}{2}-2 \frac{1}{2}$ inches long. Seed with tail 2-3 inches long. Shrub or small tree with thin flaky bark. Found in the Coast Mountains and foothills of the Sierra Nevada throughout California. The leaves persist through the winter and fall as the new ones appear. 
C. Traskiæ Eastwood. Leaves oval to almost orbicular, 1-2 inches long, 1-1 $\frac{1}{2}$ inches wide, at first clothed with white silky down, later becoming bright green and smooth on the upper surface but densely white-downy on the lower; veins prominent; margins serrate, folding inward in age; almost sessile or with short stems. Flowers in umbels in the leaf axils, densely covered with white down; anthers downy. Seed with tail $1 \frac{1}{2}-2$ inches long. A rare tree found in almost inaccessible cañons on Santa Catalina Island. The most beautiful of all the mountain mahoganies.

\section{LYONOTHAMNUS.}

Plate XXXVIII.

Lyonothamnus floribundus Gray. Trees or shrubs with scaly bark coming off in long strips. Leaves evergreen, opposite, lanceolate, pointed, rounded or wedge-shaped at base, entire, crenate or serrate or variously lobed, closely feather-veined, dark green on the upper surface, paler and pubescent on the lower. Flowers white, small, on slender stems in compound cymes terminating the branchlets; calyx 5-lobed, persistent; petals 5, orbicular, sessile; stamens 15, 2 opposite each petal, 1 opposite each sepal; pistils 2, at bottom of calyx tube. Fruit of 2 woody, glandular, 4-seeded, 1-celled parts, splitting on both sides. A common and conspicuous tree and shrub on Santa Catalina Island. The tree which has been named L. asplenifolius Greene or var. asplenifolius is

Vauquelinia Californica Sargent. Small tree or slurub with stiff (")ntorted brunches. Leaves alternate, narrowly lanceolate, densely elothed with white wool ou the lower surface, light green on the upper, the margin with glandular teoth. Flowers in widely branched panicles terminating the branchlets, stems white-Woully: ('nly: with 5 ovate lobes; petals white, persisting and turuing redulish, reflexed; stumens many; pods ovoid, woody, densely white-woblly, 5-celled tud splitting into is pris. each containing 2 winged seeds. Found in southern Arizomn; becomes n troe in Santa Catalina Mountaius. 
considered by some to be merely a form of the species. It has leaves as shown in figure 2. Found on San Clemente and Santa Cruz islands.

\section{PAPILIONACEA. PeA FAMILy.}

Calyx of 5 sepals, more or less united, often somewhat irregular; corolla of 5 petals, shaped like a pea blossom, the spreading free petal called the banner, the 2 side petals called the wings, the 2 lowest united to form what is called the keel on account of the resemblance to the keel of a boat; stamens 10, either united or all free; pod 1-celled, containing 1-several seeds.

Stamens with filaments united to form a tube; pod 1-seeded, not opening when ripe.

Dalea.

Stamens with 9 filaments united, 1 free; pod splitting when ripe into 2 parts, 1-2 seeded.

Olneya, Iron-wood.

\section{DALEA.}

Plate XXXIX.

D. spinosa Gray. Either a small tree with short trunk or oftener a much-branched shrub, the branchlets terminating in slender spines; clothed throughout with fine white down giving the whole plant a pale gray color. Leaves few, simple, oblong or wedge-shaped, sometimes linear, obtuse, almost sessile, about an inch long, glandular; margins of young leaves toothed, older ones wavy or entire. Most of the time the plant is without leaves as they fall very early. Flowers in short racemes; the stem spine-tipped; pedicels very short; bracts minute; calyx bell-shaped, 10-ribbed, with conspicuous glands between the ribs, the broad teeth reflexed; petals violet, the standard heart-shaped, reflexed, with 2 glands at base, wings and keel joined to the tube of united stamens; - pod flattened, twice as long as calyx, glandular, tipped 
with the persistent style, 1-seeded, not opening. The desert of the Colorado River in San Bernardino and San Diego counties, Palm Springs and other places in dry washes; Arizona.

olneya. Iron-wood, Arbol de Hierro.

Plate XL, Fig. i.

0. Tesota Gray. Small tree, 15-20 feet high, with redbrown flaky bark. Stems spiny with short stout spines in pairs at the bases of the leaf-stalks. Whole plant gray-green with minute appressed hairs. Leaves pinnately compound; leaflets 5-7 pairs, thick, entire, obtuse or notched at top, oblong or wedge-shaped, $\frac{1}{3}-\frac{2}{3}$ inch long. Flowers purplish, loosely arranged on rather long stems in short racemes, which are very numerous; bracts minute and papery, falling before the flower opens; calyx bell-shaped, 5-lobed, the upper 2 united almost to the top; petals all free with claws, the standard broadly orbicular, notched at top, about the same length as the others; stamens with 9 filaments united, 1 free; pod compressed between the large seeds, 1-3 inches long, opening like a pea-pod, 1-5-seeded, rough hairy on the outside and glandular with tack-shaped glands. Leaves and flowers in June; fruit in August. In dry washes of the desert of the Colorado River, Indio, Mesquite Cañon, and elsewhere; Arizona.

CAESALPINEA. SExy F.M MILY.

Flowers more or less irregular with the petals all iree, the upper differing from the others and corresponding to the standard in the preceding family; stamens 10, all distinct.

Leaves simple, round; flowers magenta, in axillary bunches before the appearance of the leaves; standard enclused by the side petals; calyx toothed.

Cercis, Red-bul. 
Leaves compound; flowers yellow; the standard larger than the other petals and with a honey-gland at the base of the claw; calyx divided, with reflexed lobes.

Parkinsonia.

\section{CERCIS. Red-bud, Judas Tree.}

\section{Plate XL, Fig. 2.}

C. occidentalis Torr. More frequently a shrub than a tree. Smooth throughout. Leaves round, cordate, or kidney-shaped, 2 inches across, entire, palmately veined, bright green. Flowers magenta, on thread-like stems in bunches in the leaf axils, appearing before the leaves; calyx bell-shaped with 5 short, broad teeth; petals 5 , the standard enclosed by the side petals; stamens 10, free; pod 2 inches long, $\frac{3}{4}$ inch broad, flat and thin, manyseeded, becoming purplish when ripening, turning brown later. Generally found along streams from northern California to San Diego County; not found near the coast; common at lower elevations in the Sierra Nevada.

\section{PARKINSONIA.}

Plate XLI.

Flowers in axillary racemes on jointed pedicels; calyx 5 -lobed, the lobes reflexed; petals 5, yellow; stamens 10 with filaments all separate, hairy at base, the upper one swollen; pod compressed more or less between the seeds; 2-6 seeded. Trees or shrubs with spiny branches. Leaves compound, with 2-4 parts, each edged with small leaflets.

Leaf axis flat.

P. aculeata.

Leaf axis terete.

P. microphylla, P. Torreyana.

P. aculeata $L$. Retama, Horse-bean. Small tree. Smooth throughout. Branches slender, often drooping. Leaves divided into 2-4 parts near the base; the stalk 
spiny; each part $\frac{1}{2}-1 \frac{1}{2}$ feet long, flat, bearing numerous small, linear-oblong, scattered leaflets; racemes 3-6 inches long; flowers fragrant; an inch across; petals bright yellow, the upper ones marked with red spots; stamens shorter than the petals; pods 2-10 inches long, tapering at each end, longitudinally veined, much constricted between the seeds. Fort Yuma.

P. microphylla Torr. Small tree or shrub, 3-25 feet high, intricately branched, the short branchlets becoming spines. Leaves divided into 2 parts at base, each part with 4-6 pairs of very small, orbicular or oblong, bluish green leaflets on a cylindrical axis. Racemes an inch or less long, $\frac{1}{3}$ inch across. Flowers pale yellow, upper petal white; stamens exserted; anthers orange; pod 1-3-seeded, 2-3 inches long, tapering at both ends; strongly constricted between the seeds. Fort Yuma, Arizona.

P. Torreyana Watson. PAlo Verde. Small tree 20-30 feet high, much branched at top. Light olivegreen smooth bark. Generally leafless on account of the early falling of the leaves, very spiny and often zig-zag between the spines, which are $\frac{1}{4}$ inch long. Leaves an inch long, pale green clothed with white down, divided into 2 parts, each with $2-3$ pairs of oblong, obtuse, pale green leaflets. Flowers yellow, 3-6, in short racemes; calyx 5-lobed with the lobes reflexed in flower and soon falling; petals 5, nearly equal, way-margined, the upper largest, with orbicular blade, the others obovate or spatulate. Pod 3-4 inches long with 2-8 seeds, often slightly constricted between the thick seeds. Flowering in April, fruiting in July. Growing in iny washes of the desert of the colorado River, at Imdio, Toros, and other places. Arizona. (Cercidium Torreyana Sargent.) 


\section{MIMOSE瓜. Acacia Family.}

Flowers regular, numerous, in spikes or heads; calyx and corolla of 4 or 5 divisions; stamens as many or twice as many as the petals, or numerous, inserted on the receptacle. Fruit a pod like a pea-pod, opening in 2 parts when ripe; generally with several seeds.

Stamens 10; flowers greenish.

Stamens numerous; flowers yellow.

Prosopis, Mesquite. Acacia.

\section{PROSOPIS. Mesquite.}

\section{Plate XLII.}

Flowers small, regular; calyx bell-shaped with very short teeth; corolla of 5 petals united below the middle or at length free, woolly on inner side; stamens 10 , free, exserted; anthers tipped by a gland that soon falls; pod elongated, constricted between the seeds or spirally twisted, thick and spongy within, with thick partitions between the numerous seeds. Trees or shrubs. Spiny, with leaves compound, of 2-4 parts, each part with numerous small leaflets. Flowers small, greenish, in cylindrical spikes with stems an inch or less long.

P. juliflora DC. Algaroba, Honey Mesquite. Fig. 1. Leaflets 6-60 pairs, oblong to linear, $\frac{1}{4}-1 \frac{1}{2}$ inches long. Spikes 2-4 inches long; pods 4-6 inches long, on short stems, tapering at top, straight or curved, at first flat, later pulpy within, sweet, edible. In desert regions in Kern, Inyo, San Bernardino, Riverside, Los Angeles, and San Diego counties; also in Nevada and Arizona. The bark exudes a resin like gum arabic.

P. pubescens Benth. Screw-Benn. Fig. 2. Shrub or small tree 15-20 feet high. Old bark shreddy, pale green throughout from the appressed hairs. Each part of com- 
pound leaf with 5-8 pairs of leaflets. Spikes densely flowered, 2-3 inches long. Pod thick, spirally twisted. Desert regions in sandy or gravelly bottom lands; Mohave Desert, Colorado River, San Diego County, Nevada, and Arizona.

\section{ACACIA.}

A. Greggii Gray. Cat's Claw, Uña de Gato. Plate xLIII. Either a small tree 10-20 feet high, much branched, or a straggling shrub. Branches armed with stout recurved spines broad and flat at base, $\frac{1}{4}$ inch long. Leaves pale green, divided into 2-4 parts with 4-5 pairs of leaflets to each part; leaves and spikes clustered at the old leaf axils; leaflets unequal-sided, oblong or obovate. Calyx 5-toothed; petals 5, more or less united. Pod flat, compressed between the seeds, curled or somewhat twisted when ripe; seeds almost orbicular, $\frac{1}{4}$ inch in diameter. Flowering from April to September, the pods persisting. On the western border of the Desert of the Colorado River at an altitude of 2000-3000 feet, at San Gorgonia Pass, San Felipe, Warner's Hot Springs, and other places.

\section{RUTACEA. ${ }^{1}$ LEMON FAMILY.}

Leaves dotted with translucent dots, simple or compound, without stipules, aromatic. Flowers with 4 or 5 petals; stamens as many or twice as many, inserted outside a disk.

1 Canotia holacantha Torr. A smooth, much brauehed, lenfless smull tree or slı rul,. with alteruate branches entiug in stout spines and murked with smull black sonrs. Flowers small, in elusters of $: 3.7$, with short stems jointed below the mildle: enlyx very small, with 5 persistent lobes; petals 5 , oblong, white, reffexent, surpussing the sepals and the short stameis. Pod wooly, tapering to a loug beak forment by the united and persistent styles; filaments and sepals ulso persistent, colls i), wath splitting into parts, seeds with membranous wings. In the Provideme Moumbirs and in Arizona; rot commots. 
PTELEA. Hop 'Tree.

Plate XliV.

P. crenulata Greene. Leaves with 3 sessile leaflets, elliptical to obovate, rounded or acute at apex, crenulate or entire, 1-3 inches long. Flowers small, greenish, in axillary branching clusters, perfect or with stamens and pistils in separate flowers. Fruit 2 -celled, 2 -seeded, orbicular, encircled by a wing, half an inch in diameter. Small tree or shrub in the Coast Mountains and the foothills of the Sierra Nevada, not common; abundant on certain parts of Mount Diablo and in some parts of Lake County.

ACERACE正. Maple Family.

Leaves opposite, palmately lobed or compound. Stipules none. Fruit of 2 parts, each winged. Pistillate and staminate flowers on the same or separate trees.

\section{ACER. Maple.}

Flowers in racemes, corymbs, or fascicles; calyx usually 5 -lobed; petals as many as lobes or none; stamens about 8 , inserted with the petals on a lobed disk. Ovary 2-celled with 2 long diverging styles. Fruit of 2 parts, each containing 1 seed; embryo with large cotyledons.

A. macrophyllum Pursh. Big-Leaved Maple. Plate $\mathrm{XLV}$, FIG. 1. Leaves of rounded outline deeply 5-cleft with the parts again sharply lobed, 6-12 inches broad, becoming smooth. Flowers crowded in pendent racemes, appearing before the leaves, 3-6 inches long; yellowish green. Fruit with smooth, diverging wings; body bristlyhairy, altogether $1-1 \frac{1}{2}$ inches long. A beautiful tree 50-90 feet high, with smooth light gray bark. Leaves conspicuously bright yellow in the fall. Grows along 
water courses in the Coast Mountains and Sierra Nevada from the northern to the southern boundaries of the state; extends to Alaska.

A. circinatum Pursh. Vine Maple, Plate xlv, FIG. 2. Shrub or small tree with slender vine-like branches which root where they reach the ground. Leaves deeply 7-9-lobed, with pointed, sharply serrate divisions, 3-5 inches broad, with roundish outline, with an open sinus at base. Flowers 10-20, in a loose, umbellike corymb, small, with red woolly sepals much longer than the greenish white petals; stamens 8 with filaments woolly at base. Fruit red with wings horizontally spreading, altogether about an inch across. Generally shrubby in northern California but becomes a tree farther north.

A. glabrum Torr. Mountain Maple. Shrub or small tree. Leaves smooth, 2-4 inches broad, with rounded outline, deeply 3-5-lobed, the lobes sharply and doubly serrate, the sinus shallow, surface often beautifully spotted and margined with a red fungus. Flowers in corymbs; sepals and petals greenish yellow, linear; filaments smooth. Fruit with broad erect wings, altogether an inch or less long. Generally shrubby. Not common; found in the upper parts of the Sierra Nevada, extending north to Alaska and south to the mountains of Arizona.

A. Negundo Californicum Sargent. Box ELDER, ('UTheaved Maple. Plate xivi. Leaves compound, with 3 ovate or oblong, acute leaflets, the terminal largest, 3-5-lobed or coarsely serrate; the lateral serrate, sometimes lobed on the outer margin. Staminate and pistillate flowers on separate trees, without petals; the former in clusters on red thread-like pendent pedicels, anthers green; the latter in pendent racenes. Fruit pubecent, about $1 \frac{1}{2}$ inches long, with the wings erect and almost 
parallel. Tree 20-70 feet high. Grows not far from water, generally along streams in the Coast Mountains from northern California to San Bernardino County. In spring the staminate trees in bloom seem draped with pink filmy veils from the numerous flowers which appear before the leaves.

HIPPOCASTANACEA. Buckeye Family.

Leaves palmately compound without stipules. Flowers irregular; stamens more numerous than the petals but rarely twice as many.

\section{AESCULUS. BUCKEYE.}

\section{Plate XlViI.}

Æ. Californica Nutt. California Buckeye. Leaves opposite, palmately compound; leaflets oblong-lanceolate, 3-5 inches long, serrate, with pointed apex, narrowing to a short stem at base, smooth. Most of the branchlets terminate in a large cylindrical thyrse of showy white flowers with a tinge of color from the red anthers. Calyx tubular, unevenly 2-3-lobed; petals about half an inch long with distinct claw; stamens generally 6, conspicuously exserted, at first declined; ovary 3-celled, with 2 ovules in each cell, but generally only 1 maturing and not often more than 1 fruit to a thyrse. When ripe these fruits hang at the ends of long stems of the leafless trees, and are shaped like pears, from which the name 'California pear' is derived. A flat-topped, spreading tree, common from Santa Barbara to Mendocino counties

- and in the foothills of the Sierra Nevada. It is the first tree to turn brown in the dry season, giving the appearance of autumn to the hills and valleys. 
STERCULIACEAE. Sterculia Family.

Leaves alternate. Stamens united into a tube; anthers 2-celled. Fruit a pod. Tree or shrub.

Freirontodendron. Fremontia. 'Slippery Eli.' Plate XlViII.

F. Californica Coville. False Sumpery Ely. Small tree or shrub, with small 3-7-lobed leaves clothed with a rusty, stellate pubescence. Calyx 1-3 inches in diameter, shaped like a wild rose, 5-cleft almost to the base, with bright yellow leathery divisions; bractlets under the calyx, 3-5, small, persistent; corolla wanting; stamens 5, the filaments united to the middle, anthers linear, 2-celled. Pod 4- or 5-celled, splitting open at the top, densely hairy on the inside, persistent for some time after opening. Bark used by the mountaineers as slippery elm. A showy bush when in bloom. Found in both the Coast Mountains and the Sierra Nevada from middle California around Mount Shasta to San Diego.

\section{RHAMNACE E. BuCKTHORN FAMILY.}

Shrubs or trees with simple leaves and small flowers; stamens opposite the petals and inserted with them on al disk; ovary with 2-4 cells, a solitary seed in each cell. Fruit a berry or pod.

RHAMNUS. Coffee BerRy. ('aschri Sagrad.

Plate XLIX.

Leaves alternate, with stipules that soon fall. ('alyx tube urn-shaped, the margin t-5-cleit; petals very small or none. Fruit a berry containing 2 -; stones, ealch shaped like a grain of coffee. 
R. Purshiana DC. CAscara Sagrada. Small tree or shrub, the bark of which is used to make an important medicine. Leaves deciduous, elliptical, serrulate, pubescent on the lower surface, 2-7 inches long, 1-3 inches wide, petals cleft at apex. Fruit black when ripe, containing 3 seeds. In the Coast Mountains from Mendocino County northward.

R. pirifolia Greene. Tree about 20 feet high, with smooth bark and few, spreading branches. Leaves evergreen, oblong to ovate, obtuse at both ends, the apex mucronate, $3 \mathrm{~cm}$. long, $2 \mathrm{~cm}$. wide, entire to glandularcrenate, bright green on the upper surface, yellowish beneath. Berries small, scarlet, solitary in the leaf axils. Santa Cruz Island. Many authorities consider this the same as a shrub which is found from Santa Barbara south along the coast and which has been named $R$. insularis Kellogg.

\section{CEANOTHUS. California Lilac.}

Trees or more frequently shrubs with simple leaves generally small. Flowers blue, white, or lilac, in cymes or panicles; calyx bell-shaped, with colored margins; petals with a small claw, the blade forming a hood; ovary half immersed in the disk, style 3-cleft; fruit a small 3 -seeded pod embraced at the base by the calyx-tube and splitting at the junction of the 3 cells with elasticity sufficient to scatter the hard seeds; the base of the calyxtube remains like a small saucer-shaped disk.

C. thyrsiflorus Esch. Blue Blossoms, Tick Tree, California Lilac. Shrub or small slender tree. Leaves alternate, 3-nerved from the base, 1-21 inches long, less than an inch broad, serrulate, elliptical or oblong-ovate. Flowers fragrant, very numerous, in dense compound 
racemes often forming a thyrse, light blue. Pods smooth, slightly 3-lobed, not crested. Most beautiful when in bloom. Springs up abundantly where the redwood forests have been destroyed by the ax and fire. It is common from Monterey northward.

C. arboreus Greene. Leaves 3-nerved, elliptic-ovate, rounded or slightly heart-shaped at base, obtuse at apex, closely serrate, upper surface dark green, lower white with a close fine down, 3 inches long, Flowers pale blue in an ample thyrse. Pods scarcely lobed, much wrinkled, 3 -crested. Small tree with twigs at first gray, later reddish. Found only on the islands off the coast of Santa Barbara and on Santa Catalina and Santa Cruz islands.

C. velutinus lævigatus $T . \& G$. Honey Dew. Plate L. Small tree; sometimes shrubby. Leaves alternate, large, thick, resinous and shining on the upper surface, aromatic, strongly ribbed from the base, serrulate. Flowers white, numerous, in loose clusters on short peduncles. Pods 3-lobed, slightly crested. Mendocino and Humboldt counties, as a tree; the shrubby form (C. velutinus) common from Santa Cruz County northward.

C. sorediatus $H . \& A$. Blue Blossoms. Plate li. Shrub or small slender tree with spreading branches, rather rigid, somewhat thorny. Leaves alternate, elliptical, glandular on the margins, bright green on the upper surface, much paler on the lower. Flowers deep blue, in very numerous oblong clusters. I'od globose, with erests, and but slightly lobed. In the ('oast Mountains from Santa Barbara northward. Most beatiful when in iull bloom.

C. hirsutus Nutt. Leaves orate to broally elliptical, rounded or cordate at base, $\frac{1}{2}-2$ inches long, clothed 
with appressed long hairs scattered on the upper surface, chiefly along the veins on the lower, 3-nerved and glandular along the margin. Flowers deep blue or purplish, in short-stemmed, loosely flowered clusters about 2 inches long. Pods generally smooth, strongly crested, scarcely lobed. In the Coast Mountains of Central California. More often a shrub than a tree.

C. spinosus Nutt. Plate L. A shrub or small tree 18-20 feet high, the branchlets spiny, reddish brown, widely spreading, angled. Leaves elliptical, 3-nerved, often serrate or dentate on young shoots, rounded at base, obtuse or notched at apex, an inch long, at first woolly, becoming smooth and bright green. Flowers blue, in an open thyrse. Pods smooth, depressed, without crests, and scarcely lobed. In mountain cañons of Santa Barbara, Los Angeles, and Ventura counties, not far from the coast.

C. divaricatus Nutt. Tall shrub or small tree with olive-green, rigid, spreading branches, the glaucous twigs often ending in spines. Leaves 3-nerved, serrulate or entire, gray-green, the upper surface darker than the lower. Flowers pale blue, in thyrsiform clusters 2-3 inches long. Pods smooth, slightly crested but not lobed. Conspicuous on account of the pale color of stems and leaves. Common; found through the Coast Mountains in San Luis Obispo, Santa Barbara, Ventura, Los Angeles, and San Diego counties; also in the foothills of the Sierra Nevada in Kern and Tulare counties, and in the San Bernardino Mountains.

CORNACEA. DOGWOOD FAMILY.

Trees or shrubs, rarely herbaceous. Leaves opposite, simple, entire, without stipules. Flowers in heads sur- 
rounded by a corolla-like involucre or in compound cymes; sepals, petals, and stamens 4; calyx attached to the 1-2-celled ovary; fruit a 1-2-seeded berry or drupe.

\section{CORNUS. DOGWOOD TREE.}

\section{Plate LI.}

C. Nuttallii Audubon. LARGE-FLowered Dogwood. Small tree 20-70 feet high, with smooth gray bark. Leaves obovate, acute at each end, $3-5$ inches long, entire, pubescent. Flowers greenish, in close, buttonlike heads surrounded by 4-6 obovate, white, petal-like bracts, often tinged with cream or red, $2-4$ inches long. Berries bright red, generally few ripening in each head, the rest crowded and abortive. In the Coast Mountains from Monterey to the north where it is most common; in the Sierra Nevada at middle elevations, Yosemite, Kings River; extending to the San Bernardino Mountains in the south and to British Columbia in the north. One of the most beautiful of trees, in the fall gorgeous with the red fruits and brilliantly hued foliage.

The other shrubby species, which very rarely become arborescent, have white flowers in corymbs, reddish stems, and small berries, white or lead-color. C. sessilis has flowers in umbels and black fruit.

GARRYACEA. FRINGE TREE FAMILY.

Evergreen shrubs with opposite, leathery leaves. Flowers grayish green, in pendent catkins from the axils of the upper leaves, generally clustered; the pistillate and staminate flowers on different plants; staminate flowers with 4-parted calyx and + conspicuous stamens on distinct eapillary filaments from bell-like involueres which appear as if strung on a thread; pistillate flowers densely 
clustered, the calyx 2-lobed or wanting; styles 2; ovary 1-celled containing 2 ovules. Fruit a berry about the size of a pea, with a brittle outer covering, pulpy within; contains 1 or 2 seeds; the juice purple.

Garrya elliptica Dougl. Quinine Bush, Silk-Tassel Bush, Fringe Tree. Plate lit. Leaves white-woolly on the lower surface, wavy-margined. Fruit when ripe red-purple but downy, pleasantly acid with a hint of bitterness. The staminate catkins are from 2-5 inches long and resemble fringe. It blooms in December or January and the fruit is ripe in August or September. From the Santa Lucia Mountains in Monterey County to northern California and Oregon. In the north it is frequently a small tree but generally it is only a shrub.

\section{ERICACE五. Heather Family.}

Trees, shrubs, or herbs with simple leaves without stipules. Stamens as many or twice as many as the parts of the corolla; anthers with the 2 cells each opening by a chink at the top. Ovary generally with as many cells as parts of the corolla. Style simple. Fruit a berry, in the plants that become trees.

\section{ARBUtUS'. Madroño, Madrone.}

Plate LIII.

A. Menziesii Pursh. Tree or sometimes a shrub, with trunk and branches smooth brownish red, rarely with bark on one side, the red-brown epidermis peeling off every summer, leaving the trunk and branches for a short time after apple-green. Leaves alternate, thick, evergreen, oblong, entire or serrate, bright green on the

1 Arbutus Arizonica is similar to the above, but with lance-shaped leaves and smaller berries, orange-red when ripe. In the mountains of southern Arizona. 
upper surface, paler beneath; older leaves with margins turned back. Flowers white, honey-scented, in large panicles terminating the branchlets; calyx small, 5-lobed; corolla urn-shaped with 5 recurved teeth at top and honey glands visible on the outside at base; stamens 10 , the anthers flattened, with a pair of horns on the back near the summit. Fruit when ripe a globular scarlet berry with rough warty surface, edible but dry, about as large as a green pea or larger. These trees are most beautiful at all times, in the spring when full of the large panicles of flowers like lilies of the valley, in the fall when gorgeous with the abundant fruit. In the Coast Mountains from San Luis Obispo County northward; also, chiefly as a shrub, in the Sierra Nevada and San Bernardino Mountains.

\section{ARCTOSTAPHYLOS. Manzanita.}

Generally shrubby except when forming trees with short trunk and close round bushy top, the trunk and branches smooth, dark red, the epidermis in most species peeling off in the summer. Leaves alternate, evergreen, generally upright. Flowers white or pink, in racemes or panicles; calyx small, 5-lobed; corolla urn-shaped, white or rose-color, with 5 recurved teeth at top and honerglands at base; stamens similar to Arbutus. Fruit a berry with powdery pulp when ripe and with stony seeds which are all separate or more generally variously coatlescent. The species are not easy to distinguish; almost all may become trees under the right conditions. Those that are most commonly arborescent are given.

A. Manzanita I'arry. Bushes generally isolated and usually found in valleys or on the lower slopes of mountains. Young shoots and leaves ashy gray, becoming 
bright green and smooth in age. Flowers crowded in short pendent racemes or panicles; white or rose-color; pedicels smooth; bracts short and pointed. Berry with several nutlets. In valleys of the Coast Mountains.

A. viscida Parry. Leaves pale gray-green, smooth. Flowers in panicles, erect in bud but pendent later; generally pink, on slender very viscid pedicels; bracts small, scale-like. Berry of several nutlets. Common in the Coast Mountains and the foothills of the Sierra Nevada. Conspicuous on account of its pale foliage. Generally associated in the Coast Mountains with the cypresses.

A. glauca Lindl. Leaves pale green, glaucous, smooth throughout. Flowers in racemes or panicles, pendent in bud and flower. Berries as large as small marbles, viscid, the stone consolidated into a single round nut. From Mount Diablo southward in the Coast Mountains.

\section{OLEACEA. Ash Family.}

Trees or shrubs with opposite leaves without stipules. Calyx with 4 parts; petals 2, 4, or none; stamens 2 ; fruit 1-celled and 1-seeded.

FRAXINUS. AsH.

Plate LIV.

Leaves compound. Flowers perfect, or the staminate and pistillate on separate trees; calyx small, petals 2 or none; stamens 2 with large anthers. Fruit winged from the top.

F. dipetala Hook. \& Arn. Flowering Ash. Small tree or shrub, smooth throughout. Leaflets 5-9, oval or oblong, serrate, with short stems, somewhat separated, 1-2 inches long. Flowers perfect, in open panicles, showy; 
calyx 4-toothed; petals 2, white, as long as the anthers. Fruit an inch long, spatulate, oblong, notched at the top of the wing, pointed at base. Beautiful in spring when in bloom, with its panicles of white flowers. Grows along streams in the inner Coast Mountains and the foothills of the Sierra Nevada.

F. Oregona Nutt. Oregon Ash. Becomes a large spreading tree with dark gray bark. Leaflets 5-7, entire, sessile, usually white-downy but becoming smoother with age, oval to oblong, 2-4 inches long. Flowers without petals; the staminate in short dense clusters, with reddish brown anthers, appearing before or with the leaves from

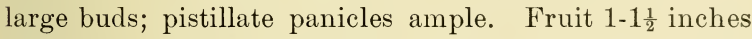
long without the wing at base, the wing becoming broader towards the top. Throughout the Coast Mountains not far from water; in the foothills of the Sierra Nevada, San Bernardino, and San Jacinto mountains; extends north to Oregon.

F. coriacea Watson. Small tree 30 feet or less in height with stout spreading branches. Leaflets generally 5; ovate or oblong, acute at apex, wedge-shaped at base; 2-3 inches long, with distinct stems, 1-2 inches wide; upper surface dark green and smooth, lower paler, serrate on the margin. Fruit an inch or less long, slender, oblong, with the wing rounded or notched at top, as long as the cylindrical seed. Found in the desert region of southeastern California, Cottonwood Creek, growing on mesas and low plains.

\section{BIGNONIACEAE. TRIMPET-VINE FAMHY.}

Trees or shrubs erect or climbing. Leaves opposite or scattered, simple or compound. Flowers large and showy with funnel-form or 2-lipped corolla having is lobes; 
stamens 2-5, generally some imperfect, without anthers; stigma 2-lipped, at the end of the simple style. Pods open in 2 parts; seeds flat, beautifully winged.

\section{CHILOPSIS. Desert WiLlow.}

Plate LV.

C. saligna Don. Shrub or small tree 10-20 feet high, becoming smooth in age. Branches slender. Leaves linear or linear-lanceolate, 4-6 inches long, the lowest opposite or whorled, upper scattered. Flowers showy, in short racemes at the ends of branchlets; calyx closed in bud, bursting irregularly when the flower opens; corolla white tinged with pink or purple, funnel-form, the lobes crisped on the margins, somewhat 2 -lobed and with curving tube, 1-2 inches long; stamens 5, with anthers 4, one without. Pods long, linear, pointed, cylindrical, the 2 valves opening contrary to the partition; seeds narrow, in 2 or more series on each side of the partition, the wings consisting of long silky hair-like fringe. Mohave Desert; Inyo, Riverside, and San Bernardino counties; Arizona, Nevada.

RUBIACEA. Madder Family.

Leaves simple, opposite or whorled. Calyx and corolla 4-lobed, attached to the ovary; stamens distinct, alternate with the lobes of the corolla and borne on its tube. Ovary 2-5-celled.

Cephalanthus. Button Bush, Button Willow.

Plate LVI.

C. occidentalis $L$. Generally shrubby, growing near water. Leaves like those of willows, 3-5 inches long, opposite or more often whorled. Flowers fragrant, 
cream-color, in a dense round head about an inch in diameter; calyx 4-toothed; corolla with long, slender tube and small 4-cleft border; stamens short; style long, conspicuous, with a cap-like stigma. Pods when ripe splitting from the base upwards into 2-4 close 1-seeded parts. Common along streams throughout the state except near the coast and upper elevations in the mountains. Arizona.

\section{CAPRIFOLIACE正. Honeysuckle Family.}

Leaves opposite, without stipules. Flowers regular or irregular; calyx 5-toothed, attached to the inferior orary; corolla 4- or 5-cleft; stamens distinct, as many as the corolla lobes and alternating with them. Ovary 2-5celled. Fruit a berry or dry pod.

\section{SAMBUCUS. ELDER.}

Plate LVII.

Shrubs or small trees with pinnately compound leaves having 5-11 serrate leaflets. Flowers small, white, in large compound cymes; corolla wheel-shaped or open urn-shaped with 5 lobes; stigmas and cells of the ovary 3-5. Fruit a berry containing 1 seed, really a small drupe.

S. glauca Nutt. Blue-BerRien Eldek. simall tree or shrub, the trunk slender, the top spreading. Leaflets $3-9$, ovate or lanceolate, smooth and leathery. Cymes ample, flat, much branched. Berries blue-black covered with a bloom and sometimes appearing whitish. Common throughout the state and extending to Oregon, Idilho, and Nevada.

S. callicarpa Greene. Ren-berken Elder. (ienerally shrubby but sometimes becomes a small slender tree. 
Leaflets obovate or oblong, pointed, 2-7 inches long, smooth on the upper, pubescent on the lower surface. Cymes large, ovate. Berries red, occasionally yellow. Along streams and in ravines in the Coast Mountains of California. 


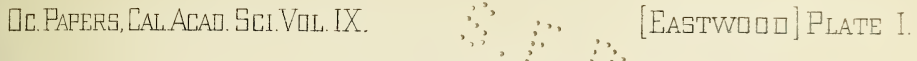

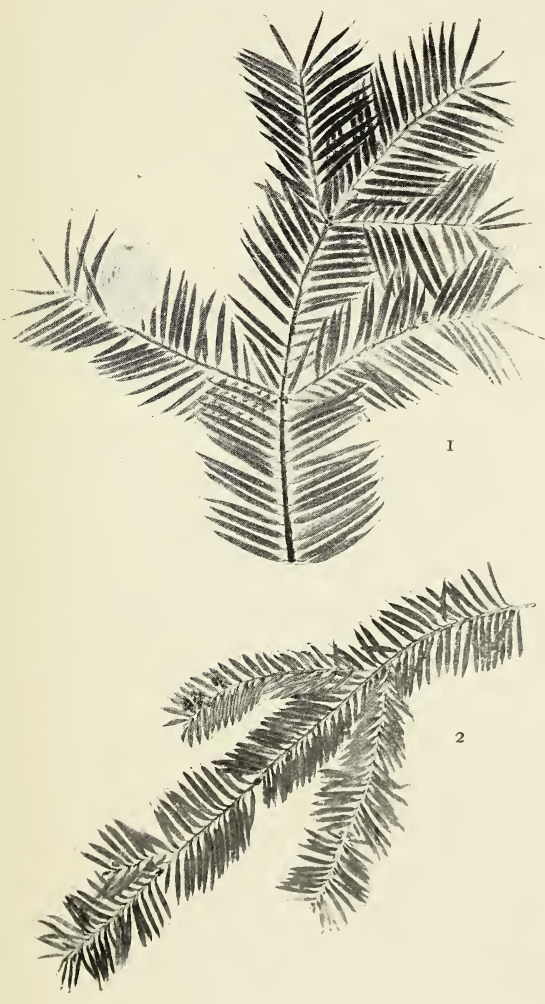

Fig. $x$. Tumion Californicum Gireene

Hig. 2. Tarms brerifoliu Nutt. 

ac Paperg, Lal.acad. Sci.Val. IX.

[EASTWOQD]PLATE II

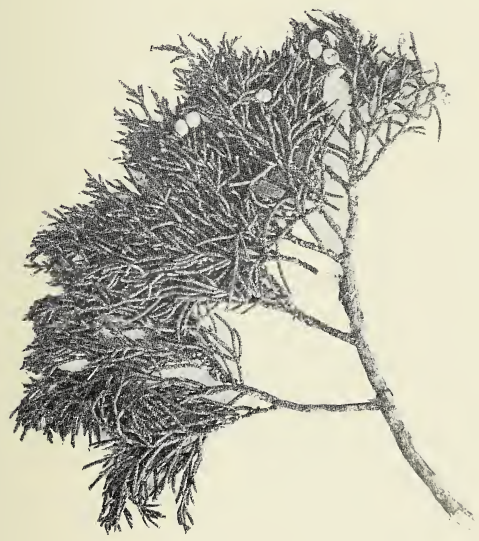





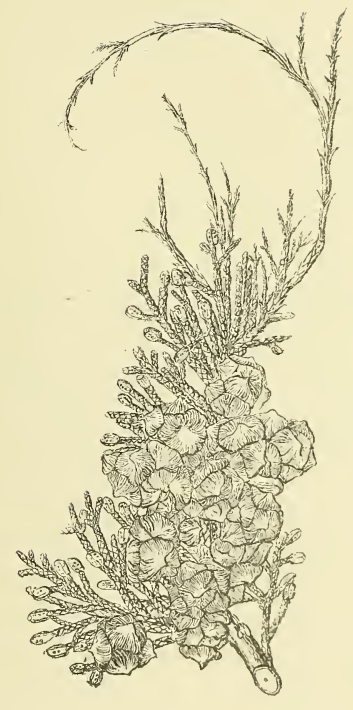

Cupressus (ioveniana Gordon. 



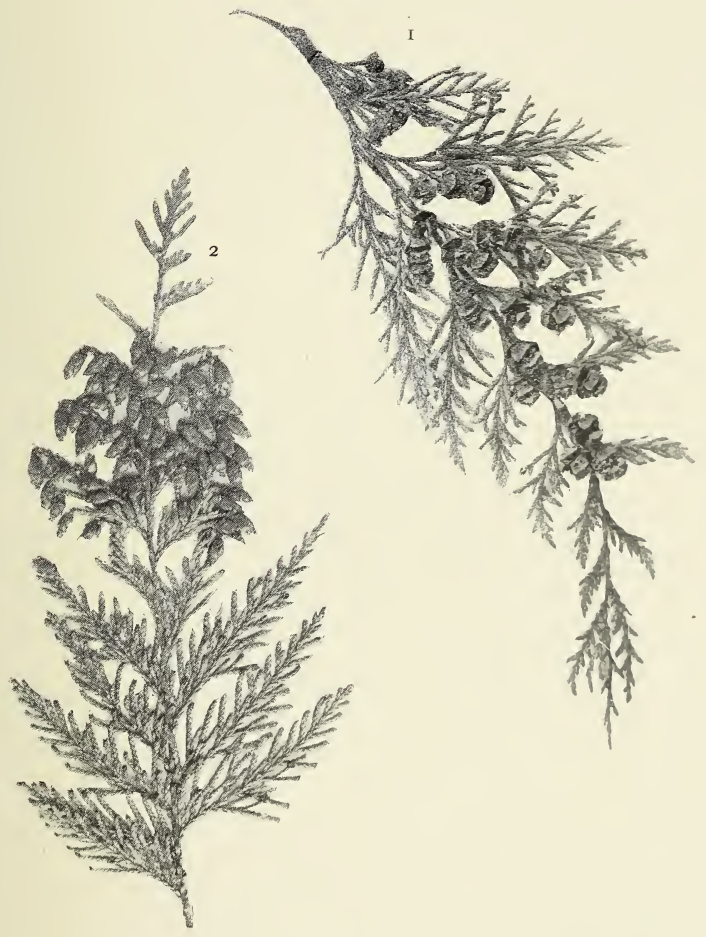

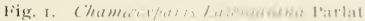





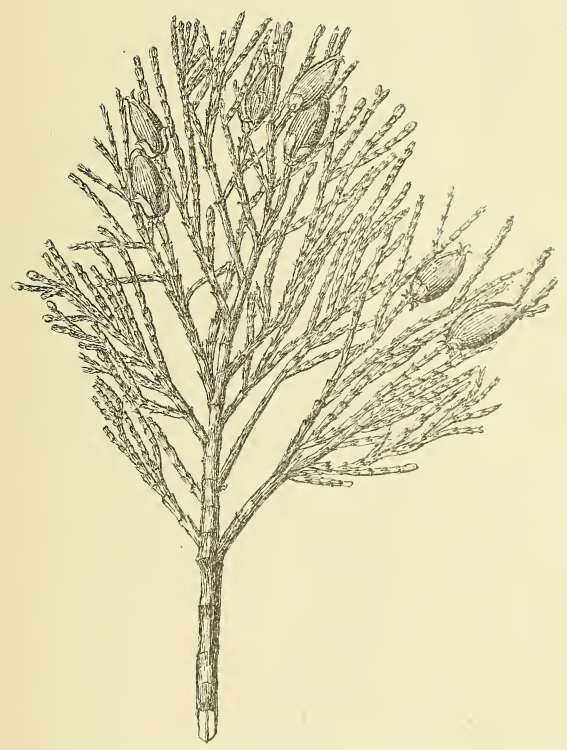



De.Papers, Cai.ACad. Sci.Vul. IX.

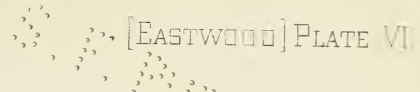

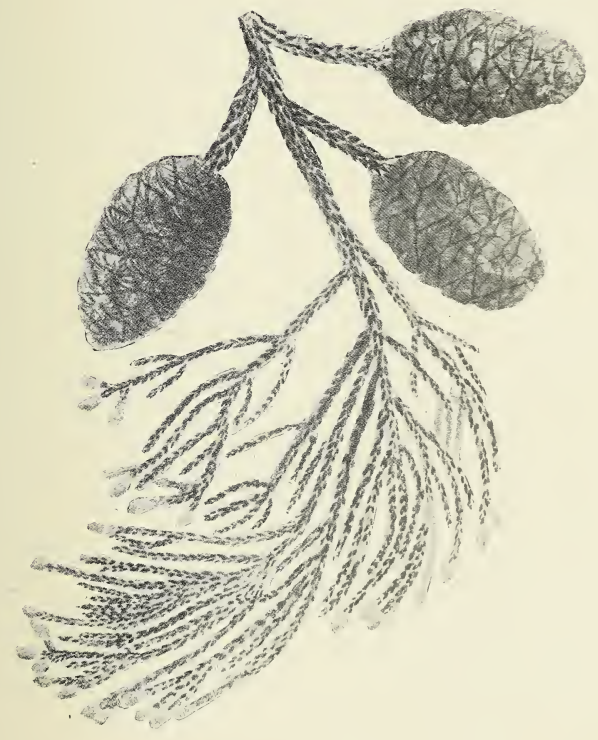




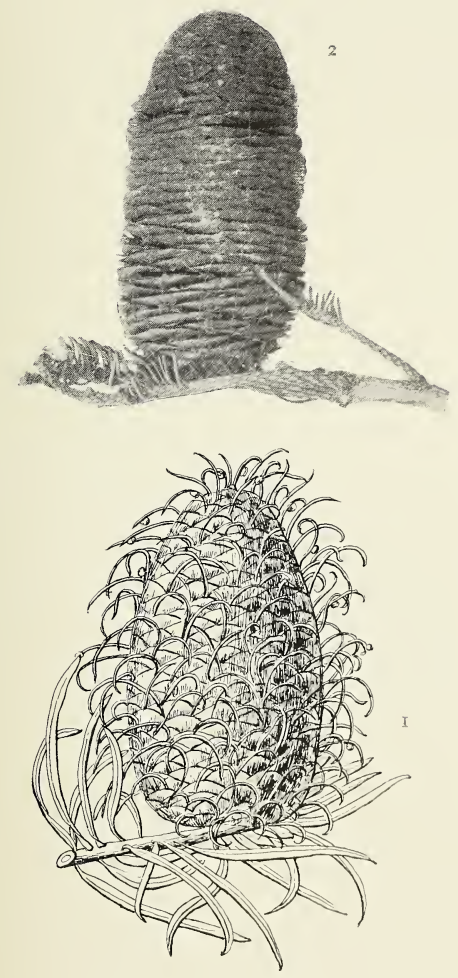

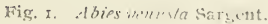

Tig. 2. 4bies magnition Mirr. 

Dc. PApers, Lal Acad. SEI.VDL. IX.

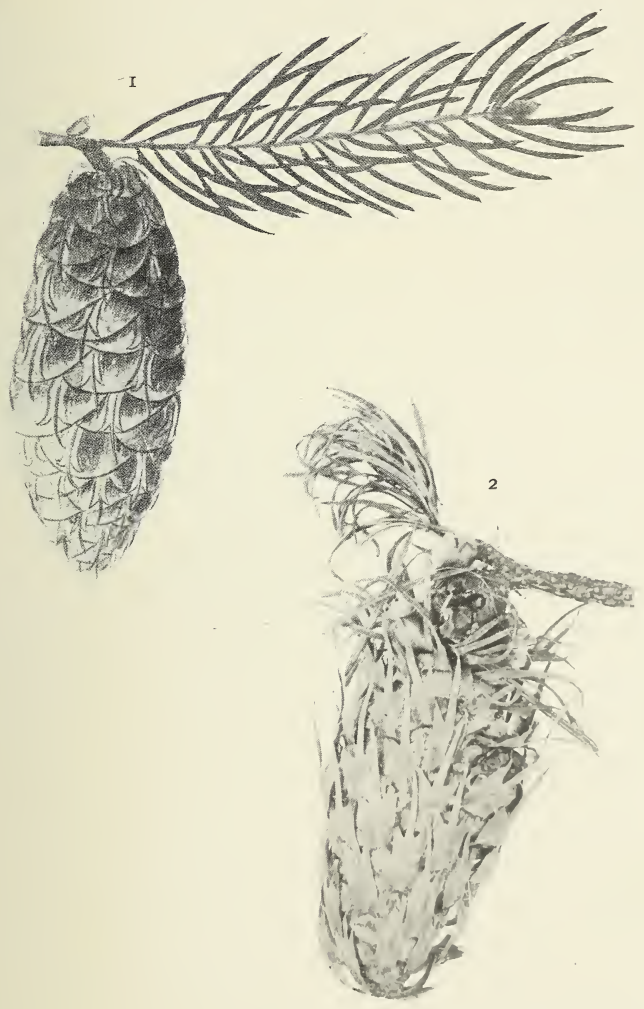

Fig. ז. Pseudotsuga murronata Sudworth

Fig. 2. Psendotsuga macrocarpa I, cmmon. 

Dc. Papers, [al. Acad. Sci.Val. IX.

\{EAstWugd $\}$ PLATE IX.

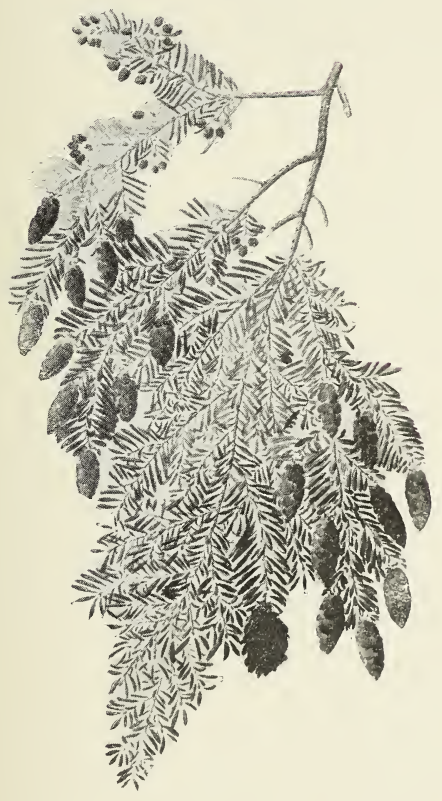



uc. Papers, Cal Araj. Sci Vul. IX.

[TAETWUDU]PLATE K.

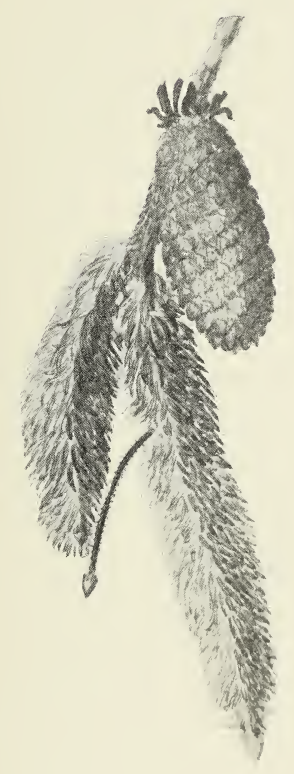

Picea Sitchensis Cart. 

Ge Papers, Lal Acad SciVgl. IX.

[EASTWU⿴囗十] PLATE XI.

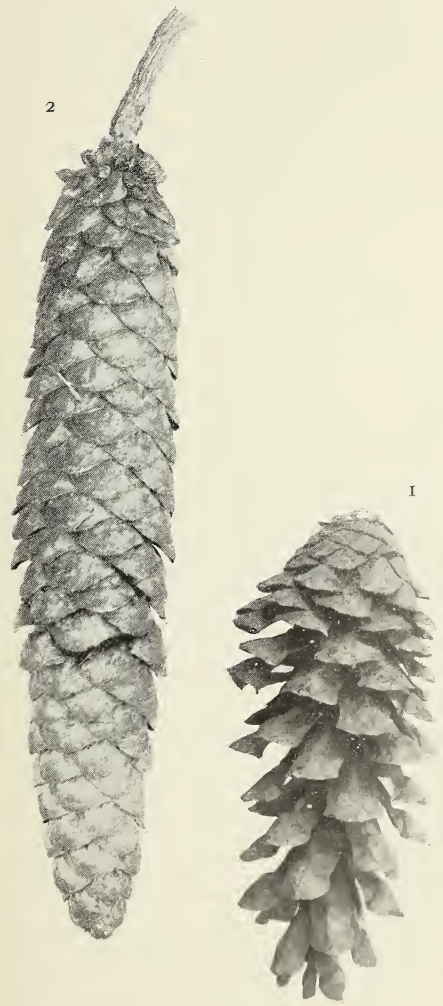

Fig. r. Pinus monticola Doug1.

Fig. 2. Pinus Lambertiana Dougl. 

Ic Papers, [al. Acad. Sci.Vul. IX.

[EAsTWugu| Plate XII

$\because$

2

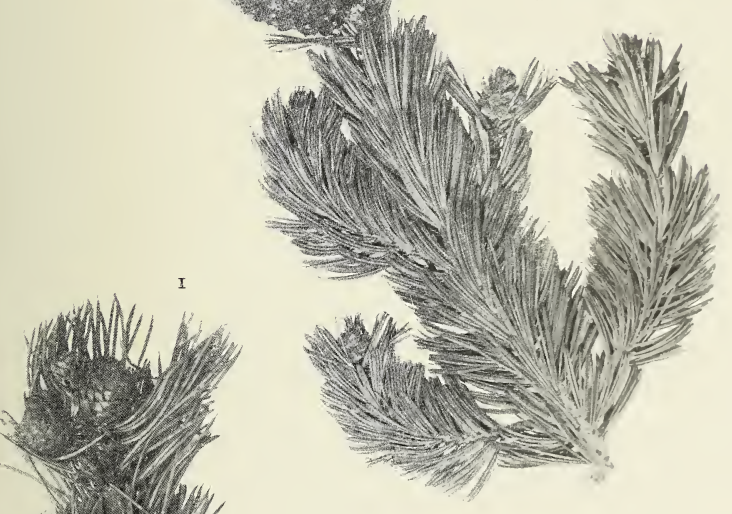

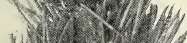

1)

19.1)

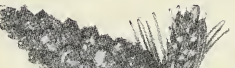

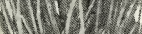

Al $1(1)(1)$.

AII)

(I)

)

N1)

t. 

घc. Papers, Lal.Acad. SEI.Vgl. IX.

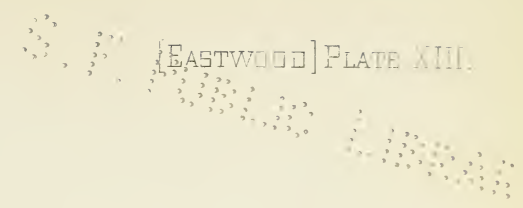
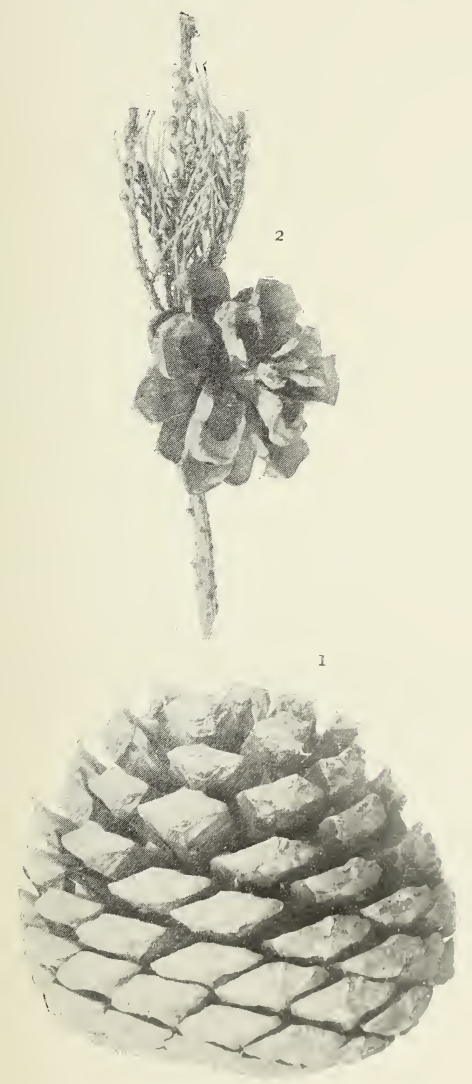

Fig. x. Pinus Forresana Parry.

Fig. 2. Pinus monophylla Torr. N Lirem 


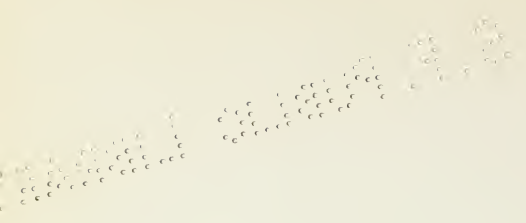



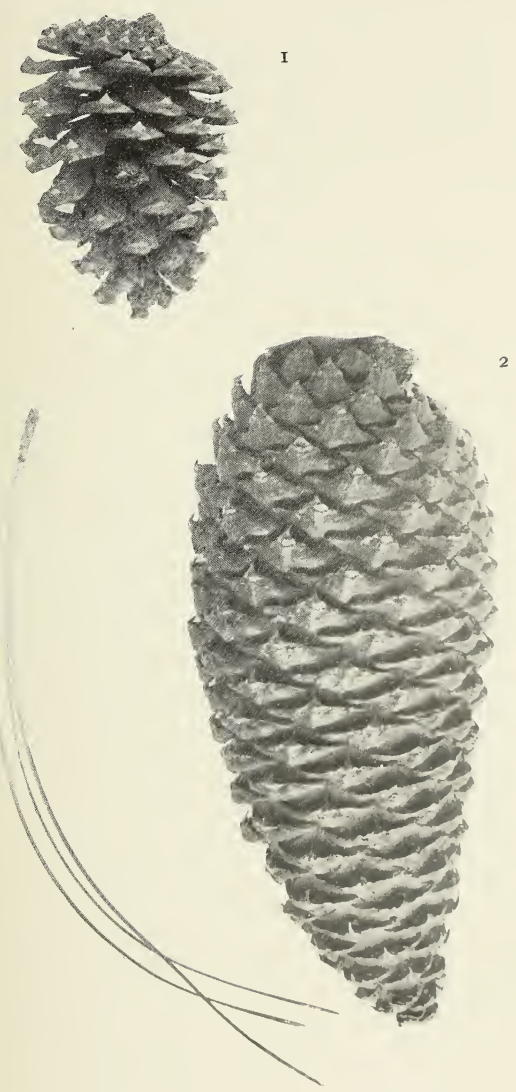

Fig. I. Pinus ponderosa Dougl.

Fig. 2. Pinus Jeflevi Murr. 



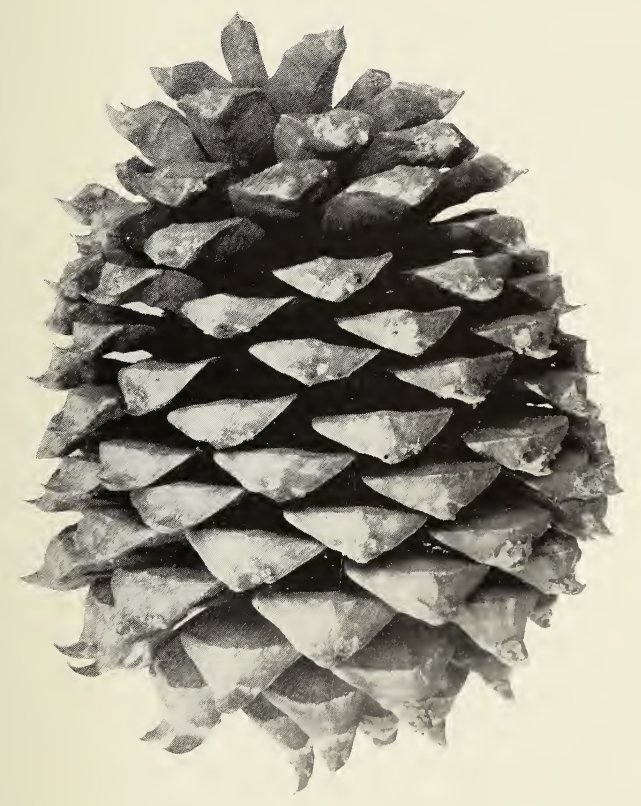



De Papers, LaL.ACAD. SCI.VDl. IX.

[EASTwugu] Plate XVI.

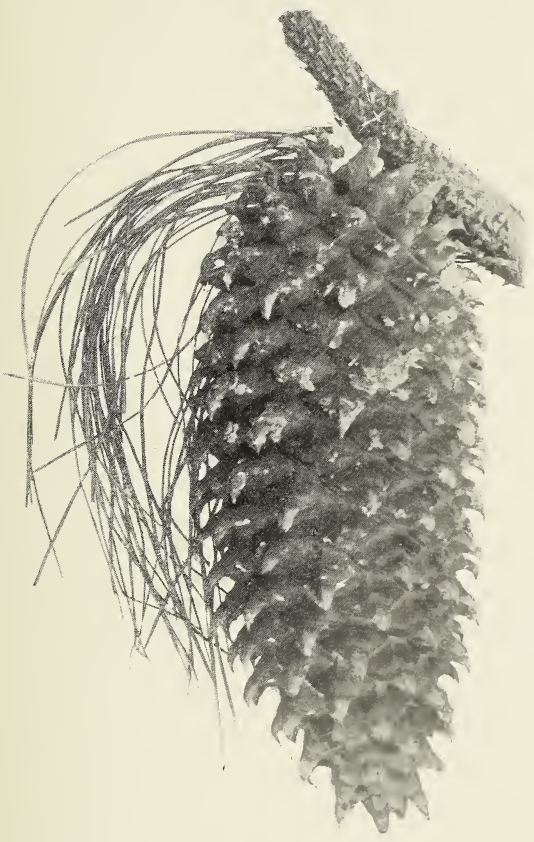




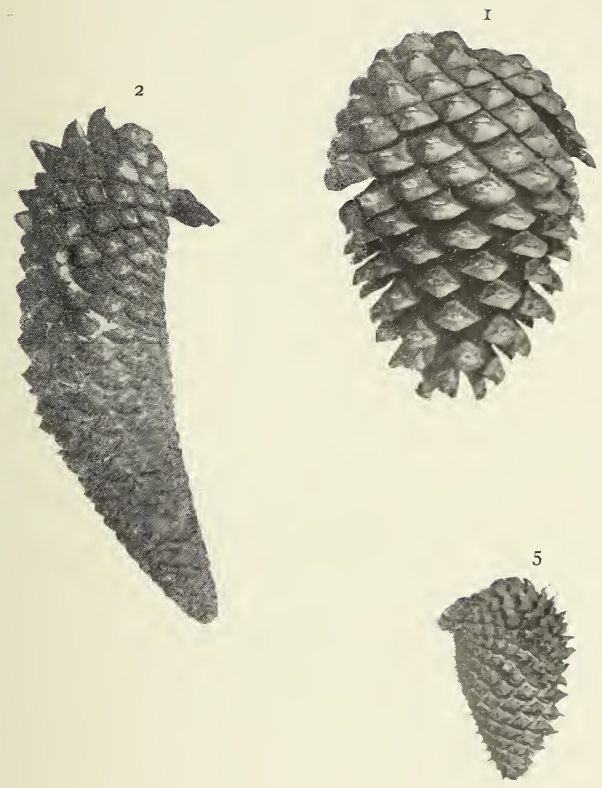

4
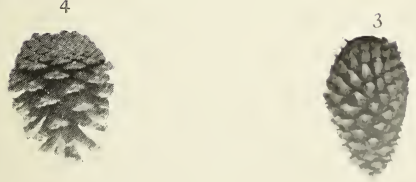

Fig. I. Pinus radiata Don.

Fig. 2, Pinus attenuata I,emmon,

Fig. 3. Pinus contorta Dougl.

Fig. 4. Pinus Murrayana Murr.

Fig. 5. Pinus murionta bon. 



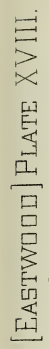

$$
\because \because, \quad \therefore \because \because \because, \cdots
$$$$
\therefore \therefore \therefore \because
$$

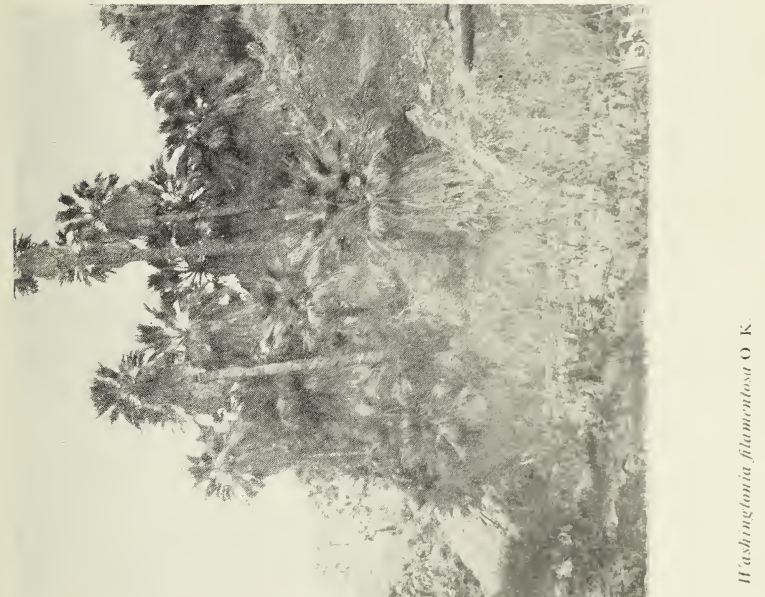

岸 



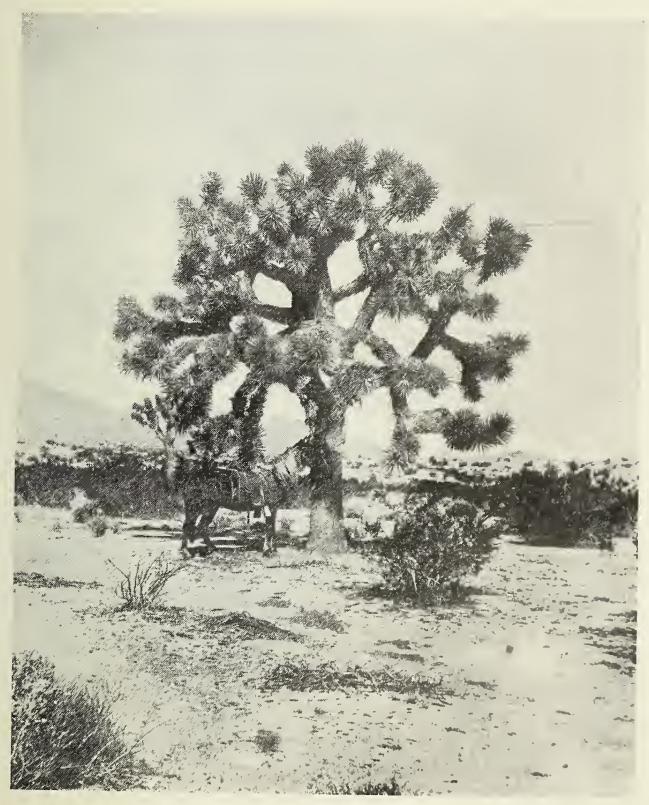

Cleisloyucca arborescens Trelease.

From Coville, United States Department of Agriculture 



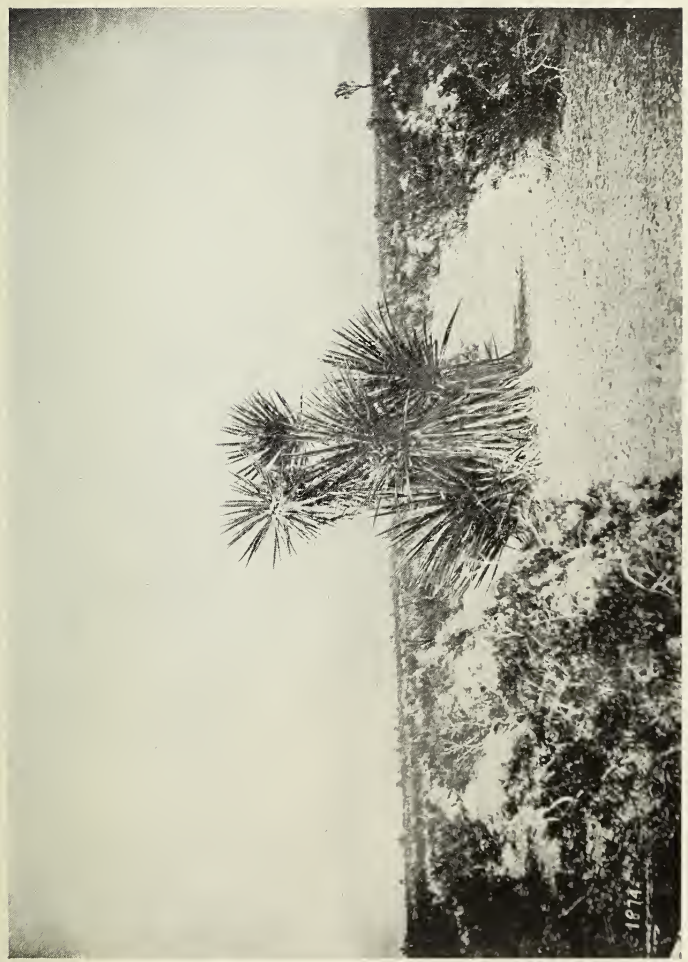





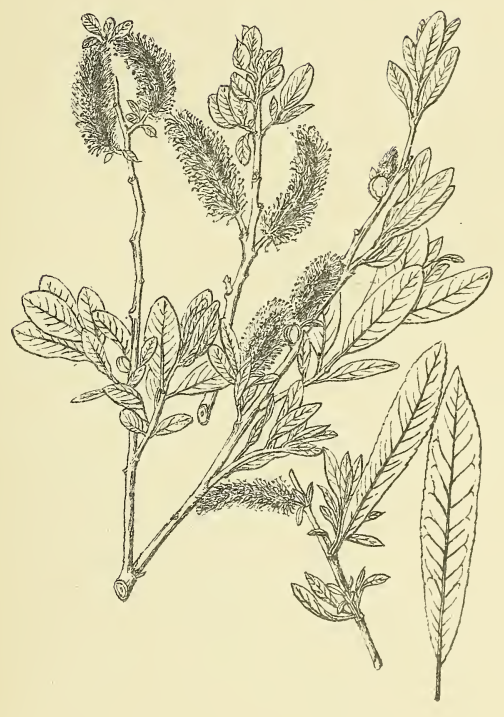



De. Papers, Cal Acad. Sci.Vul. IX.

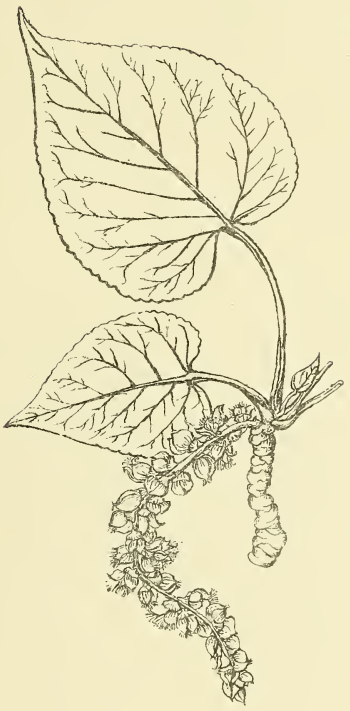





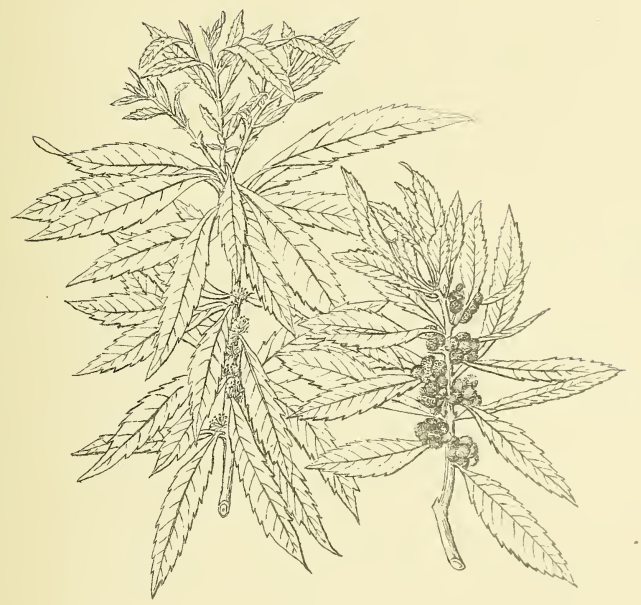



De. Papers, Cal. Acad. SEI.Vul. IX.

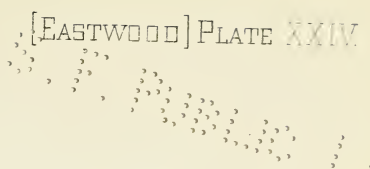

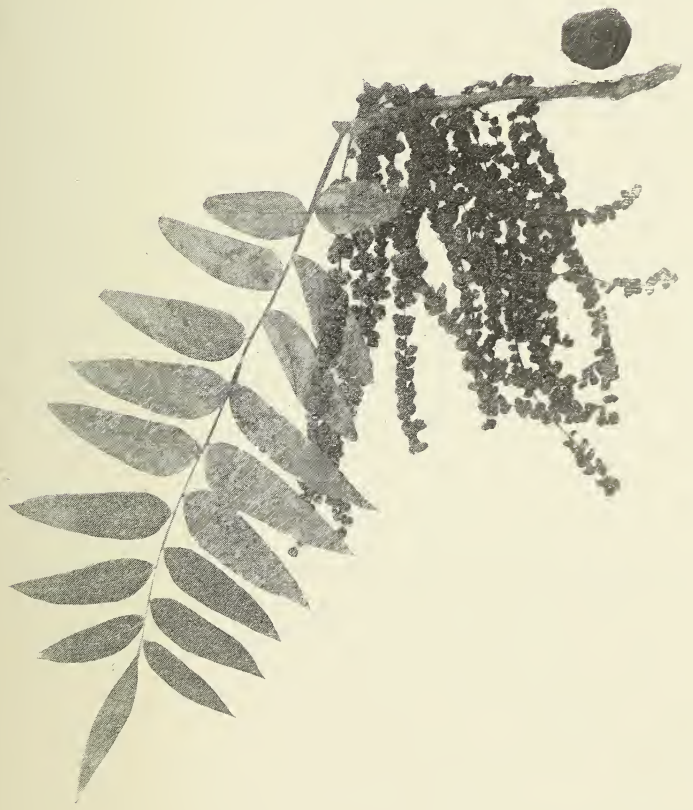



ac Paperg, Lal.Acad. Sei.Vul. IX.

[EASTw

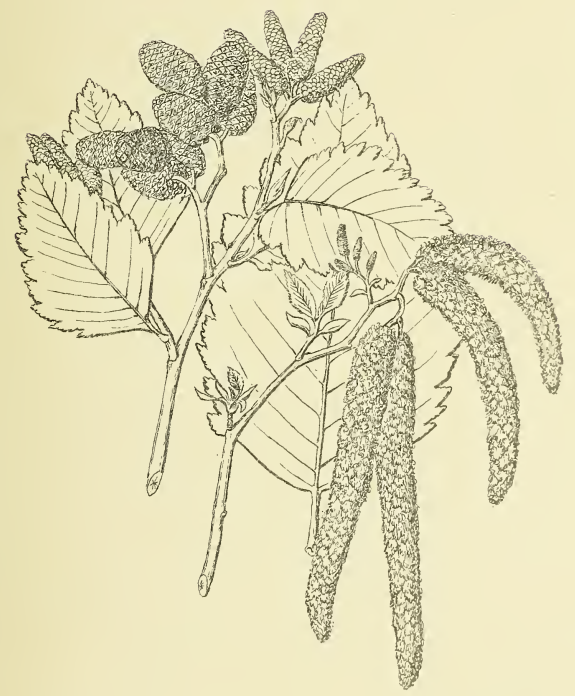





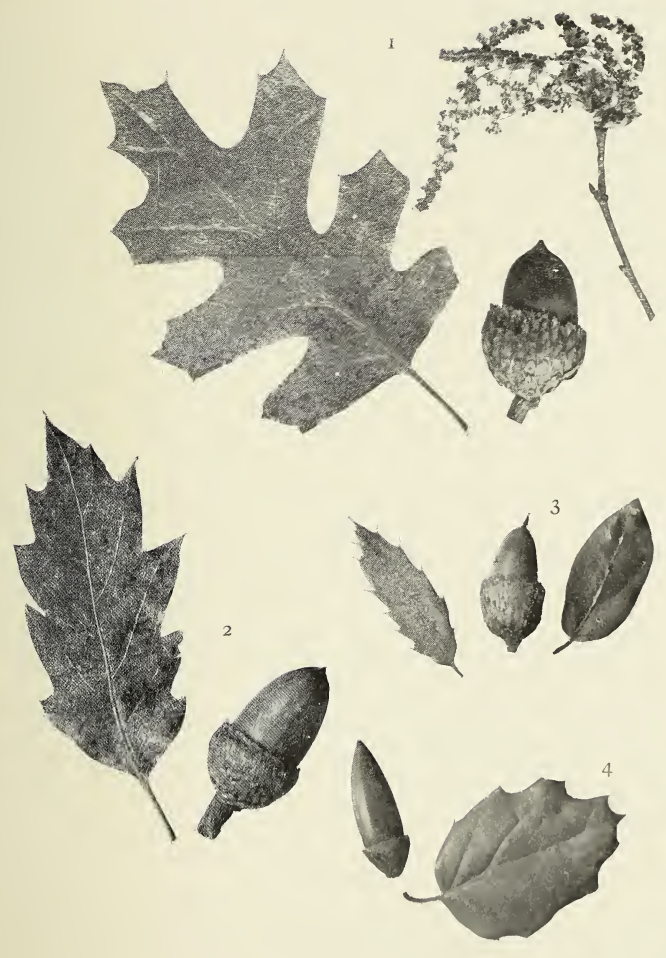

Fig. x. Quercus Callomica Cooper,

Fig. 2. Quercus Morrluss Kellogg

Fig. 3. Querens Wristimini A. IC.

Fig. 4. Cuercus arrifoliu Nee. 


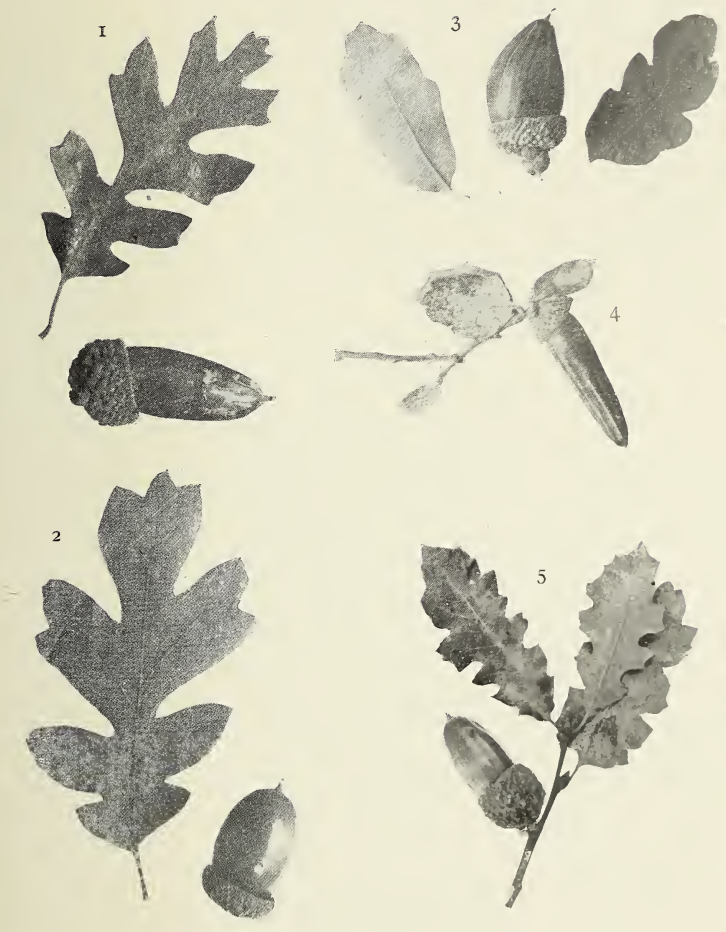

Fig. I. Quercus lobala Nee.

Fig. 2. Quercus Garryana Dongl.

Fig. 3. Cuercus Dorglasii H. \& A.

Fig. 4. Qnercus Ilvordiana Yastwoud.

Fig. 5. Querus Maclonaldi Grene. 


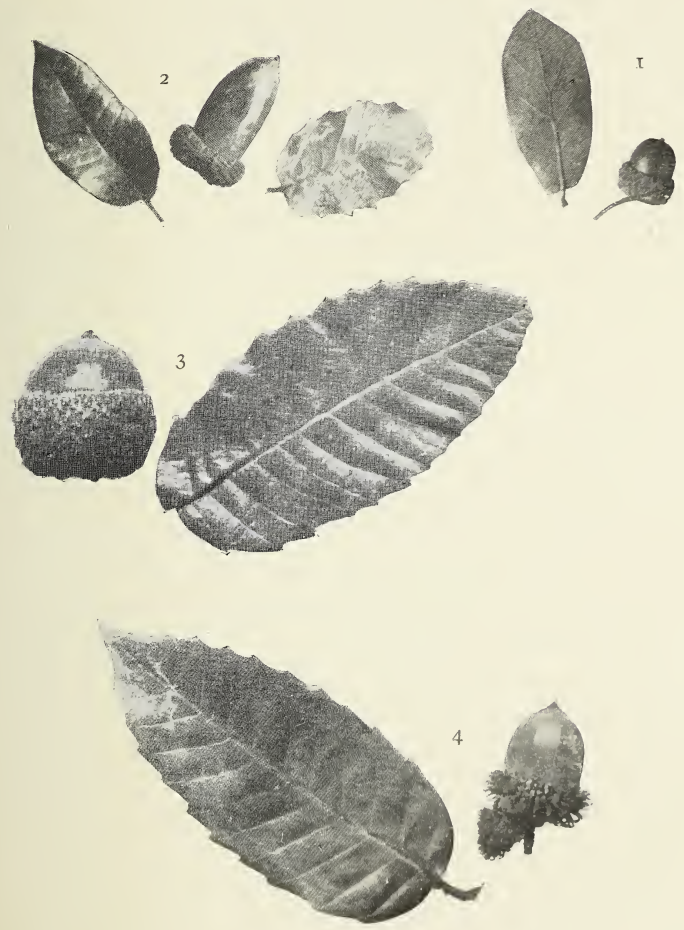

Fig. I. Quercus Lngelmanni Greens.

Fig. 2. Quercus chrysolepis 1,iebm.

Fig. 3. Quercus tomentellat Lugehn.

Fig. 4. Ouereus densillona llook. S Aru. 



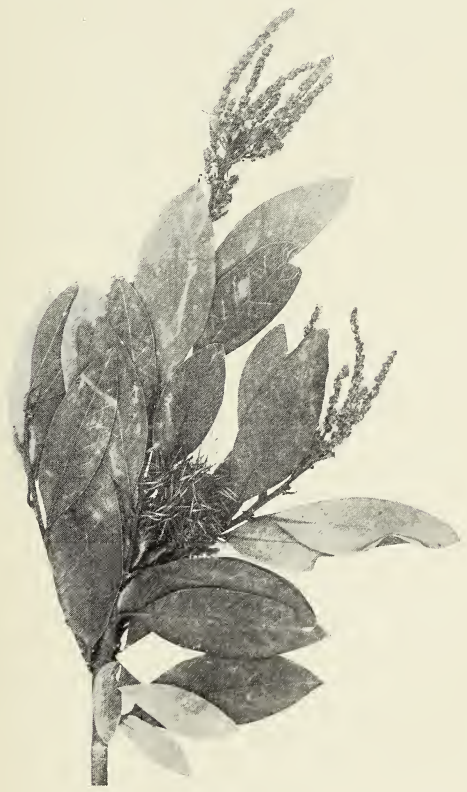





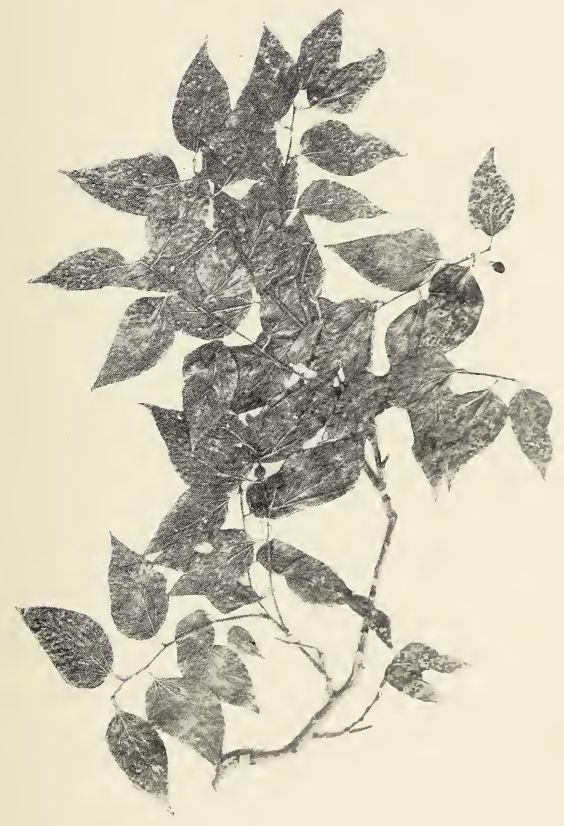



qu. Papers, Cal Acad. Sci.Vul IX.

$$
\therefore \quad, \quad, 3 \text { EASTWOQD]PLATE }
$$

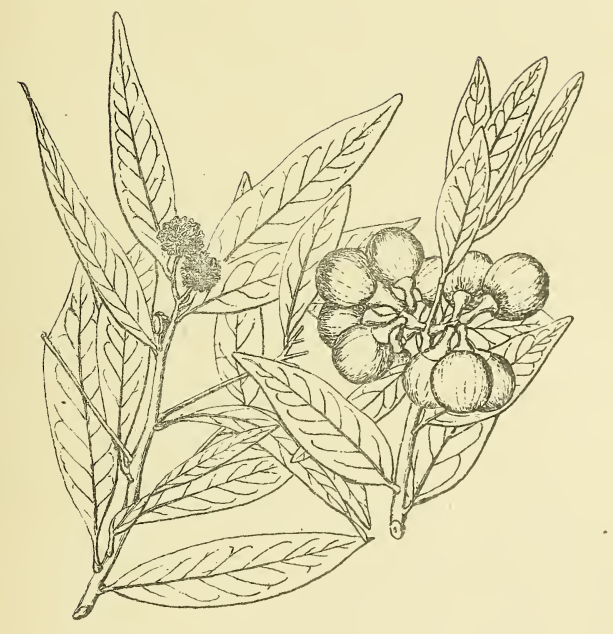



De Papers, Lal Acad. SEIVql. IX.

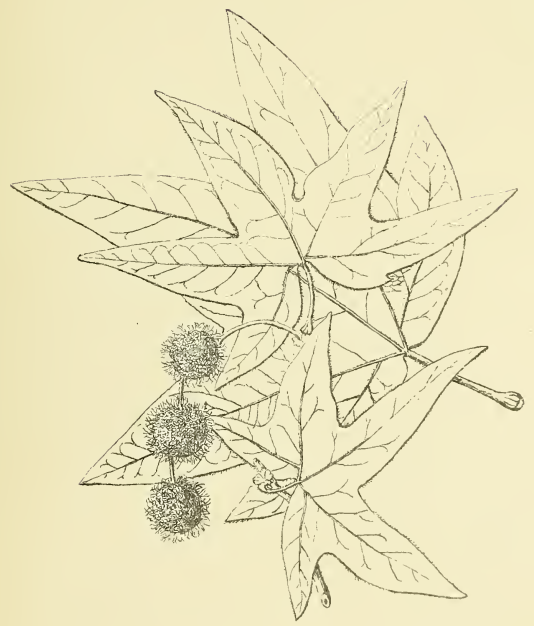





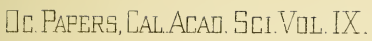

[EAȘTWDOD] PLATE XXXUII

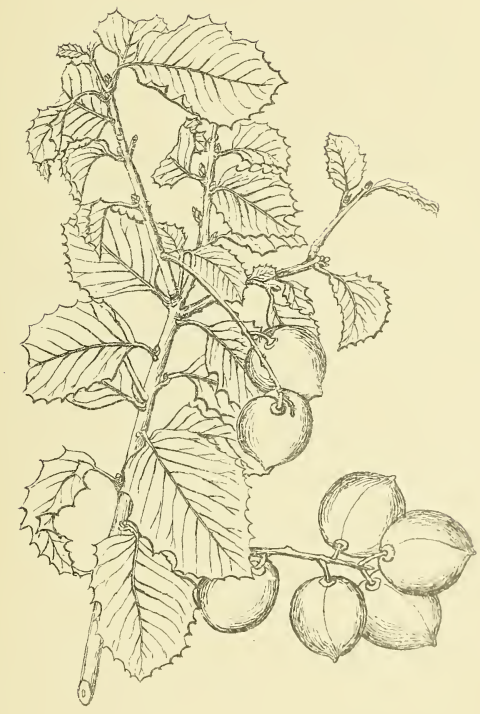



ac Papers, Lal Acaj. Sci Vgl IX.

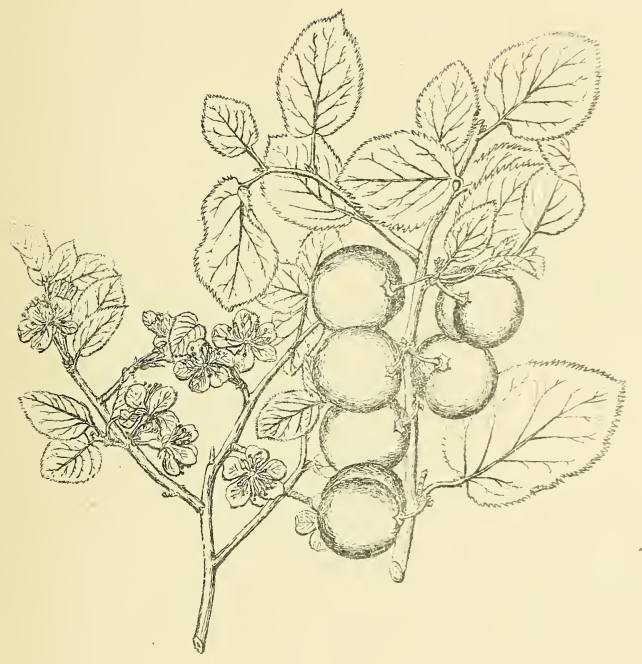





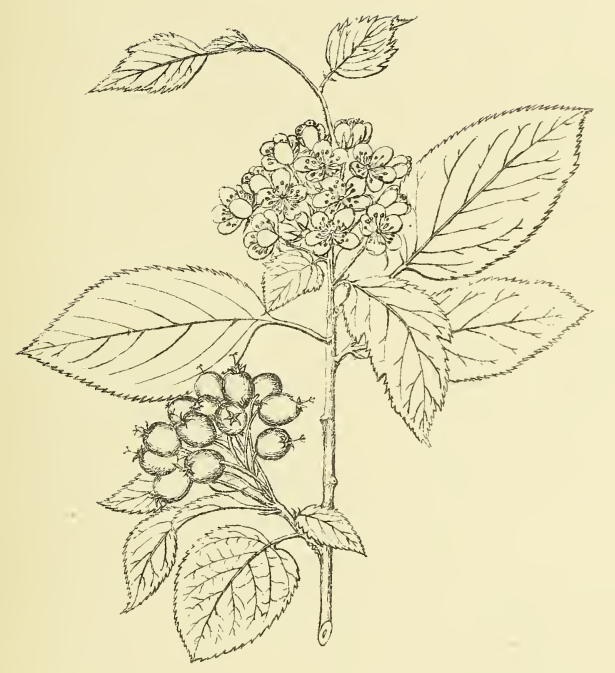





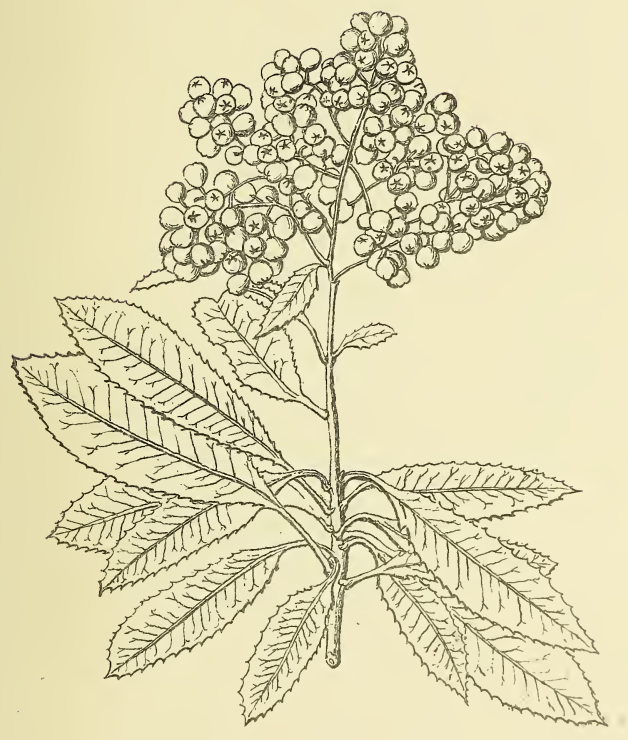





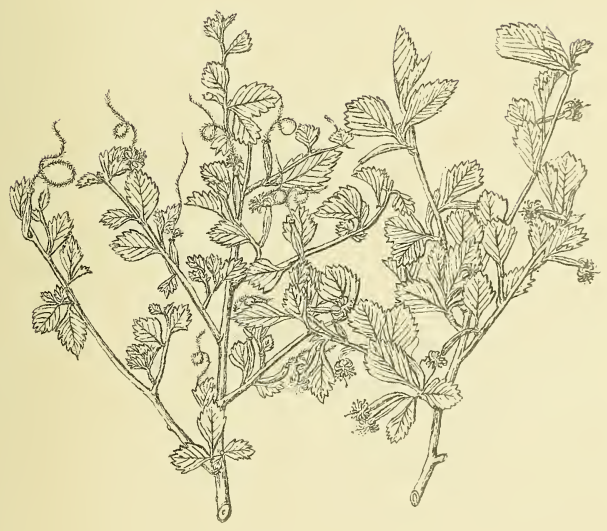





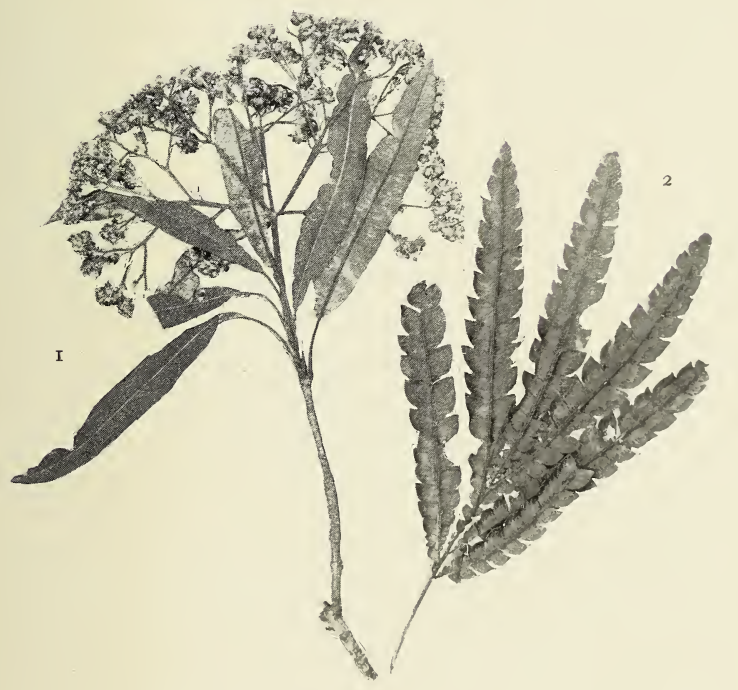

Fig. x. Lyonothammus fonsibundus Gray.

Fig. 2. Lyonothamnus asplenifolius (ireenc. 



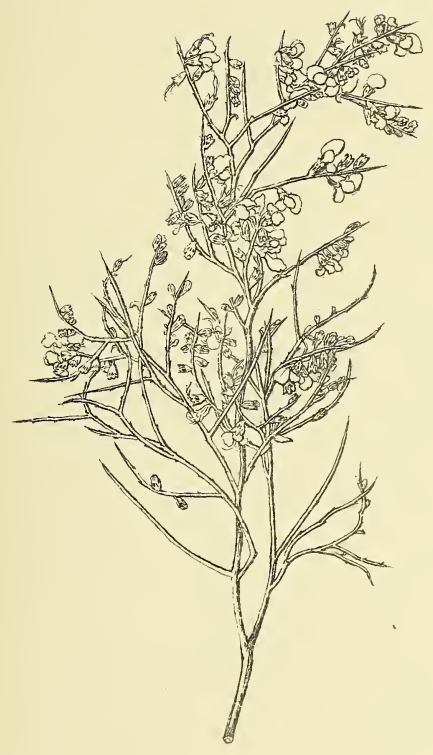





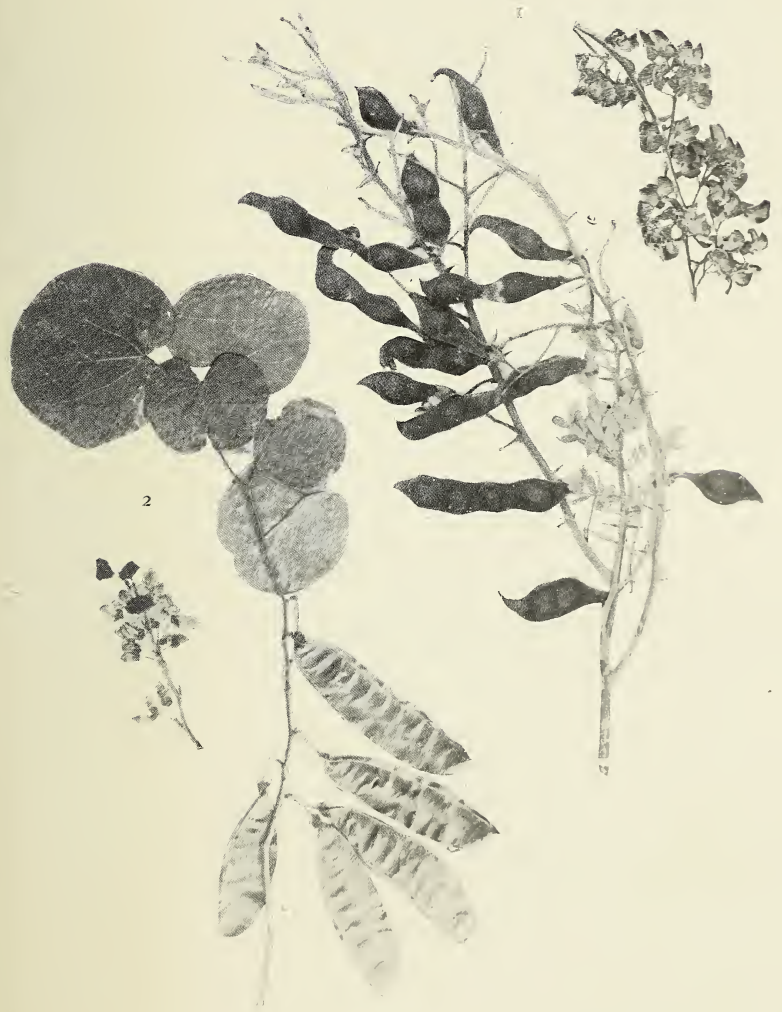

Fig. x. Olneya Tesola Gray.

Fig. 2. Cercis orcidentalis 'xor 



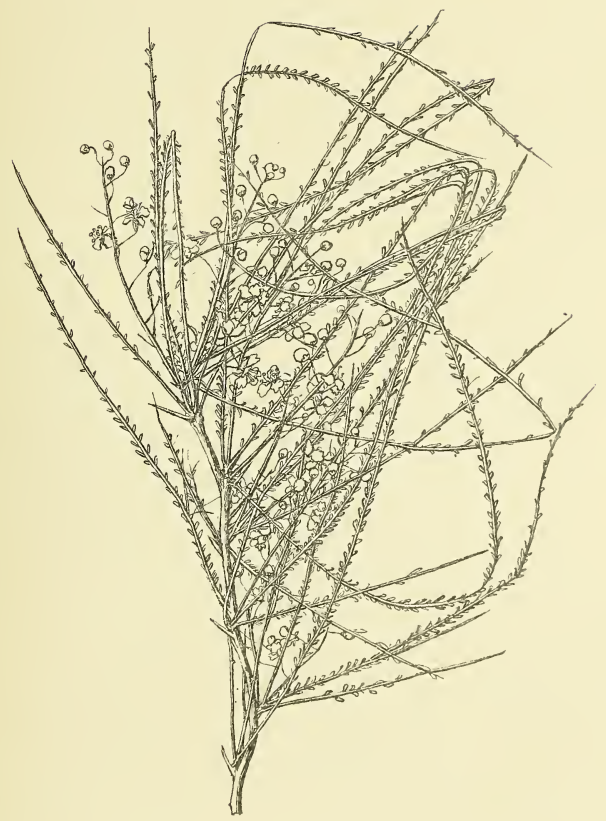



De. Papers. Eal Acad. Sci.Vtal IX
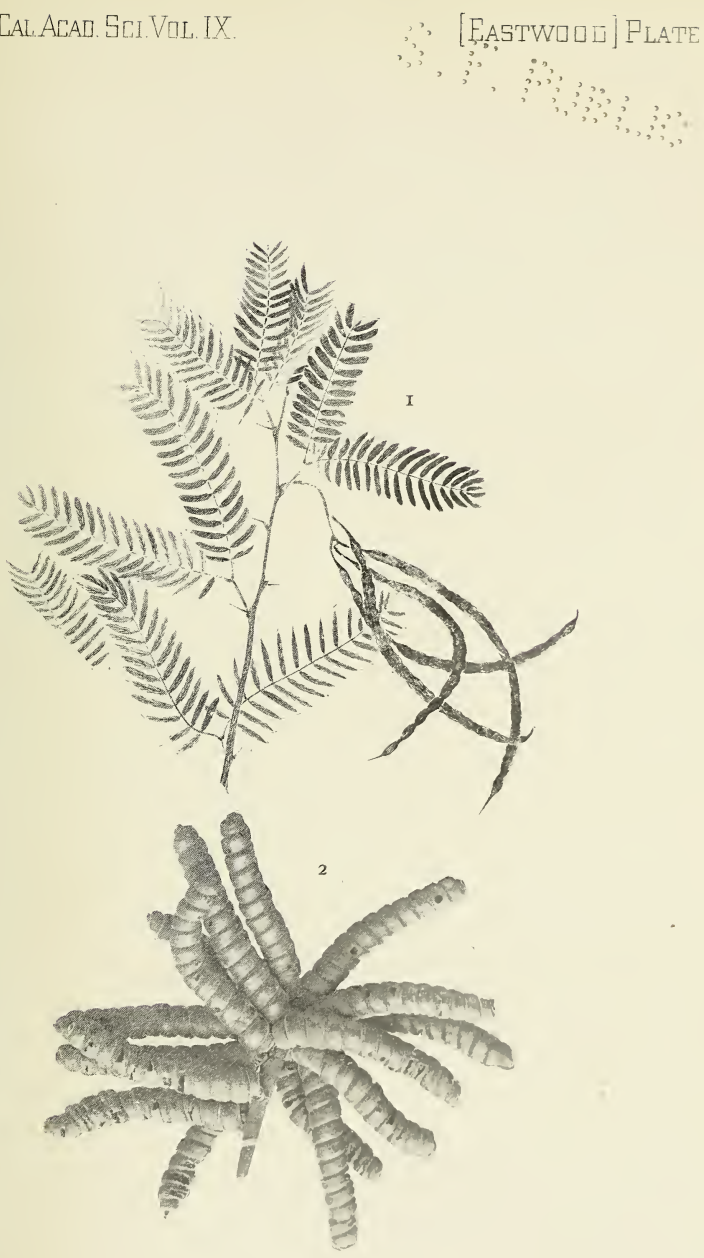

Fig. I. Prosopis juliflora DC.

Fig. 2. Prosopis pubescens Benth. 

De Papers, Cal acad. Sci.Vul. IX.

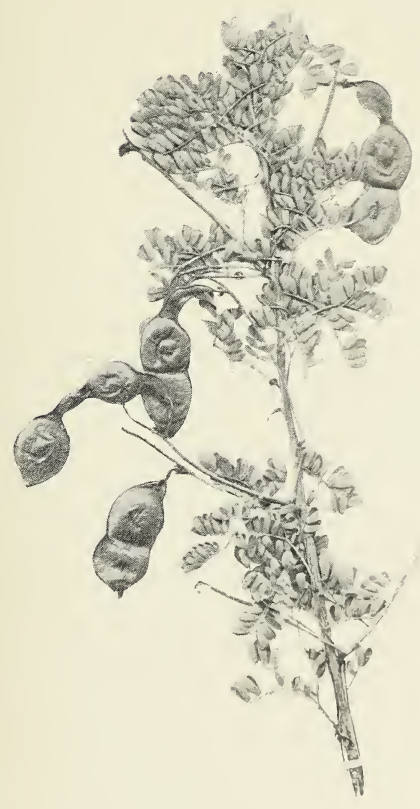


$+$ 


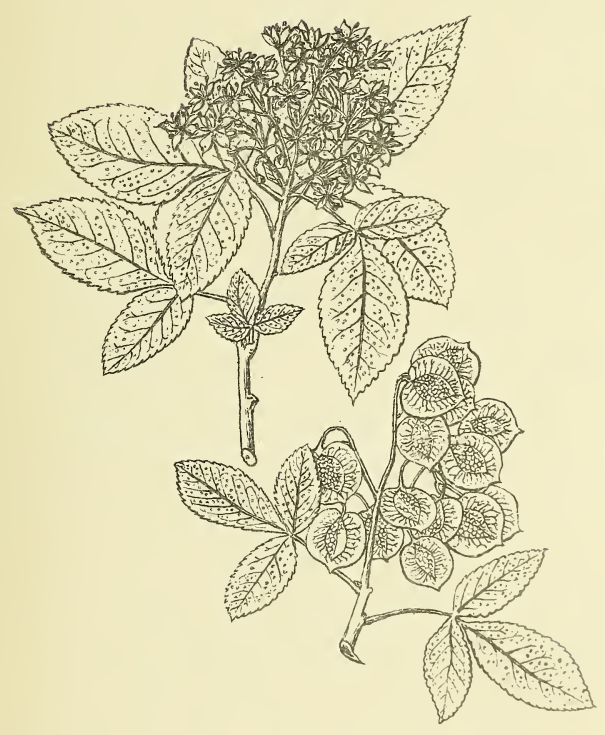



[c. Papers, Cal.Acad. Sci.Vul. IX.

[EAGTWDGU] PLATE MLV.

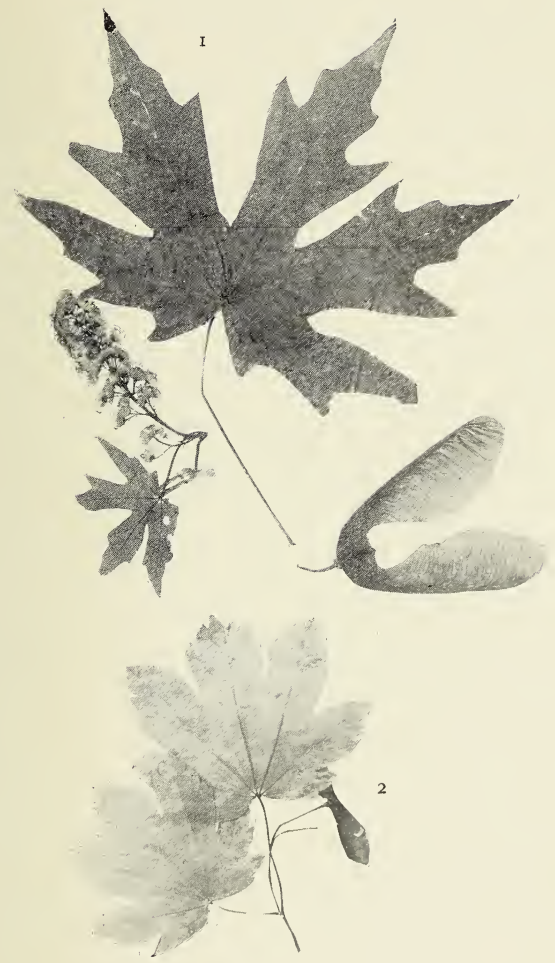

Fig. I, Acer macrophylhem P'ursh.

Fig. 2. Acercircinatum Pursh. 

ac Paperg, Cal.Acad. Sci.Vol. IX.

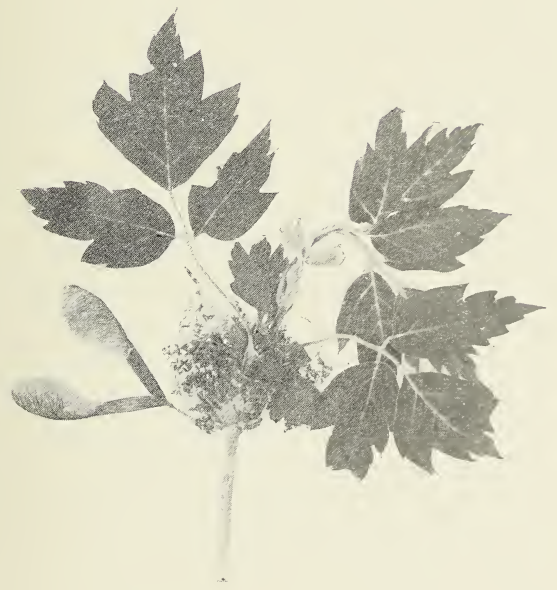



Gc. PApers, CAl. Acad. SEIVDl. IX.

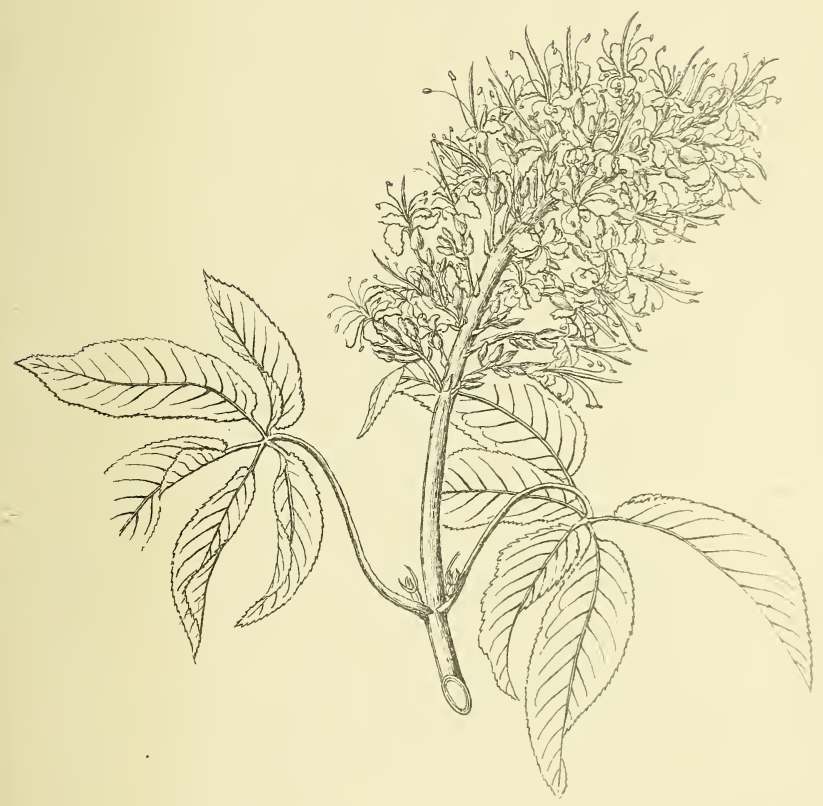



De. Papers, Cal Áad. Sei.Val. IX.

[Eastwoud] Plate XiViil.

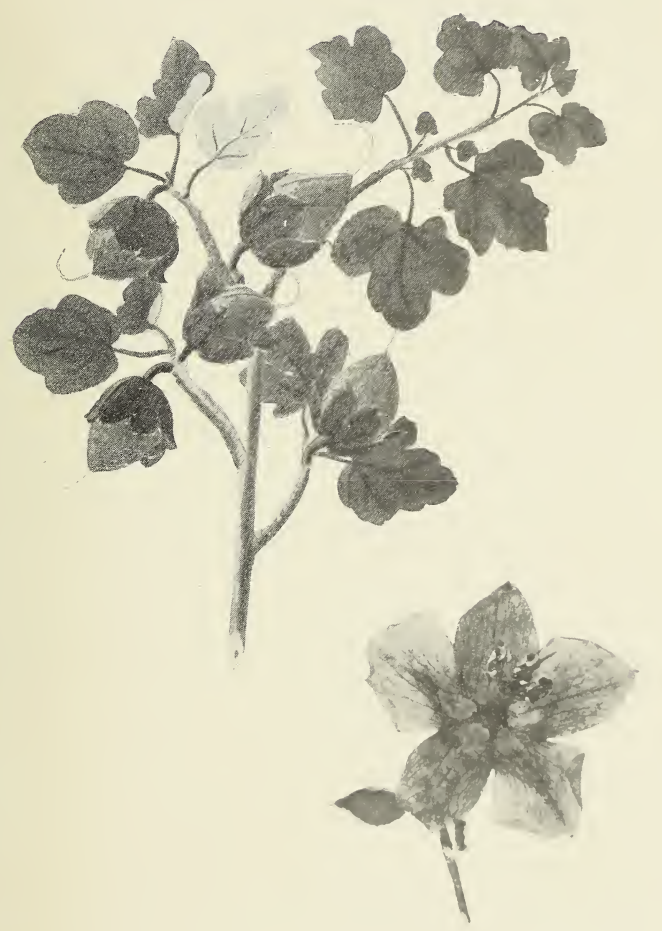



De Papers, Lal Áad. SEi Vul. IX.

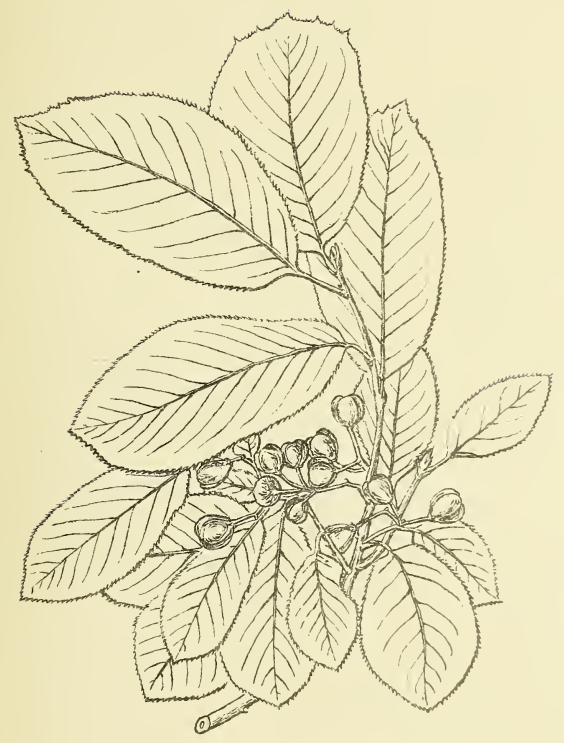



口c. Papers, Cal. Acad. Sci.Vol. IX.

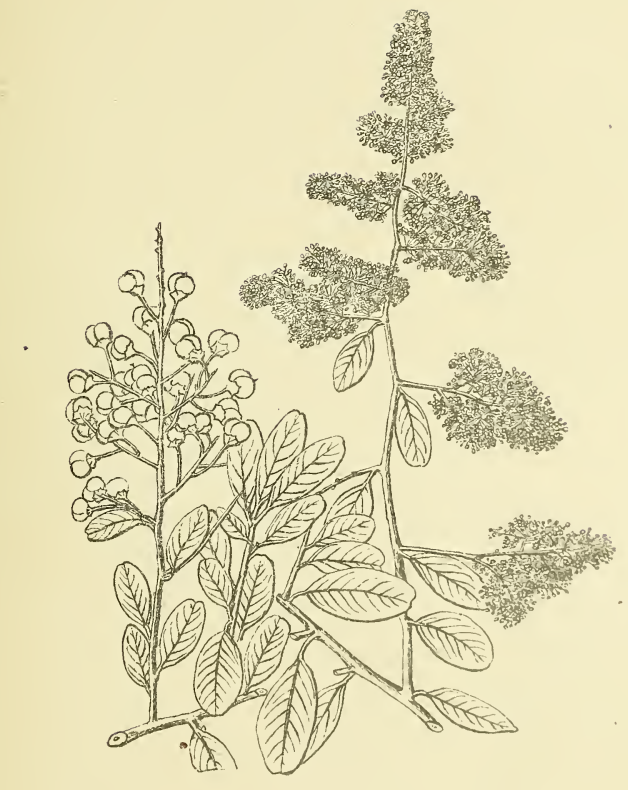





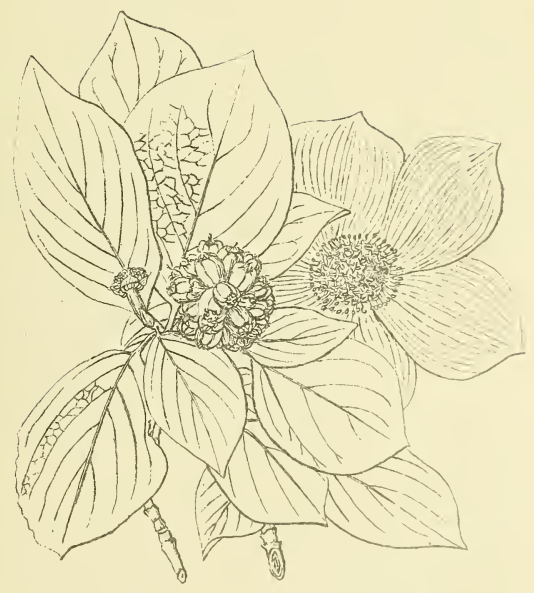



Dc. Papers, Lal.Acad. Sci.Vul. IX.

[EASTWugu]Plate Lil.

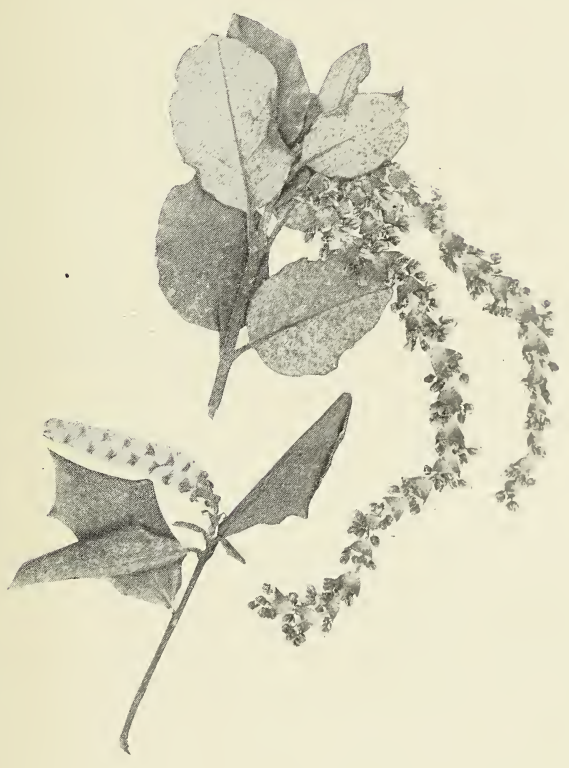

Garrya elliptica Dougl. 

De. Papers, Cal AcaD. Sci Vul. IX.

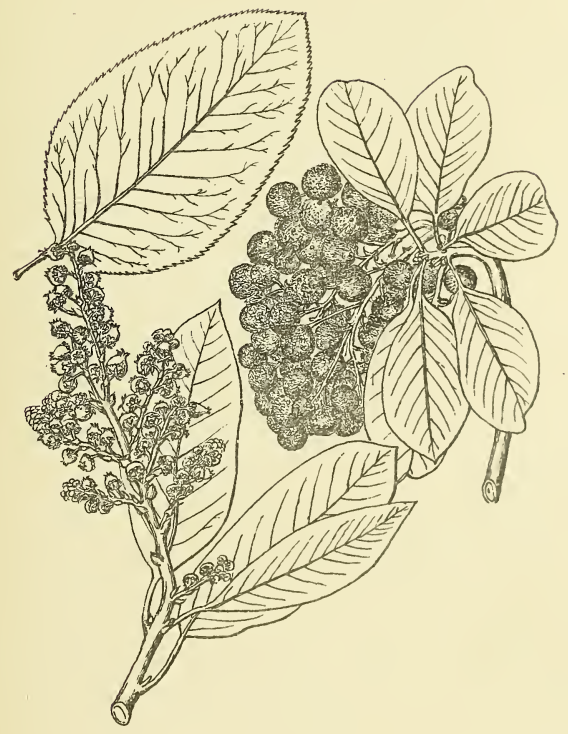



OL Papers, LAL.Acad. SEI.VIL IX

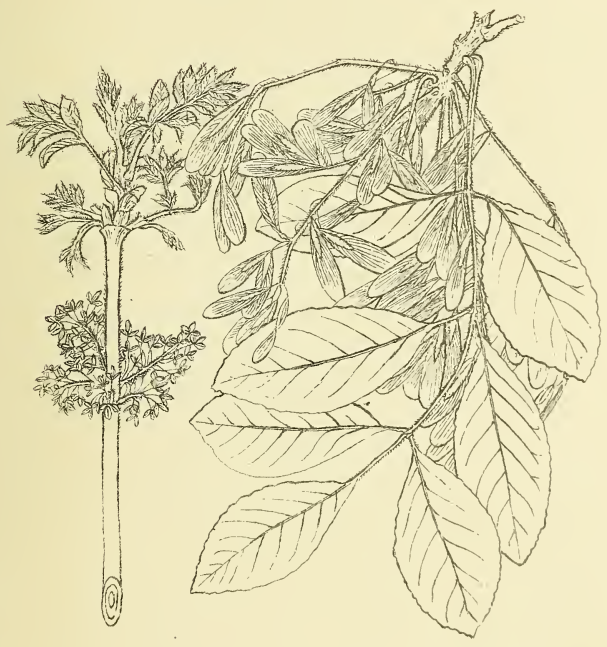

Fraxinus Oregona Nutt. 

De. Papers, Cal. Aгad. Sci.Vul. IX.

[EAstwgug]Plate W.

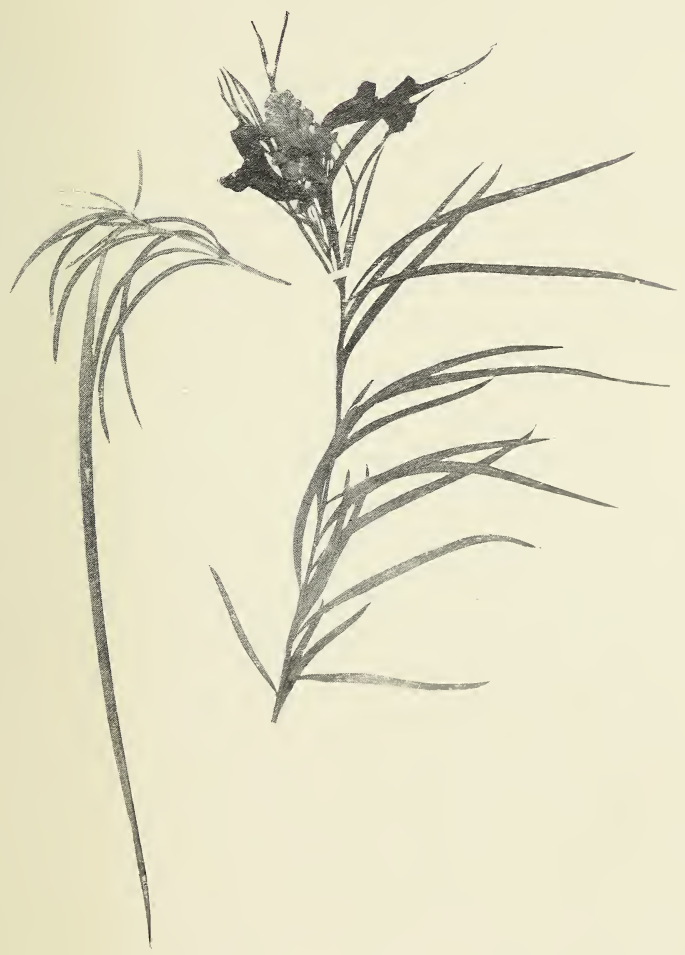

Chilopsis saligna Don. 

Dc. Paperg, [al Aca]. Sci Vul. IX.

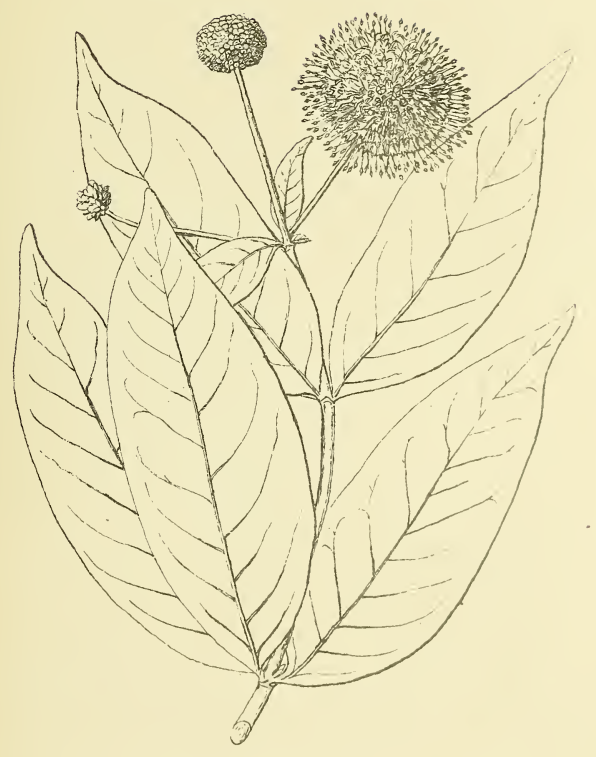

Cephalanthus ocridentalis $\mathbf{L}$ 



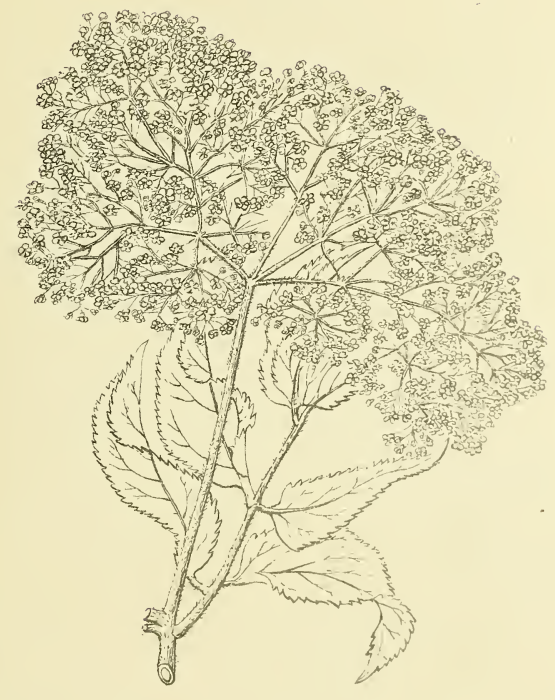





\section{INDEX AND GLOSSARY.}

New names are given in black-faced type.

ABIES AMABILIS................................... 21

bracteata..................................... 22

coneolor....................................... 21

Lowiana ................................ 21

grandis......................................... 21

lasiocarpa...................................... 21

Lowiana ...................................... 21

magnifica ......... 22

Shastensis............................ 22

nobilis ....................................... 21

venusta ................................. 22

Acacia family ..................................... 64

Acacia Greggii................................... 65

Acer circinatum ............................. 67

glabrum. ................................. 67

macrophyllum........................ 66

Negundo Californicum.................. 67

Aceraceæ............................................ 66

acuminate, narrowed to a slender point

acute, forming a sharp angle at the extremity

Esculus Californica

Alder

Algaroba.......................................... 64

Alligator-bark juniper.................... 16

Almond willow................................ 87

Alnus Oregona.................................. 44

rhombifolia ............................ 44

rubra........................................... 44

Sitchensis................................... 43

tenuifolia .............................. 41

Alpine white pine ......................... 26

Amelanchier alnifolia.................... 56

Angiosperms ................................. 32

anther, the part of the stameu that contains the pollen

Apple............................................ 56

Arbol de hierro................................. 61

Arbor-vitæ.................................... 19

arborescent, attaining the size and character of a tree

Arbutus Arizonica............................

Menziesii................................... 74

Aretostaphylos glauc ................. . 76

manzanita .............................. 75

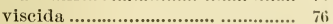

Ash family..................................... 76
Aspen.................................................. 40

axil, the angle formed between the axis and any organ arising from it, especially a leaf

axillary, in the axils of leaves or bracts

BALFOURS PINE .............................. 27

Balsam cottonwood ......................... 40

Balsam fir....................................... 21

Bay ........................................... 58

Bayberry .................................. 41

Betula fontinalis .. ......................... 43

Betulaceæ....................................... 43

Big-cone pine.................................. $\quad 29$

Big-leaved maple............................. ib

Big tree ............................................. 20

Bignoniaceæ.................................. $\quad$ i;

Birch family ................................... $4: 3$

Bishop pine...................................... 31

Bitter eherry..................................... 55

Black bireh ................................... 43

Black oak....................................., 51

Black willow........................5, 37, . 34

Blue-berried elder ........................... 79

Blue blossoms.............................70, il

Blue oak...................................... 4t; ;

Box elder ........................................... $b_{i}$

bractlet, a secondary bruct

Buckeye family............................. is

Buckthorn fanily.......................... (i?

Bull pine.......................................... .

Buttou busli......................................

Buttor willow................................ is

C ESALPINE.............................. ii

Califoruia buckeye....................... tiv

California fan palm................ . . 72

California holly.................

California laurel ......................... i . .

California lilue ...................... ;

Californi $m$ mtmeg..................... I,

Californiu penr.............. the so

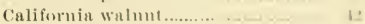

('anotia holucanthu........ is

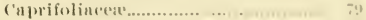

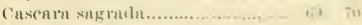

('astanopsis ehrysuphylla ....... nu w 
Cat's claw.................................... 65

Ceanothus arboreus ........................ . 71

divaricatus................................. 72

hirsutus .................................. 71

sorediatus.................................. 71

spinosus.................................... 72

thyrsiflorus. ............................. 70

velutinus lævigatus.................. 71

Cedar............................................. 16

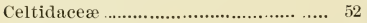

Celtis reticulata............................... 52

Cephalanthus occidentalis.............. $\quad 78$

Cerasus demissa.............................. 55

emarginata .................................. 55

ilieifolia..................................... 54

Lyoni ....................................... 54

Cercidium Torreyana ...................... 63

Cercis occidentalis .......................... 62

Cercocarpus betulæfolius.................. 58

ledifolius..................................... 58

Traskiæ....................................... 59

Chamæeyparis Lawsoniana.............. 19

Nootkatensis... ........................... 18

Cherry ............................................... 54

Chestnut oak ............................... 50

Chilopsis ....................................... 78

Chinquapin ................................ 51

Choke-cherry ..................................... 55

Christmas berry ............................. 57

Cleistoyucca arborescens. ................ 33

Coast hemlock................................. 24

Coast pine ...................................., 31

Coffee berry ..................................... 69

Coniferæ......................................... 16

cordate, heart-shaped, especially the

base of a leaf or petal

Cordyline.

Cornaceæ

Cornus Nuttallii..

sessilis

corymb, a flat-topped or open flower cluster, blooming from the outside towards the center

Cottonwood

Coulters pine

Crab-apple.

Cratægus Douglasii. rivularis

crenate, scalloped, with rounded teeth

crenulate, the teeth very small cyme, a broad and somewhat flat flower cluster in which the flowers bloom from the top or center

Cypress.

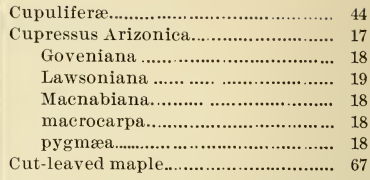

DALEA SPINOSA............................... 60

deciduous, falling in season, as leaves in autumn

dentate, with teeth on margin pointing outwards

Desert willow

Dicotyledonous plants ...................... 34

Digger pine.. ................................... 29

Dogwood family............................ $\quad 72$

Dogwood tree................................... 73

Douglas spruce ................................ 23

Dracæna ............................................ 33

Dragon palm................................. 33

ELDER ......................................... 79

elliptical, with the shape of an ellipse

Endogens.

entire, with even margin, without toothing or division

epidermis, the outside covering of leaves and stems

Ericaceæ.......................................... 74

Evergreen willow............................... 38

Exogens ....................................... 34

FALSE SLIPPERY EEM........................ 69

fascicle, a close cluster or bundle of flowers or leaves

filament, the stem of an anther

Fir.

Flowering ash 76

Foxtail pine .................................. 27

Fragrant cypress ............................. 18

Fraxinus coriacea.......................... 77

dipetala ................................... 76

Oregona .................................... 77

Fremontia ....................................... 69

Fremontodendron............................ 69

Californica.................................. 69

Fremonts cottonwood..................... 40

Fringe tree family............................ 73

GARRYA ELLIPTICA .......................... 74

Garryaceæ ...................................... 73

17 glaucous, blue-green, like a cabbage

\section{(1)}

(8)

\section{8} 19 18

8

67

(1)

(1)

(1)

3

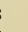

9


Golden-leaf oak.

Gray-leaf pine

Gymnosperms

HACKBERRY.

Hackberry family

Hawthorn

head, a cluster of flowers arranged

in a bunch and having no stems

Heather family

Hemlock

Heteromeles arbutifolia.

Hill oak

Hippocastanaceæ.

Holly-leaved cherry

Honey dew...

Honey mesquite

Honeysuckle family.

Hop tree

Horse-bean

INCENSE CEDAR.

inferior, said of the seed vessel when it is beneath the calyx

involuere, a cluster of bracts or small leaves at the base of a head or umbel

Island oak ...............................48,

Islay

Ironwood

JosUA TREF.

Judas tree.

Juglandaceæ

Juglans Californica. rupestris.

Juniper.

uniperus Californica..................... 17

monosperma............................ 16

occidentalis... ........................... 17

pachyphlæa............................... 16

scopulorum............................... 16

Utahensis ................................ 17

KELLOGGS OAK.............................. 45

Knob-cone pine.............................. 30

LARCH

Large flowered dogwood ................. 73

Larix Lyallii.................................... 23 occidentalis................................ $2: 3$

La uraceæ... .................................. $55_{2}^{2}$

Laurel family.................................. 52

Lawsons eypress.............................. 18
Lemon family................................ 65

Libocedrus decurrens .................... $\quad 20$

Liliaceæ.......................................... 33

Lily family..................................... . 33

linear, narrow, several times longer

than wide

Little sugar pine ........................... 26

Live oak.......................................4 $46, \quad 49$

lobe, any division of an organ, especially a rounded division

Lodge pole pine............................... 31

Lyorothamnus asplenifolius........... 59 floribundus . ............................. 59

MADDER FAMILY $\ldots \ldots \ldots \ldots \ldots \ldots \ldots \ldots \ldots \ldots$ is

Madrone.............................................. if

Madroño .......................................... it

Malus rivularis ............................... 56

Manzanita ..................................... 75

Maple family .................................... $66^{\circ}$

Maul oak .......................................... 49

Mendocino eypress.......................... 18

midrib, the central vein of a leaf or other organ

Mimoseæ........................................ 64

Monocotyledonous plants................. 32

Monterey eypress............................. 18

Monterey pine .............................2 $6, \quad 30$

Mountain eypress ............................. 1s

Mountain mahogany........................ 58

Mountain maple............................ it

Mountain pine................................. 20

Mountain white oak.......................

mucronate, with a sharp terminal point

Myrica Californiea .......................... 41

Hartwegi..................................... $4: 3$

Myricaceæ................................... 41

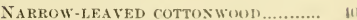

Nut pine......................................24.

OAk............................................ I

Oak family ..................................... if

oblanceolate, shaped liken lanee lut with the broul part at (op)

oblong, much louger than lorond, with nearly purallel silles

obovate, with the ontline of $n 11$ igg. the bronder purt on toj

obtuse, blant or poumbel at the and

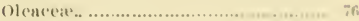

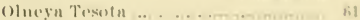

One-lenverl pine ........ ..... . . . .... on

orbicular, with u cireulur muthus 
Oregon ash

Oregon pine.

oval, in the shape of a broad ellipse

ovary, that part of a pistil that con-

tains the young seeds

ovate, with the outline of an egg, the broader end down

ovule, an immature seed in the ovary

PACIFIC YEW

Pale willow.

Palm family

palmate, lobed or veined from the

base with the lobes or veins diverg-

ing

Palmæ

Palo verde

panicle, a compound flower cluster

Papilionaceæ..

Parkinsonia aculeata.

microphylla

Torreyana..

Parrys nut pine.

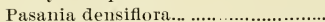

Patton spruce.

Pea family.

Peach willow.

pedicel, the stem of a flower in a cluster

peduncle, the main stem of a flower cluster

Pepper-wood...

perfect, applied to flowers when they contain both pistil and stamens

perianth, the floral envelopes, calyx or corolla or both

petiole, the stem of a leaf

Picea Breweriana

Engelmanni

Sitchensis.

pinnate, lobed or veined from the axis to the margin, generally parallel

Pine family

Piñon.

Pinus albicaulis

aristata

A rizonica.................................. 25

attenuata .................................... 30

Balfouriana............................... 27

Chihuahuana ........................... 28

contorta. ...................................... 30

Coulteri.................................... 29

edulis ......................................... 28

flexilis ...................................... 26
Pinus insignis............................. 30

Jeff reyi...................................... $\quad 29$

Lambertiana ............................. 26

latifolia ..................................... 29

monophylla.............................. 28

monticola................................... $\quad 26$

muricata................................. 31

Murrayana........ .................. . 31

Parryana ..................................... 28

ponderosa .................................. 28

quadrifolia................................. 28

radiata.................................... 30

Sabiniana................................. $\quad 29$

Torreyana................................. $\quad 27$

tuberculata................................ 30

pistil, the female organ of a flower

Plane tree.......................................... 53

Platanaceæ.................................. 53

Platanus racemosa........................... 53

Plum........................................... 55

Poplar. .......................................... 40

Populus angustifolia ...................... 40

balsamifera................................. 40

Fremontii ................................ 41

Mexicana.................................. 40

tremuloides .............................. 40

trichocarpa............................... 40

Port Orford cedar.......................... 18

Prosopis juliflora............................ 64 pubescens .................................. 64

Prunus integrifolia............................ 55 subcordata................................ 55

Kelloggii ........................... 56

Pseudotsuga Douglasii .................22, 23 macrocarpa ................................ 23

mueronata .................................... 23

taxifolia................................... 23

Ptelea crenulata.............................. 66

pubescent, clothed with soft hair or down

Pyrus rivularis ............................. 56

QUERCUS AGRIFOLIA........................ 46

Alvordiana ................................. 48

A rizonica................................ 50

Californica................................. 45

chrysolepis................................. 49

densiflora................................ 50

Douglasii ................................... 48

Emoryi ................................... 51

Engelmanni .............................. 49

Gambellii.................................. 50

Garryana.................................. 47

hypoleuca................................ 51

lobata ...................................... 47 
Quercus Macdonaldi.

Morehus

oblongifolia.

reticulata.

tomentella

Tuomeyi.

undulata...

Wislizeni

Quinine bush

RACEME, a cluster of flowers with equal stems on a lengthened axis, blooming from the base up

receptacle, the organ on which the parts of a flower are placed, or the flowers themselves when in a head

Red alder..

Red-berried elder.

Red-bud.

Red cedar.

Red fir.

Redwood.:

regular, uniform, when applied to the divisions of the floral organs

Retama.

revolute, with the edges rolled back

Rhamnaceæ

Rhamnus insularis........................... 70 pirifolia.................................... 70

Purshiana.................................. 70

Roble

Rosaceæ.......................................... 54

Rose family ...................................... 54

Rubiaceæ..................................... 78

Rutaceæ.......................................... 65

SALICACE $\not$......................................... 34

Salix amygdaloides............................ 37 Bonplandiana ............................ 38

fluviatilis.................................. 37

Hookeriana................................ 39

lævigata...................................... 37

lasiandra................................... 38

lasiolepis................................... 38

Mackenziana................................ 36

nigra.......................................... 35

vallicola................................ 36

Nuttallii brach ystach ys................. 39

occidentalis................................. 36

sessilifolia ................................. 37

Sitchensis..................................... 39

taxifolia .................................... 38

Sambucus callicarpa........................ 79

glauca... ..................................... 79

Saud-bar willow .............................. 37

Santa Lucia fir............................... 22
Screw bean..................................... 64

Scrub pine......................................... 30

Senna family.................................... 61

Sequoia gigantea............................... 20

sempervirens................................ 20

Wellingtonia................................ 20

serrate, edged with upwardly pointing teeth

serrulate, diminutive of servate

Service berry................................ 56

Sierra hemlock............................... 24

Sierra plum....................................... 56

Silk-tassel bush.............................. 74

Silver fir .......................................... 22

Slippery elm.................................. 69

Spanish bayonet............................... 33

Spanish dagger................................. 38

spatulate, short-oblong, but uarrowed to the base

Spice wood

spike, an elongated flower cluster blooming from the base up, with stems to the flowers very short or wanting

Spruce.

staminodium, a sterile or nbortive stamen without an anther

stellate, star-shaped

Sterculia family.

Sterculiaceæ.... ............................... (i?

sterile, barreu, as a flower without a pistil, or a stamen without the anther

stigma, the top of the pistil where the pollen falls to fertilize the secils stipule, an appendage at the base of a leaf stalk

Sugar berry

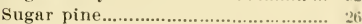

Sycamore fumily........................... 5,3

TAMARACK.

Tamarack pine ................................ :

Tun bark onk.................................... (n)

Tахасеве ......................................... 15

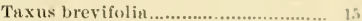

Thorn apple .................................. is

Thuy gigunten............................. 19 plicata .................................... 1?

thy rse, a coutracted or ovele pmuicle or close complominl cluster

Tiek trec........................................ तो

Tideland spruee ................................. 21

tomentose, densely clotlacal with matted wool or stort hair 
Torrey pine

Torreya.

Californica

Toyon

Tree yucea...

Trumpet-vine family

Tsuga heterophylla.

Mertensiana

Pattoniana

tubular, with the shape of a hollow eylinder

Tumion Californicum

UMBEI, a flower cluster with the stems all arising from the same disk, blooming from the outside

Umbellularia Californica

Uña de Gato

VALLEY OAK.

Vauquelinia Californica

Velvet willow.
Vine maple

WALNUT FAMILY

42

Washington palm.......................... 32

Washingtonia filamentosa................ 32

Wax-myrtle family.......................... 41

Weeping oak..................................... 47

Weeping spruce................................. 25

White fir....................................... 21

White live oak ................................... 49

White oak ..............................47, 48, 50

White pine ................................... 26

White willow .................................. 38

Wild plum ....................................... $5 \tilde{c}$

Willow family............................... 34

YELLOW PINE.................................25, 28

Yew family..................................... 15

Yew-leaved willow ........................... 38

Yosemite oak................................... 45

Yucca Mohavensis.......................... 33

Yuceeæ.......................................... 33 





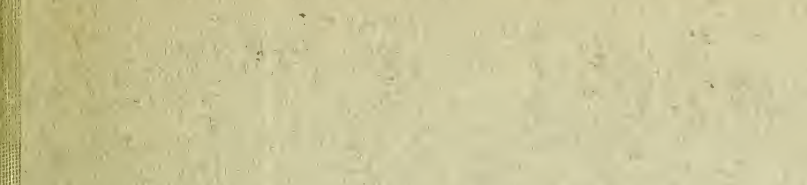


